البصيرة: مجلة الدراسات الإسلامية

AL-BASHIRAH: JOURNAL OF ISLAMIC STUDIES

Vol. 2 No. 1 (2021): 1-48

Website: https://journal.stiba.ac.id

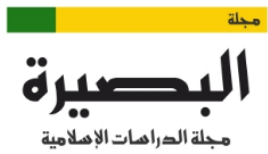

AL-BASHIRAH

\title{
قواعد النيات والمقاصد عند الحافظ العراقي وابنه الحافظ أبي زرعة \\ من خلال كتابمما "طرح الثثريب"
}

\section{محمد إحسان}

المعهد العالي للدراسات الإسلامية و اللغة العربية، ماكسر إلاكس

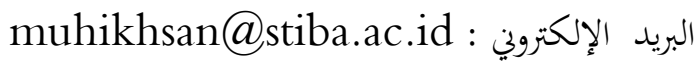

\section{حساني محمد نور}

كلية العلوم الإسلامية، جامعة المدينة العالمية، ماليزيا

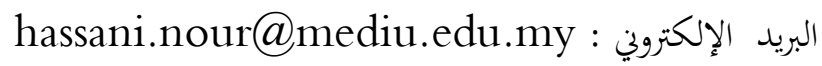

\section{المستخلص}

هذا البحث يهدف إلى استخراج القواعد الضابطة لمقاصد المكلفين ونياتم عند الحمافظ العراقي في كتابه "طرح التثريب".

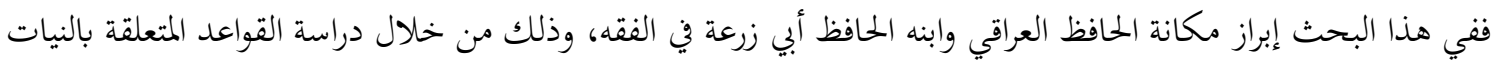

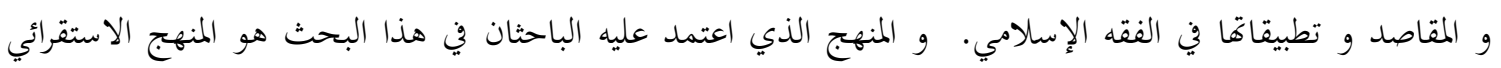

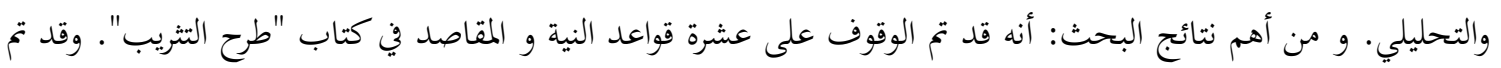

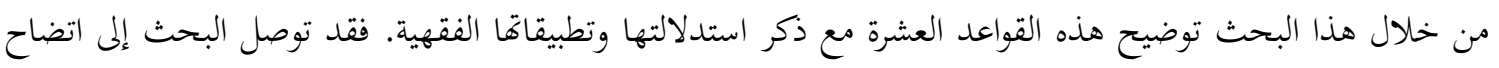

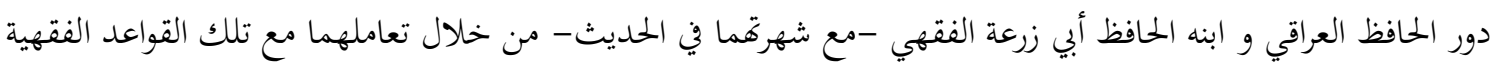

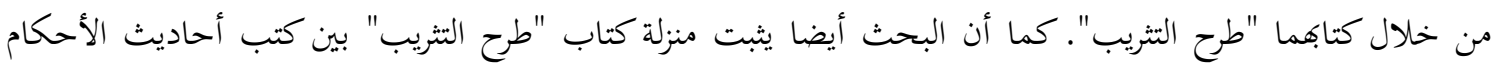

$$
\text { الشهيرة. }
$$

الكلمة المفتاحية: الحافظ العراقي, طرح التثريب, القواعد، المقاصد، النية. 
Website: https://journal.stiba.ac.id TATSRIB" BY AL-HAFIZH AL-IRAQI AND HIS SON, AL-HAFIZH ABU ZUR'AH

\author{
Muhammad Ikhsan \\ Sekolah Tinggi Ilmu Islam dan Bahasa Arab, Makassar \\ Email : muhikhsan@stiba.ac.id \\ Hassani Mohammed Nour \\ Al-Madinah International University (MEDIU), Malaysia \\ Email : hassani.nour@mediu.edu.my
}

\begin{abstract}
This study aims to explore the principles of the Islamic law that govern the intentions and intentions of the mukallaf in the views of al-Hafizh al-Iraqi and his son, al-Hafizh Abu Zur'ah, in their work, Tharh alTatsrib. This research seeks to raise the position of al-Hafizh al-Iraqi and his son, al-Hafizh Abu Zur'ah, in the study of Islamic law, through a study of fiqh principles relating to the intention of mukallaf and their application in Islamic law. The method used in this research is the inductive method and legal analysis. Among the important conclusions of this research is that there are at least 10 rules related to intention in the Book of Tharh al-Tatsrib, all of which are then explained the arguments and applications of Islamic law. This research also found the superiority of al-Hafizh al-Iraqy and his son, al-Hafizh Abu Zur'ah, in the study of Islamic law, although both were more popular in the study of hadith; which is shown by their interaction with the rules of Islamic law in their work, Tharh al-Tatsrib.
\end{abstract}

Keywords: al-Hafizh al-'Iraqy, tharh al-Tatsrib, Qawa'id Fiqhiyyah, maqashid, intention.

المقدمة

القواعد الفقهية من أهم الثروات العلمية الفقهية. فالفقه علم ذو فروع متناثرة يصعب ضبطها و

حصرها. وهذه الفروع تتزايد مع تعاقب العصور وتطور الحاجات البشرية في مختلف الأزمان. فمن هذا المنطلق، جاء دور القواعد الفقهية في اشتمال هذه الفروع و حصرها تحت كنفها لتلخص الأحكام الأحكام اللازمة للمكلفين في تلك الفروع.

فلذلك، كان اتساع دائرة القواعد الفقهية تابعة لاتساع دائرة المباحث الفقهية. بل دخلت في كل

باب من الأبواب الفقهية تحت مسمى "الضوابط الفقهية"؛ و هي تلعب نفس الدور للقواعد الفقهية في دائرة

أضيق منها. و في تأكيد أهمية معرفة هذه القواعد، قال الزركشي -رحمه الله- و هو يعدد أنواع الفقه-:

"...معرفة الضوابط التي بتمع جموعا والقواعد التي ترد إليها أصولا وفروعا وهذا أنفعها وأعمها وأكملها وأتمها تركا

$$
\text { وبه يرتقي الفقيه إلى الاستعداد لمراتب الجهاد(1) وهو أصول الفقه على الحقيقة"(؟). }
$$$$
\text { (1) هكذا في الأصل، و لعل الصواب: (الاجتهاد)، و الله أعلم. }
$$

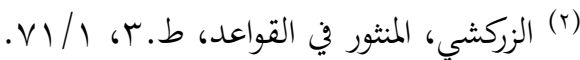


البصيرة: مجلة الدر اسات الإسلامية

AL-BASHIRAH: JOURNAL OF ISLAMIC STUDIES

Vol. 2 No. 1 (2021): 1-48

Website: https://journal.stiba.ac.id

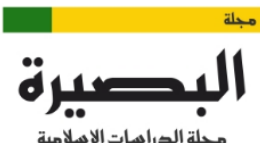

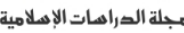

AL-BASHIRAH

و من أهم مجالات تطبيق القواعد الفقهية و توظيفها هو مجال النيات و مقاصد المكلفين. فالنية و

المقصد منبع عمل المكلف. و عليها يدور قبوله أم رده عند الله. فلذلك كان اهتمام العباد الصالحين يرتكز

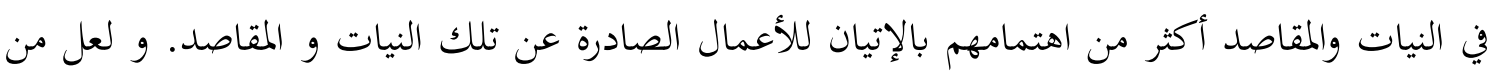

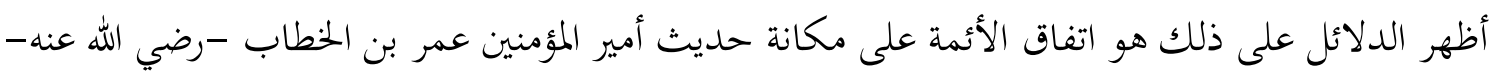

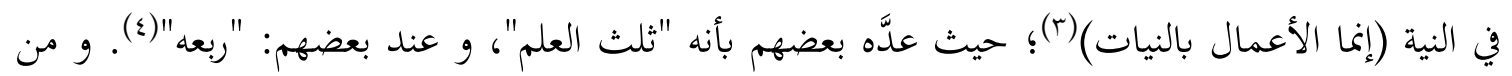

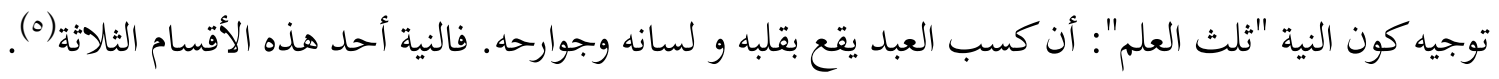

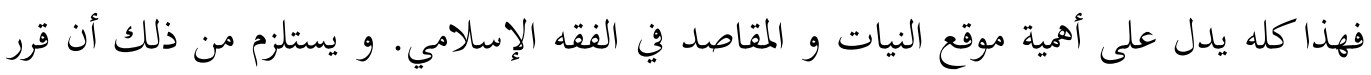

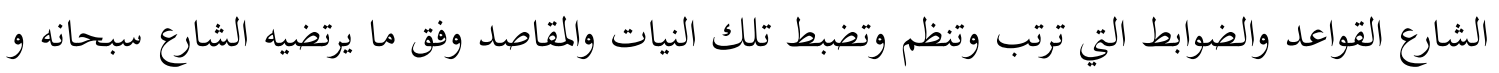

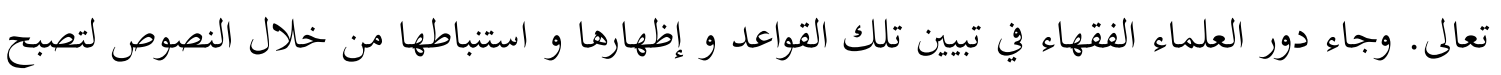
منهجا واضحا للأمة في ضبط كل المسائل والقضايا والأعمال المرتبطة بنياتم وقصدهم.

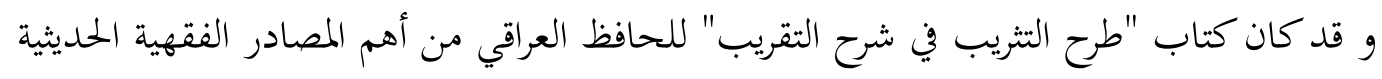

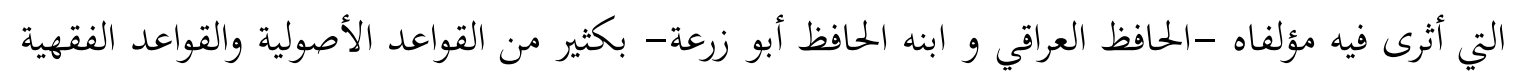

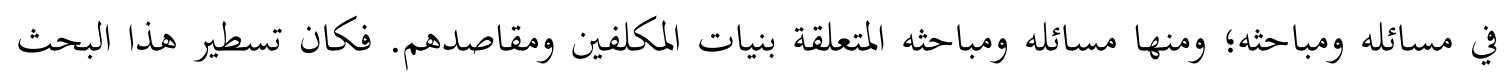
من أجل جمع تلك القواعد المتعلقة بالنيات والمقاصد ودراستها. تدور أهمية هذا البحث مع أهمية موقع النية و المقاصد في الشريعة الإسلامية - كما تقدم-. فالنيات والنية

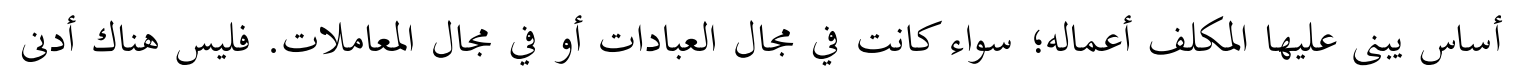

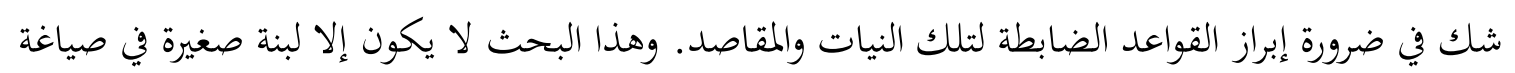
القواعد والضوابط التي تتعلق بتصحيح النيات والمقاصد وتعديلها عند المكلفين.

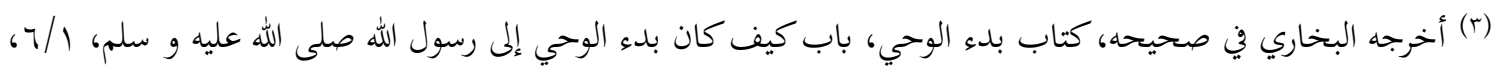

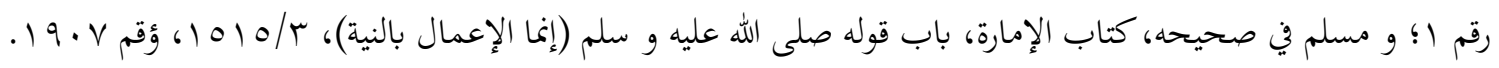

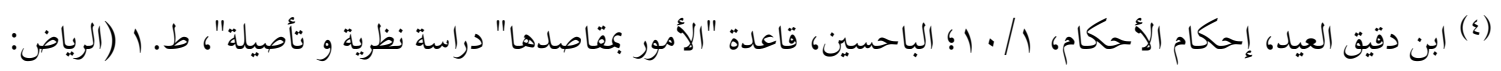

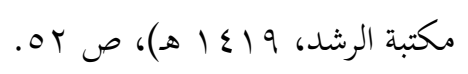$$
\text { (o) (الباحسين، المرجع نفسه. }
$$ 
تظهر إشكالية البحث في أن الحافظ العراقي وابنه الحافظ أبي زرعة مع سعة باعهما في الفقه والأصول -وقد صنفا فيهما مصنفات مفيدة-، إلا أننا لم نقف على مصنفاقما الخاصة بالقواعد الفقهية مع وفرة

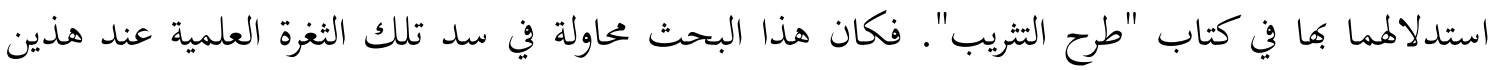

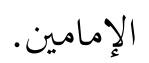

و على هذا، جاءت أسئلة البحث الآتية:

1 - - من الحافظ العراقي و ابنه الحافظ أبي زرعة و ما قيمة كتاب "طرح التثريب"؟

r - ب ما منزلة النية و المقاصد في الفقه الإسلامي؟

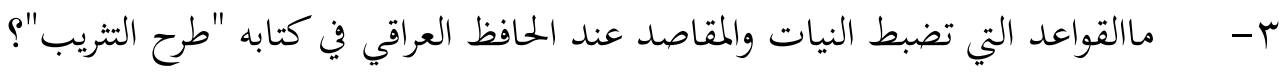
وبناء على تلك الأسئلة، فكانت أهداف هذا البحث هي: البئ 1 - - تعريف موجز و مختصر عن الحافظ العراقي و ابنه الحافظ أبي زرعة و كتاهما "طرح التثريب". r ب بيان منزلة النية و المقاصد في الفقه الإسلامي. r- - ذ ذكر قواعد النيات و المقاصد عند الحافظ العراقي و الحافظ أبي زرعة في كتابهما "طرح

$$
\text { التثريب" مع شرح موجز لها و إيراد التطبيقات عليها. }
$$

اقتضت طبيعة البحث أن يعتمد على المنهج الاستقرائي والتحليلي. فقام الباحث باستقراء القوراعد

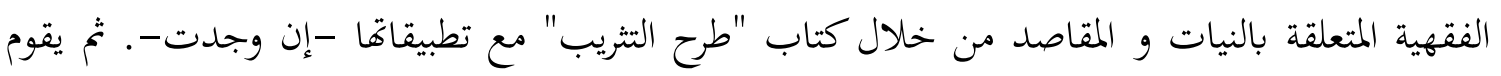
الباحث بتحليل تلك القواعد المجموعة من حيث اللغة و الاصطلاح و الفقهي -بذكر كلام العلماء ومباحثاقم تهنم

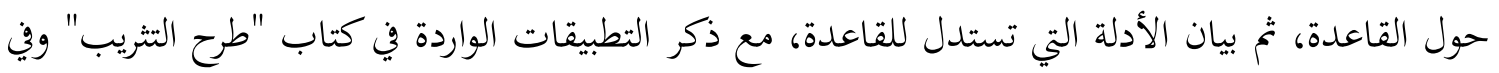

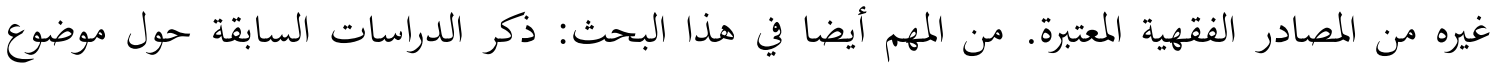

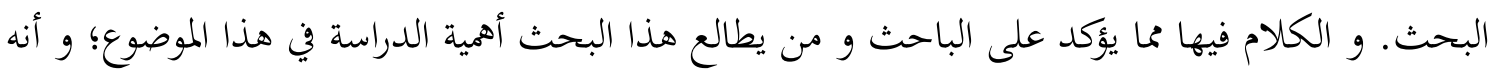
- فعلا- هناك ثغرة علمية بحاجة إلى سدها و الغوص فيه لتتكامل بينان العلم بها.

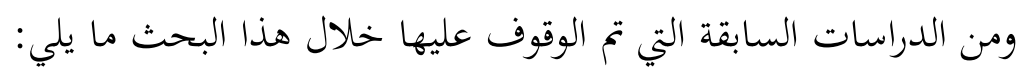

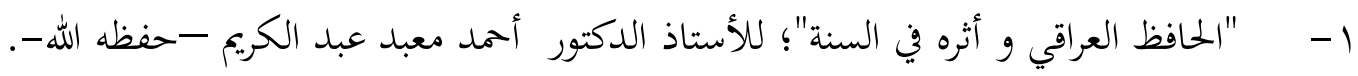

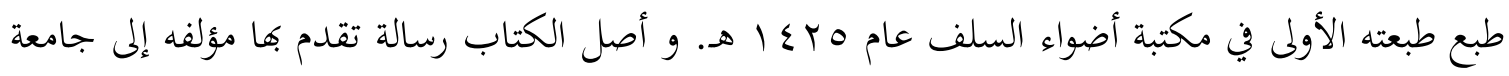

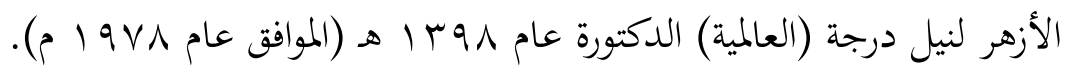


ץ- - "الأراء الأصــــلية في الأمر و النهي و العام و الخاص للحافظ العراقي و ابنه في كتابهما

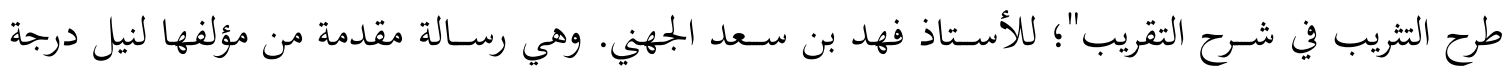

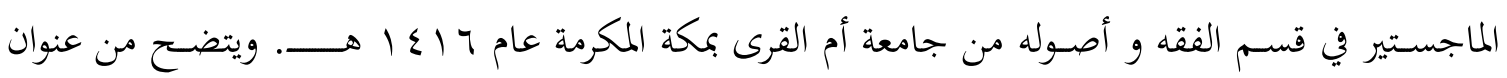

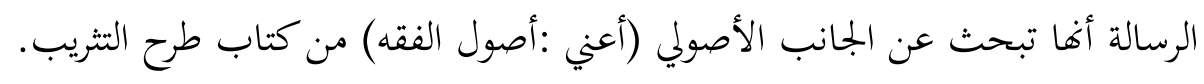

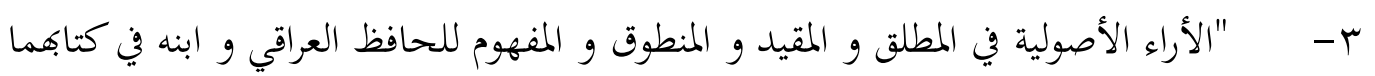

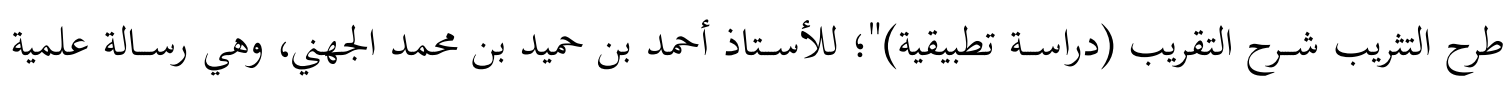

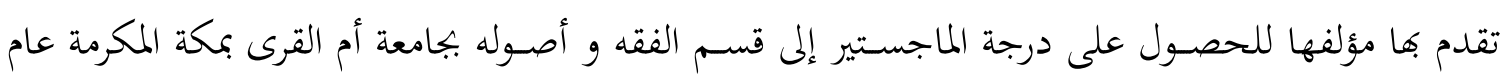

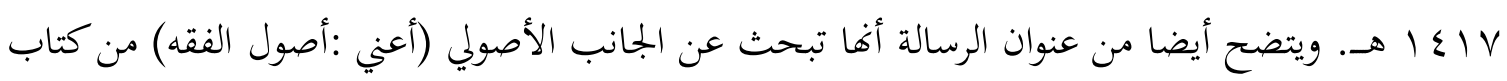
طرح الثثريب. ع - "الأمنية في إدراك النية"، للإمام أبي العباس أحمد بن إدريس القرافي (ت ع بش هـ). و هي

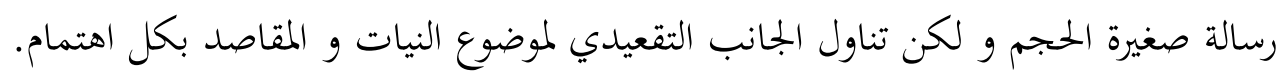

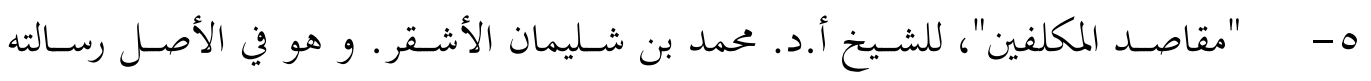
المقدمة لنيل درجة الدكتوراة في جامعة الأزهر. و ولعله من أوفي الكتب المعاصرة كلاما في موضوع المقاصد.

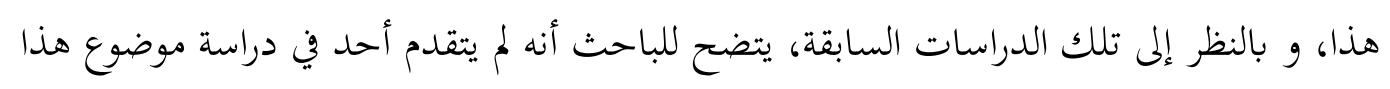

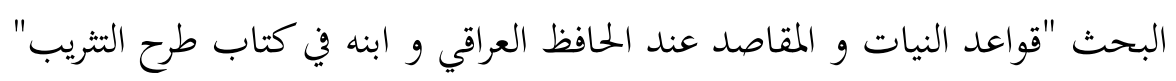

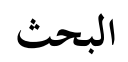
تعريف موجز عن الحافظ العراقي و ابنه أبي زرعة و كتاجما "طرح التثريب":

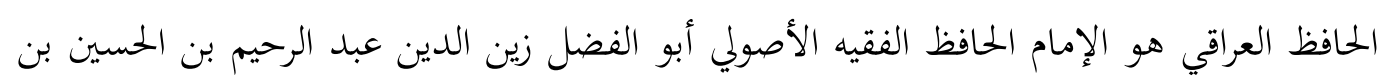

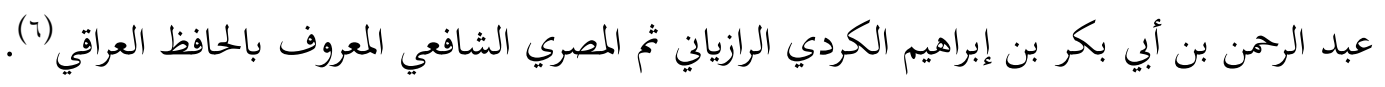

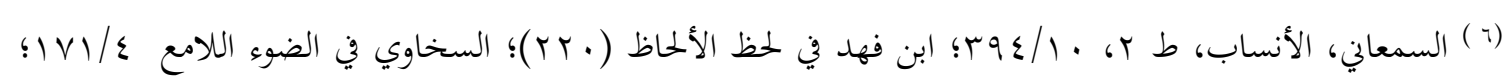

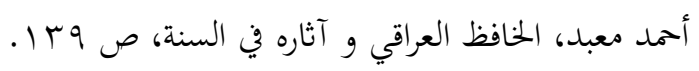


البصيرة: مجلة الدر اسات الإسلامية

AL-BASHIRAH: JOURNAL OF ISLAMIC STUDIES

Vol. 2 No. 1 (2021): 1-48

Website: https://journal.stiba.ac.id

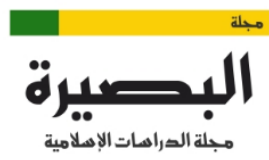

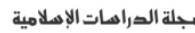

AL-BASHIRAH

ولد الحافظ العراقي رممه الله في الحادي و العشرون من جمادى الأولى سنة VYO هـ بمنشأة المهراني

على شاطئ النيل بين مصر و القاهرة(v).

تصدر الحافظ العراقي رمه الله التدريس و الإملاء في عدد من المدارس و المجالس العلمية. و قد برع المعاد

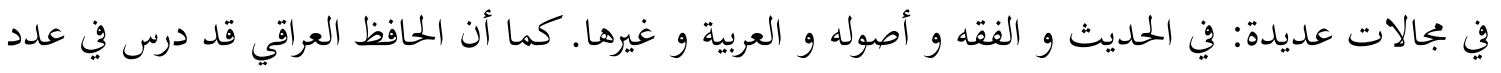

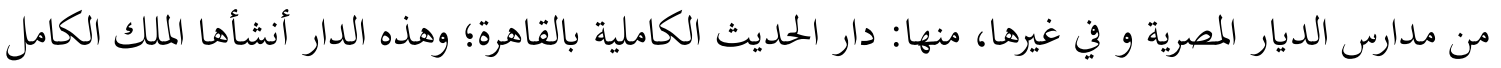

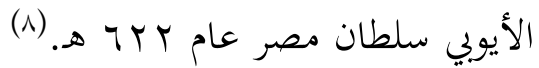

فقد تتلمذ على الحافظ العراقي رمه الله كثيرون من أجلة العلماء مع اختلاف مذاهبهم و مشاربهم. (9. أما المناصب التى توليها الحافظ العراقي رمه الله غير منصب التدريس الذي ذكرناه، فقد كان رحمه الله يتولى وظيفة الإملاء في بجالس الحديث النبوي. بل يعتبر الحافظ العراقي ممن يجدد هذه المهمة التي اندثرت بعد عهد

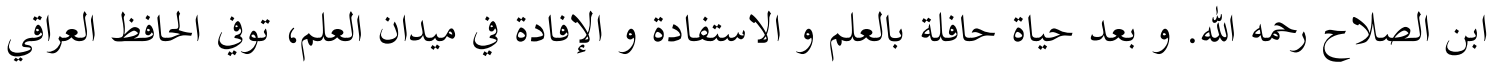

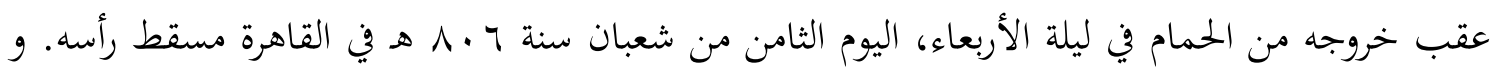

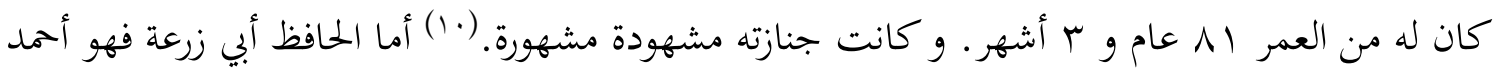

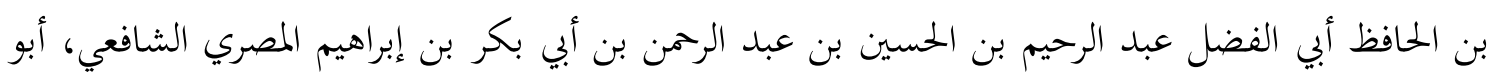
زرعة ولي الدين العراقي (11).

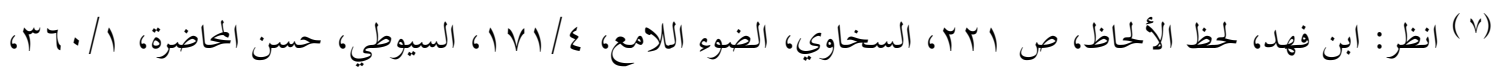

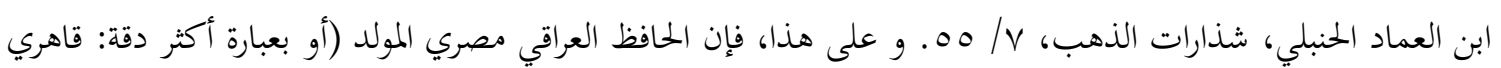

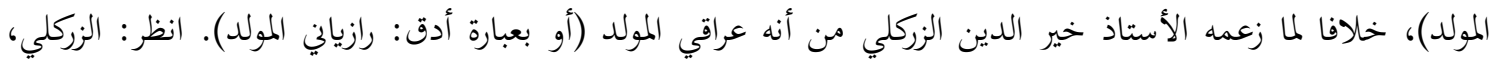

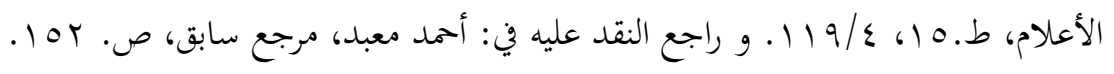

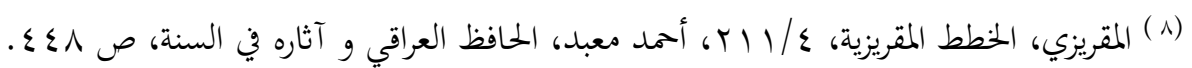

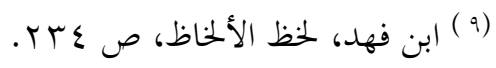

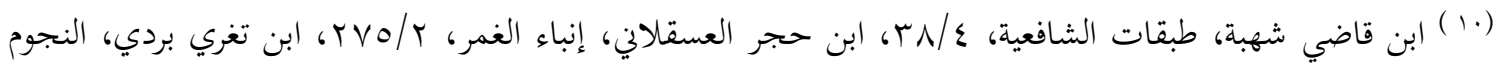

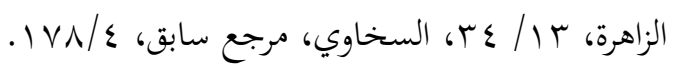

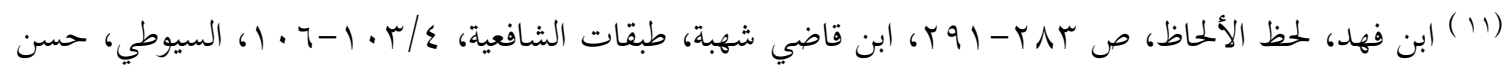

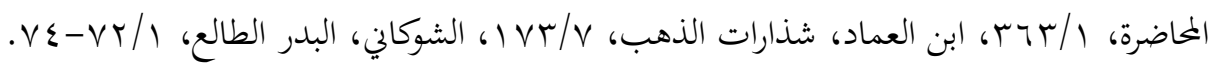


البصيرة: مجلة الدر اسات الإسلامية

AL-BASHIRAH: JOURNAL OF ISLAMIC STUDIES

Vol. 2 No. 1 (2021): 1-48

Website: https://journal.stiba.ac.id

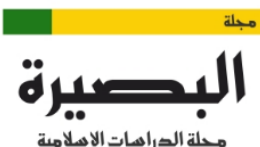

مجلة الصراهات الإهلامية

AL-BASHIRAH

ولد الحافظ أبو زرعة بظاهر القاهرة في اليوم الثالث من شهر ذي الحجة، بعد صلاة الفجر من سنة

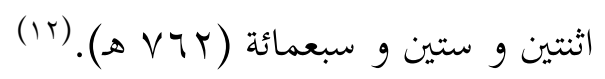

اعتنى به والده الحافظ أبو الفضل العراقي منذ نعومة أظفاره أشد الاعتناء. فبكّر به والده إلى مجالس

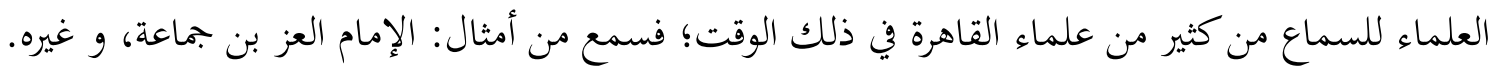

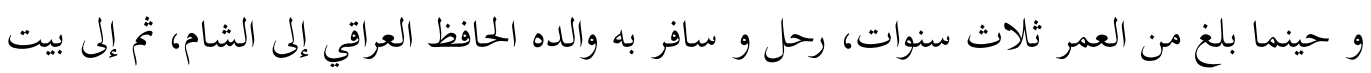

المقدس، فحضر في عدد من المجالس العلمية، و استحصل له والده الإجازات العلمية من العلماء الشاميين.

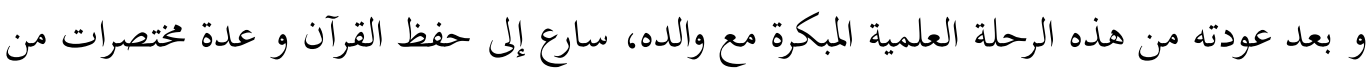

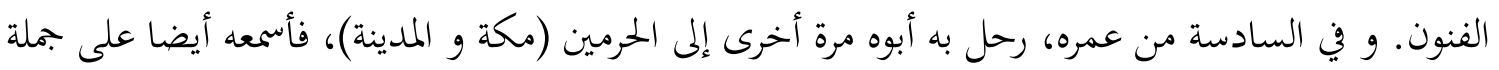

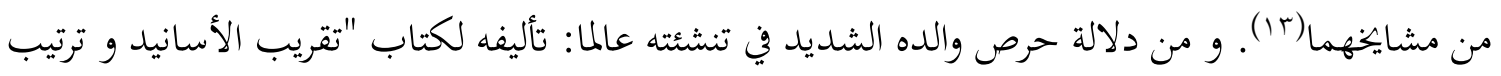

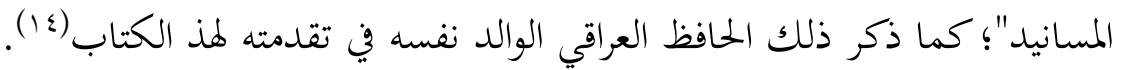

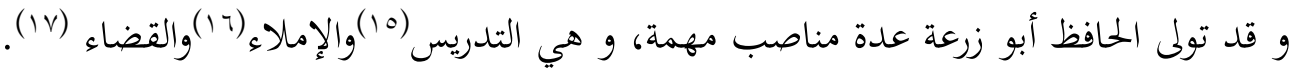

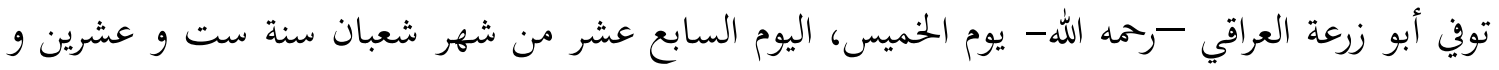

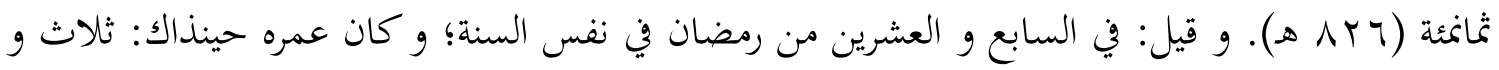
ستون سنة و ثمانية أشهر (1) (1).

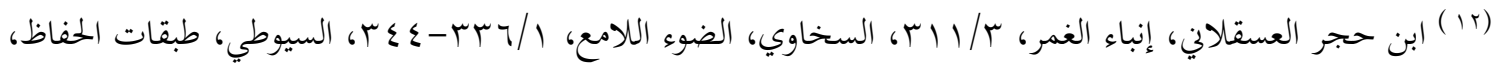
$.0 \leqslant \Lambda ص$

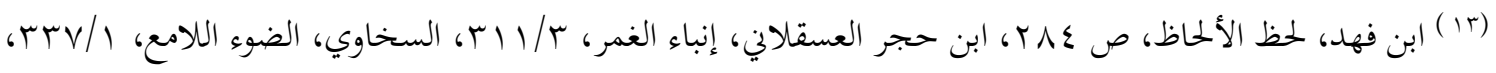

$$
\begin{aligned}
& \text { الشوكاني، البدر الطالع، VT// }
\end{aligned}
$$

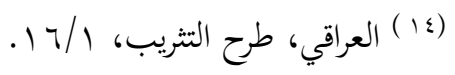

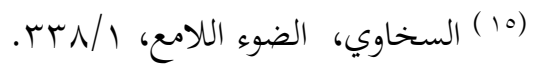

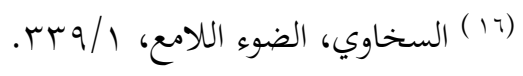

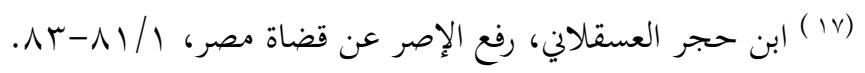

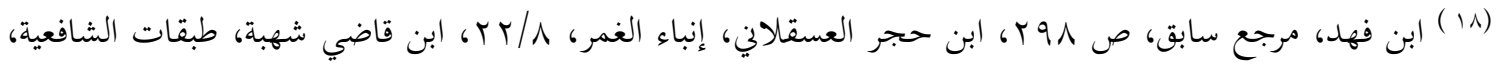

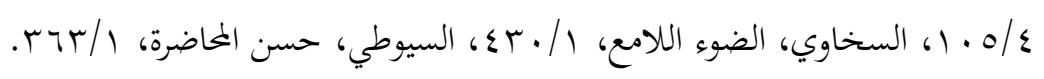


أما كتاب "طرح التثريب بشرح التقريب" - كما اتضح من عنوانه-شرح لمتن حديثي ألّفه الحافظ أبو

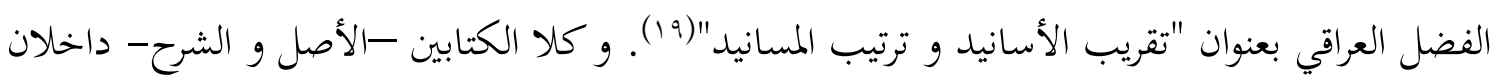
من ضمن كتب أحاديث الأحكام. و هذا النوع من التدوين اهتم به علماء الحديث قديما ومرافق لمراحل تدوين السنة النبوية. و قد كان تدوين السنة وتصنيفها إما على طريقة المسانيد أو المعاجم أو السنن.

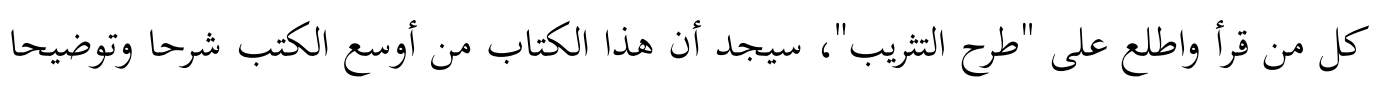

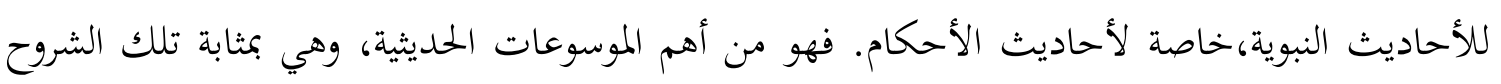

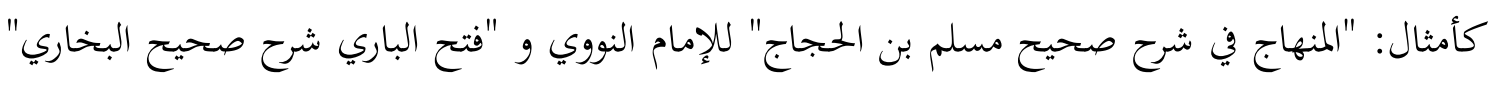

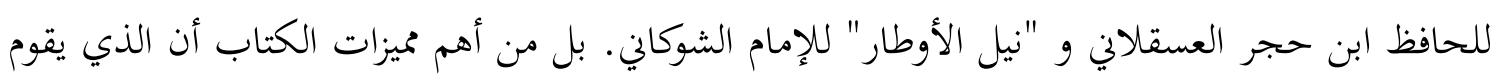

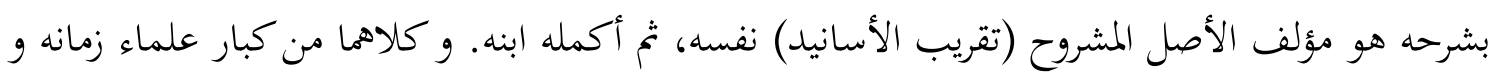
حفاظه؛ و هذه ميزة أخرى.

أما إثبات صحة نسبة الكتاب إلى الحافظ العراقي وابنه، فقد وردت عدة بيانات وتصريحات من

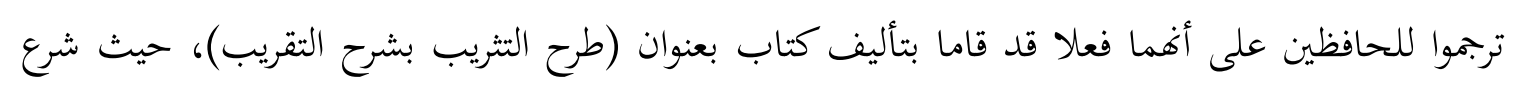

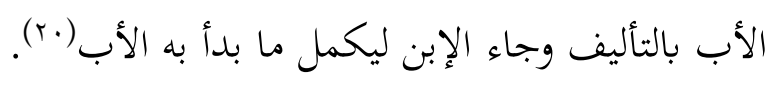
هذا، يثبت يقينا نسبة هذا الكتاب (طرح الثريب) للحافظ أبي الفضل و الحافظ أبي زرعة العراقيين.

\section{منزلة النية و المقاصد في الشريعة الإسلامية:}

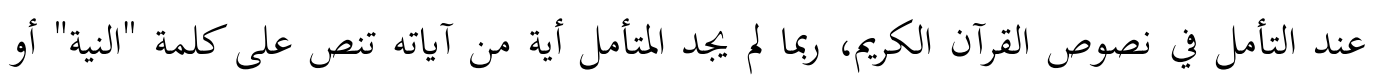

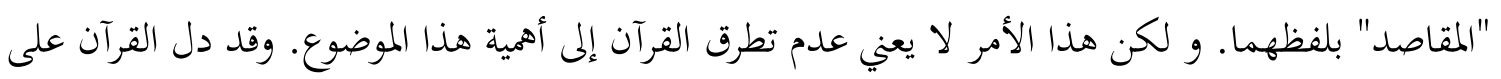

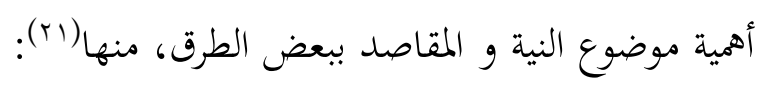

(19) طبع قديما مستقلا عن الشرح في دار الكتب العلمية البيروتية (عام ع ـــا هـ). ثم أصدرت -مؤخرا- دار المؤيد في

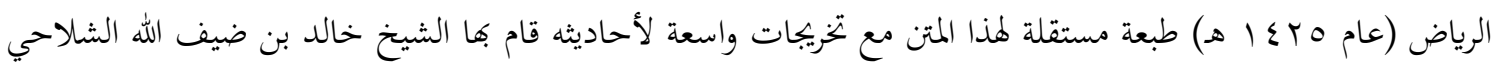

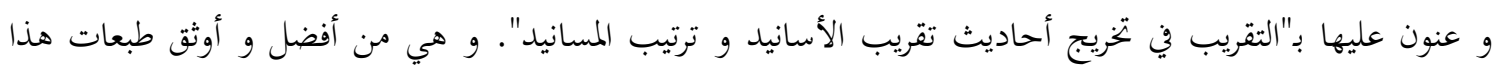
الكتاب، إن شاء الله.

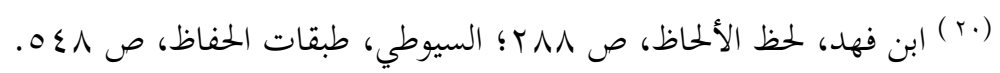

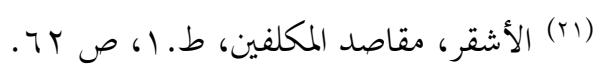


الأولى: بالتحدث عن "الإرادة" و آثارها على حياة الإنسان في الدنيا و الآخرة. كقوله تعالى: (مِنْكُمْ

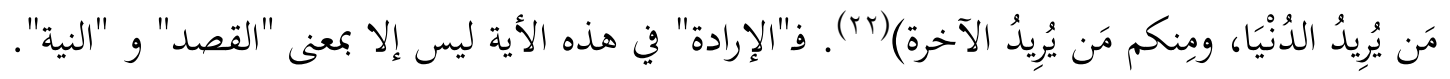

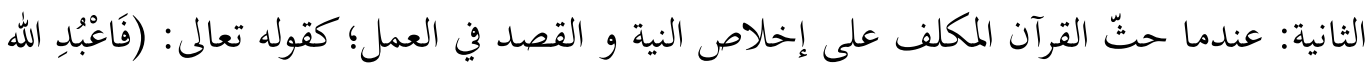

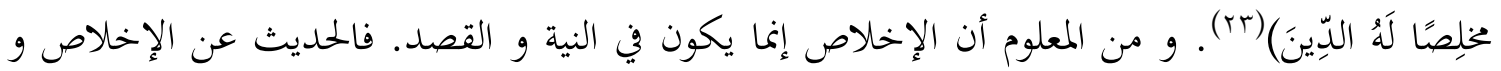
التجرد القبلي حديث عن النيات و المقاصد.

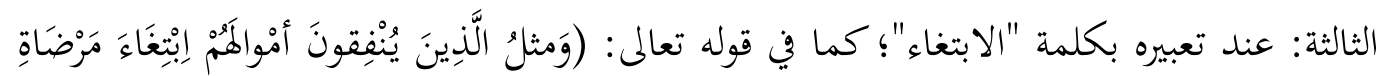

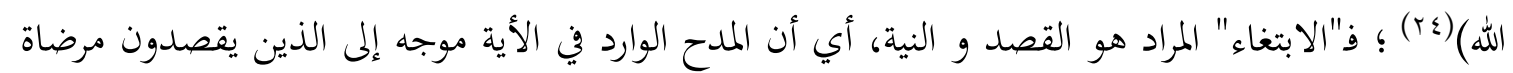
الله في إنفاقهم أمواهم. الرابعة: عند ذكر الإخلاص و لزومه في العمل، و الإخلاص لا لايكون إلا في القصد و النية، كما في قوله

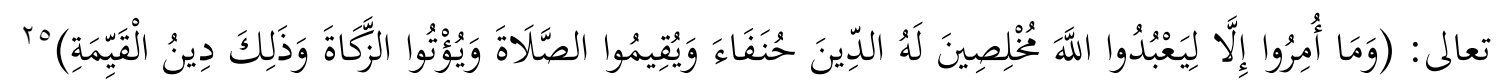

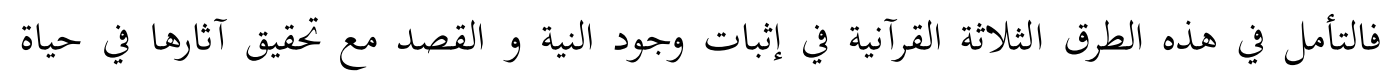
المكلف الدنيوية و الأخروية مما يدل على مكانتها و ضرورة فئا في الشريعة الإسلامية.

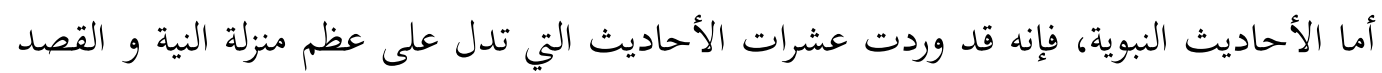

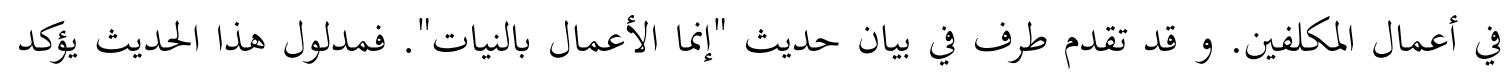

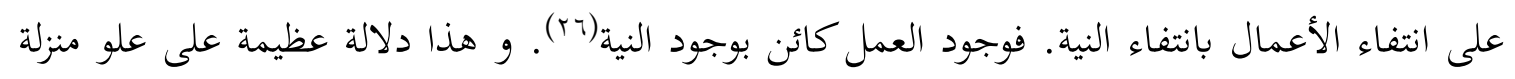
النية والقصد في الشريعة الإسلامية. و تتلخص هذه المنزلة للنية و القصد في الشريعة الإسلامية في النقاط الآتية(Y)):

$$
\begin{aligned}
& \text { (r) سورة آل عمران، جزء من الأية ror) }
\end{aligned}
$$

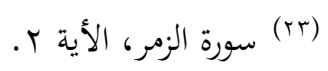

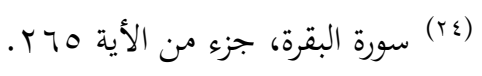

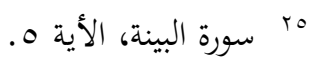

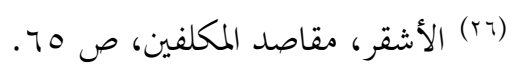

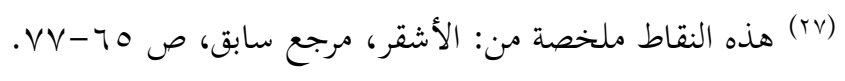


البصيرة: مجلة الدر اسات الإسلامية

AL-BASHIRAH: JOURNAL OF ISLAMIC STUDIES

Vol. 2 No. 1 (2021): 1-48

Website: https://journal.stiba.ac.id

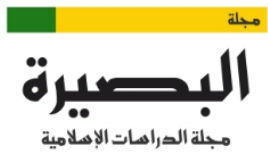

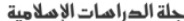

AL-BASHIRAH

1 - مما يدل على اعتبار القصود في العبادات والتصرفات أن الأفعال الاختيارية لا تصدر من الإنسان إلا بقصد وإرادة. ولو كلف العباد أن يعملوا عملا بغير نيّة كلفوا ما لا يستطيعون. r - أن الأعمال الصادرة عن غير قصد و نية؛ فهي غير معتبرة شرعا. فالأعمال الصادرة من

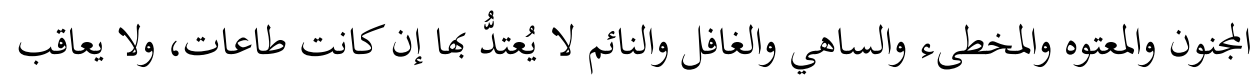
عليها إن كانت معاصي. r- - أن النية سر العبودية لله تعالى و روحها. قال ابن حزم -رحمه الله-: "النية هي سر العبودية وروحها، ومحلها من العمل محل الروح من الجسد، ومحال أن يعتبر في العبودية عمل لا روح

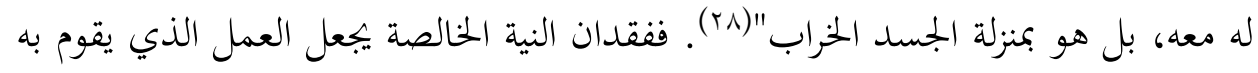

$$
\text { البدن ضربًا من العبث والضلال. }
$$

ع - النية لما تأثيرها الأساسي في العمل. فيصير تارة حراما، وتارة حلالا، وصورته واحدة، كالذبح

مثلا، فإنه يحل الحيوان إذا ذبح لأجل الله، ويحرمه إذا ذبح لغير الله، والصورة واحدة.

هذه المكانة والمنزلة الرفيعة للنية والقصد في الشريعة الإسلامية جعلت من الضرورة وجود القواعد

الضابطة لها لتصل بالمسلم إلى ما كتبه الله له من الفلاح في الدنيا والقبول والثواب في الآخرة .

قواعد النيات و المقاصد عند الحافظ العراقي و ابنه أبي زرعة في كتاب "طرح التثيب": القاعدة الأولى: لا عمل إلا بنية / الأعمال بالنيات و المقاصد(؟) :

هذه القاعدة هي أولى القواعد الخمس الكبرى التي تتفرع و تتخرج عنها عدد لا ينحصر من القضايا

الكلية و الجزئيات. فالقاعدة تشمل عبادات و معاملات الفرد المسلم، إذ عليها ينبني الثواب و الأجور و العقاب و الجزاء، بل إليها تستند شروط صحة كثير من الأمور(·+). و هي نفس القاعدة الكبرى التى عبّر

$$
\begin{aligned}
& \text {. ابن حزم، إحكام الأحكام، (rı) }
\end{aligned}
$$

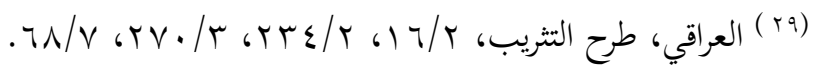

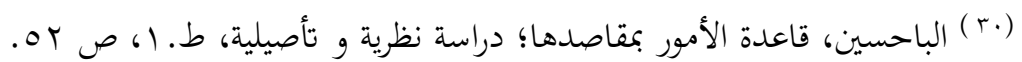


البصيرة: مجلة الدر اسات الإسلامية

AL-BASHIRAH: JOURNAL OF ISLAMIC STUDIES

Vol. 2 No. 1 (2021): 1-48

Website: https://journal.stiba.ac.id

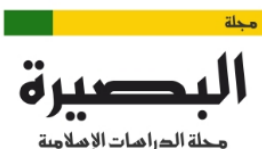

مجلة الصراهات الإهلامية

AL-BASHIRAH

عنها جمهور العلماء بقولم: "الأمور بمقاصدها"، و عليها يدور معناه و محتواه و إن اختلفت الالفاظ و

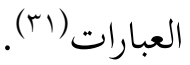

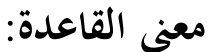

أما (الأعمال) فهي جمع "عمل"، و هو في اللغة عام يشمل كل فعل يفعل به(rr).

و من مبررات اختيار لفظ "الأعمال" دون "الأمور" -و إن كان جمهور الفقهاء على صيغة "الأمور

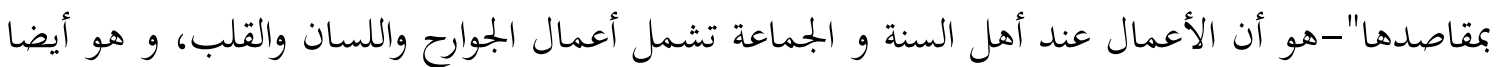
مطابق للصيغة النبوية: (الأعمال بالنيات)(rr).

أما (النيات) فهي جمع "نية"، هي تدل على معنيين: (1) "مقصد لشيء"، و و (r) "عجم الشيئ"، أي: اتصف بالصلابة و الشدة(ז).

أما من حيث الاصطلاح، فهناك عدة تعاريف ، و لعل أرجحها ما ذكره الغزالي من أها: "هي

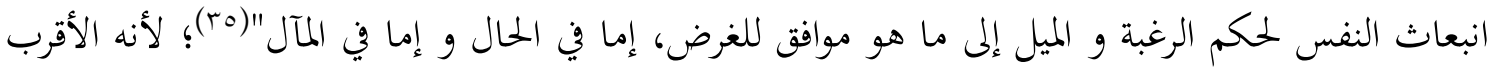

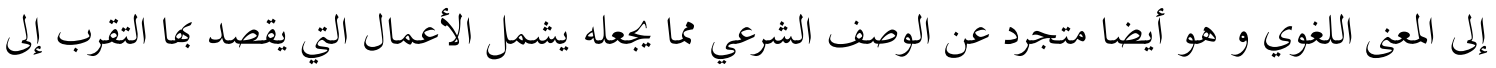
الله تعالى و مما هي ليست كذلك.

أما (المقاصد) فهي جمع "مقصد"، و أصله من "القصد"، و من معاني هذه الكلمة: (1) إتيان

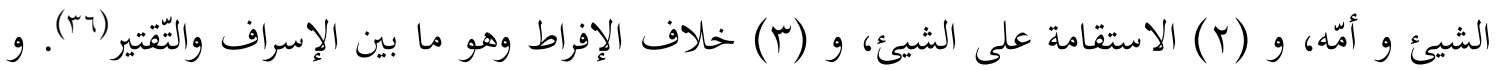

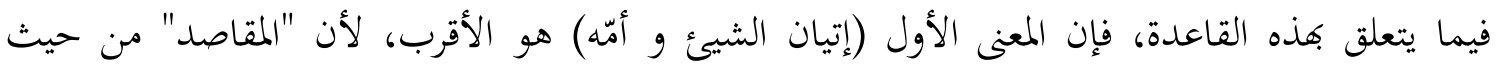

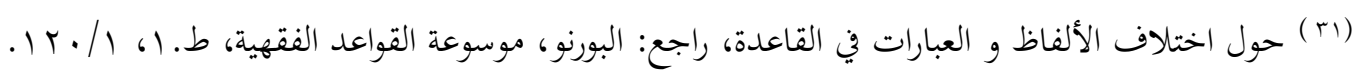

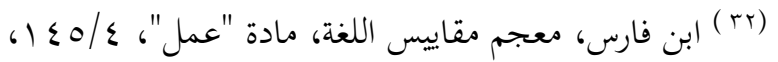

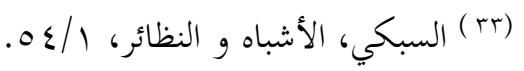

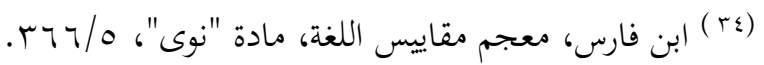

$$
\begin{aligned}
& \text { (ro) }
\end{aligned}
$$

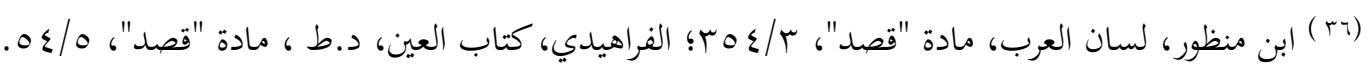


البصيرة: مجلة الدر اسات الإسلامية

AL-BASHIRAH: JOURNAL OF ISLAMIC STUDIES

Vol. 2 No. 1 (2021): 1-48

Website: https://journal.stiba.ac.id

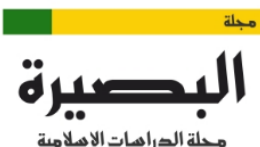

مجلة الصراهات الإهلامية

AL-BASHIRAH

الاصطلاح هي "الإرادة المتوجهة إلى الأمور"(rV)، أو هي "الدوافع و الدواعي التي بتعل المكلف يتجه بما

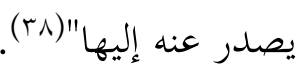

هذا، و ينغي أن ينبه بأن الفقهاء مع ذكرهم القاعدة بصيغة "الأمور بمقاصدها"، و لكنهم في مجال

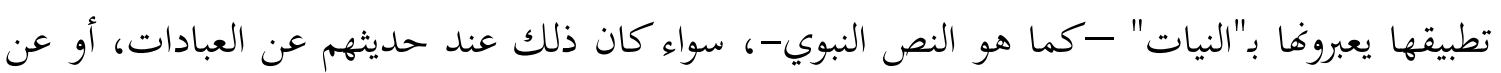

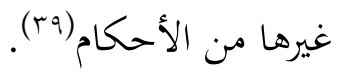

أما المعنى الإجمالي للقاعدة، هو: أن كل شيئ يصدر عن المكلفين من تصرفات فإن أحكامها بحسب

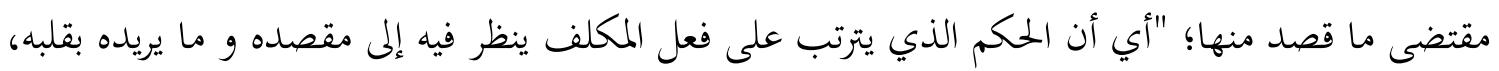

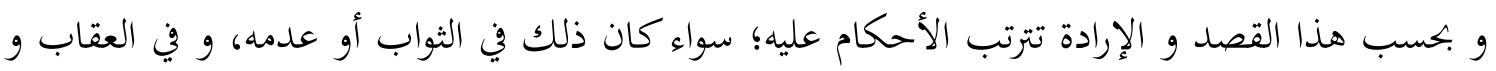

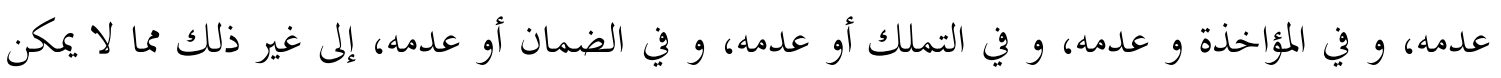

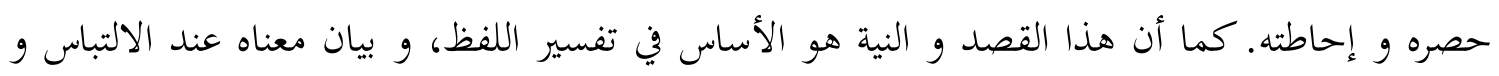
الغموض، و في ترتيب الآثار عليه"(.ء).

هذا المعنى يدلنا على عظم مكانة النية و علو منزلتها و قدرها في حياة المسلم، إذ جميع تصرفاته من الأعمال و الأقوال و ما أبرم من العقود و الاتفقات مبنية على نياته و مقاصده التي بعثثه إلى تلك الأعمال.

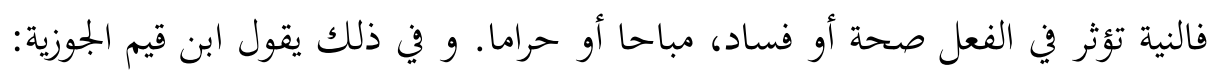

"فأما النية، فهي رأس الأمر و عموده، و أساسه و أصله الذي عليه يبنى، فإنها روح العمل و قائده

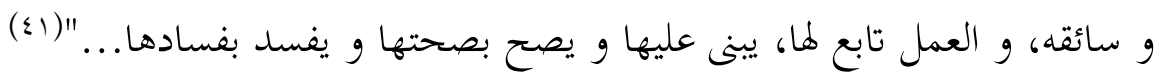

$$
\begin{aligned}
& \text { (rv) الباحسين، المفصل في القواعد، ص rrv) } \\
& \text { r^) }
\end{aligned}
$$

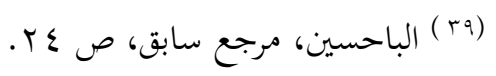

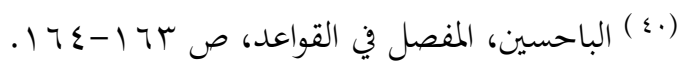

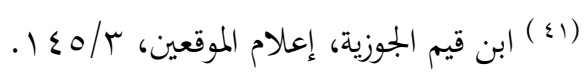


البصيرة: مجلة الدر اسات الإسلامية

AL-BASHIRAH: JOURNAL OF ISLAMIC STUDIES

Vol. 2 No. 1 (2021): 1-48

Website: https://journal.stiba.ac.id

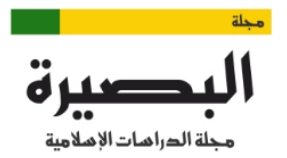

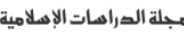

AL-BASHIRAH

فالأعمال كلها تابعة و منقادة للنيات. و صلاح الأعمال مرتبطة بصلاح النيات، كما أن فساد النيات تستلزم فساد الأعمال.

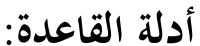

الأدلة الدالة على هذه القاعدة الجليلة كثيرة و متنوعة، و لعلنا نذكر أهم تلك الأدلة للقاعدة بشيع

$$
\text { من الإيجاز: }
$$

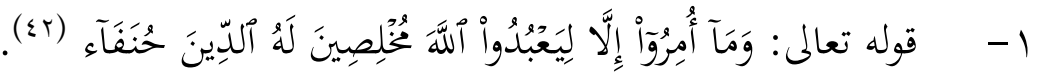

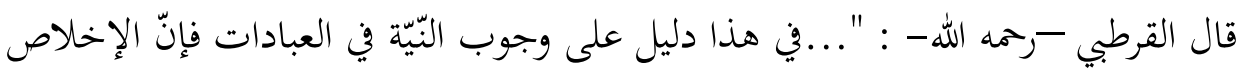

$$
\begin{aligned}
& \text { من عمل القلب وهو الّذي يراد به وجه الله تعالى لا غيره"(r؟). }
\end{aligned}
$$

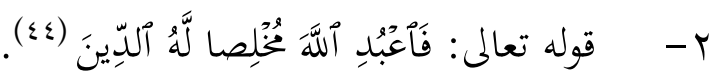

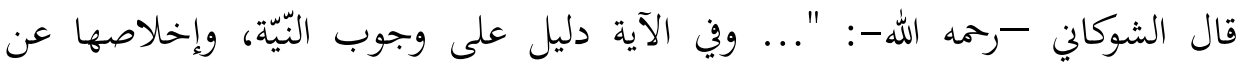

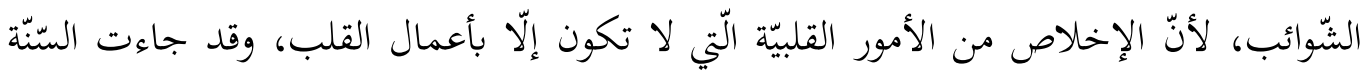

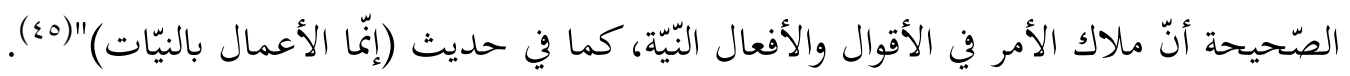

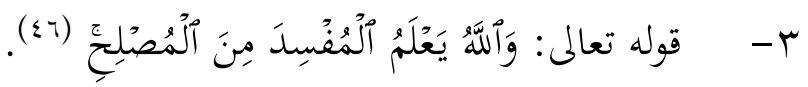

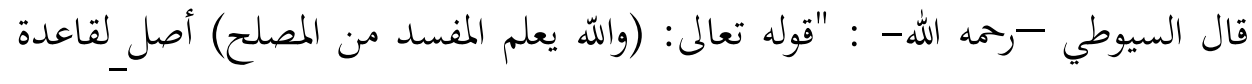

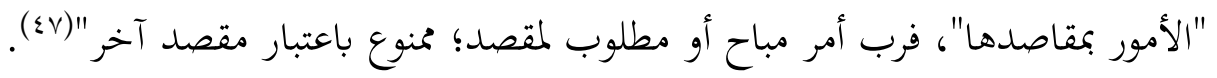

$$
\begin{aligned}
& \text { (r) سورة البينة: جزء من الأية ه. }
\end{aligned}
$$

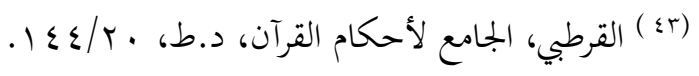

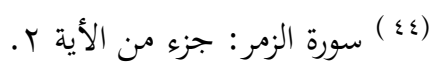

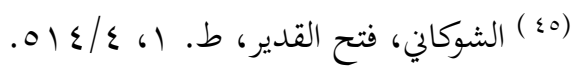

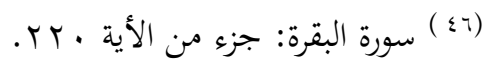

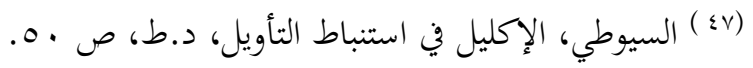


هذه الأيات و ما أشبهها تدل على وجوب النية و اعتبارها في جميع الأعمال، و على اعتدادها في جميع التصرفات، و أن الإنسان سيؤاخذ بناء على ما يقصده و ينويه في قلبه.

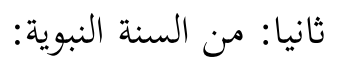

1- حديث عمر بن الخطاب -رضي الله عنه-، قال: سمعت رسول الله صلّى الله عليه

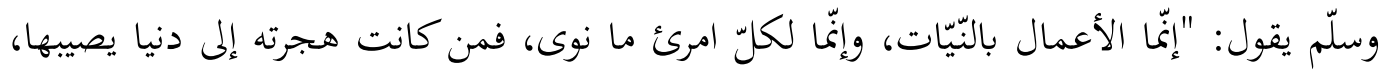

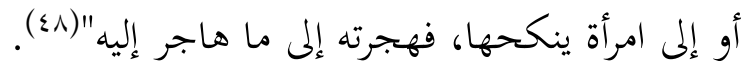

و قد تقدم معنا أن هذا الحديث هو الأصل الأصيل التي تنبني هذه القاعدة عليها، بل يعتبر هذا الححديث أقوى أدلة هذه القاعدة. و قد صرّح كثير من العلماء الكبار على أهمية هذا الحديث.

$$
\text { قال الحافظ العراقي -رحمه الله-: }
$$

"هذا الحديث قاعدة من قواعد الإسلام حتّى قيل فيه: إنّه ثلث العلم وقيل ربعه وقيل خمسه

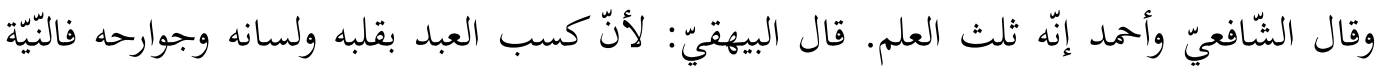

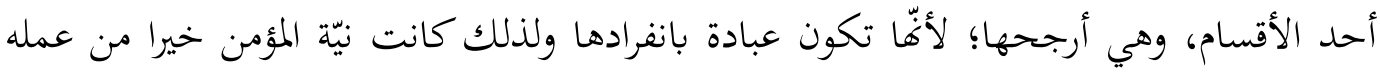

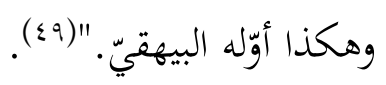

فهذا الحمديث -وغيره من الأحاديث- يدل دلالة واضحة على أن النية هي ميزان الأعمال. فالنية هي التي ترفع الأعمال و تخفضها، و بحسبها يتعين ما يحصله الإنسان من عمله.

$$
\text { ثالثا: الإجماع: }
$$

لقد انعقد إجماع المسلمين في عصور متعاقبة منذ عصر الصحابة فما بعده على هذه القاعدة تابعا

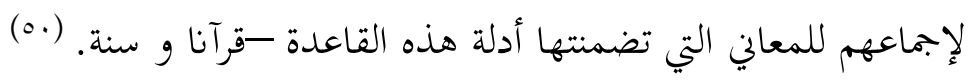

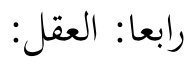

أما من حيث العقل، فكما يقول شيخ الإسلام ابن تيمية -رحمه الله-:

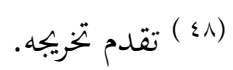

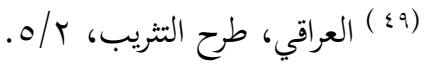

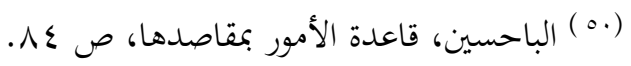


"لو كلف العباد أن يعملوا عملا بغير نية، كلفوا ما لا يطيقون؛ فإن كل أحد إذا أراد أن يعمل عملا

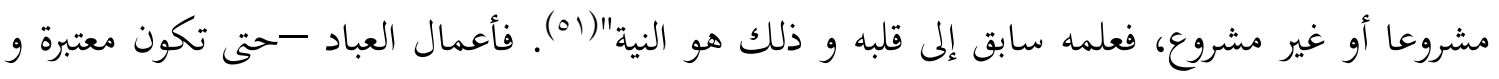

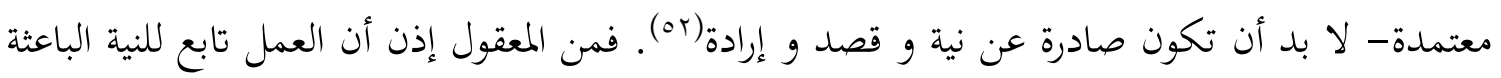

1- الأخذ بالدنيا و نعيمها و الاستمتاع بها ليس مذموما على الإطلاق، و إنما بحسب

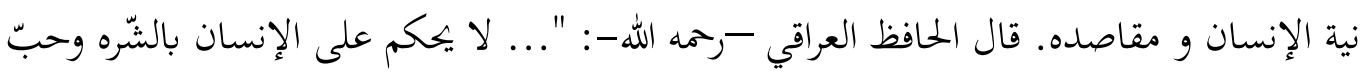

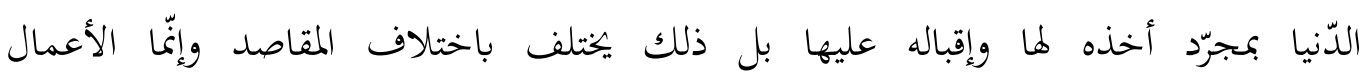

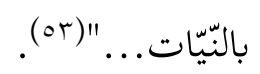
r- - المباحات إذا قصد بها التقوّي على العبادة أو التوصّل إليها كالأكل والنوم واكتساب المال وغير ذلك(ه)، فإنها تتحول إلى الطاعات و القربات، و يستحق فاعلها و العامل بها الثواب الجزيل و الأجر الوفير من اللهّ عزّ و جلّ.

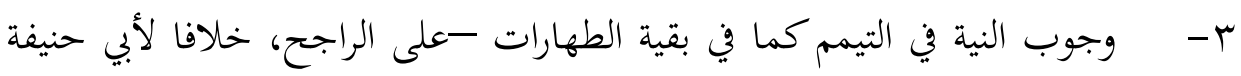

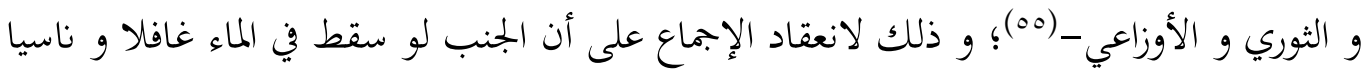

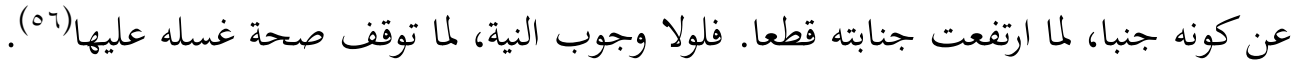

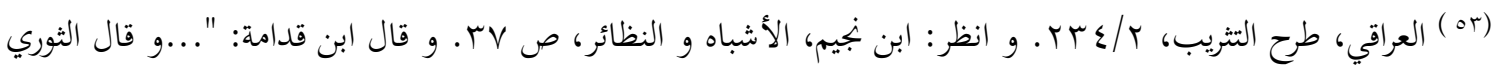

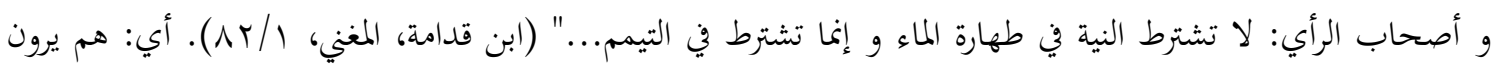
اشتراط النية في التيمم فقط دون غيره من الطهارات.

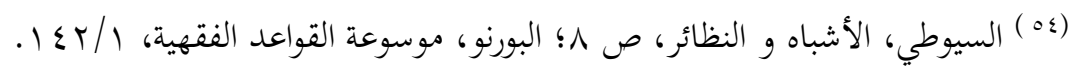

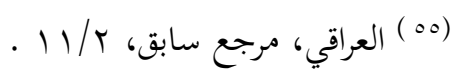

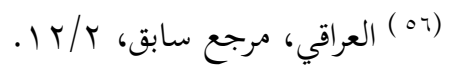


البصيرة: مجلة الار اسات الإسلامية

AL-BASHIRAH: JOURNAL OF ISLAMIC STUDIES

Vol. 2 No. 1 (2021): 1-48

Website: https://journal.stiba.ac.id

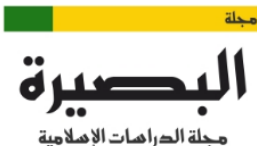

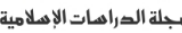

AL-BASHIRAH

ع - عقود المعاوضات والتمليكات المالية - كالبيع والشراء والإجارة والصلح والهبة-

عند إطلاقها ولم يقترن بها ما يقصد به إخراجها عن معناها الذي وضعت عليه؛ فإنها تفيد حكمها،

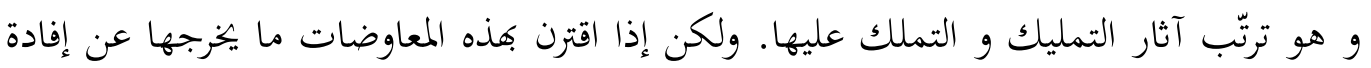

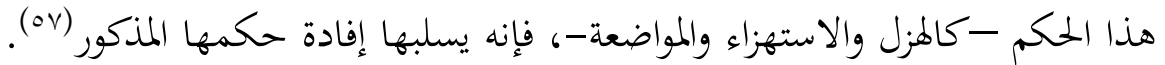

القاعدة الثانية: الإخلاص معتبر في الأعمال (ه^)

و لماكان المقصود من العبادات و الطاعات و القربات هو وجه الله تعالى و طلب مرضاته و الحصول

على ثوابه، كان لا بد من هذا الشرط المهم لقبول العبادات والقربات وترتّب ثواجها؛ وهذا الشرط هو

الإخلاص(90). فمن هنا جاءت أهمية هذه القاعدة وأهمية إفرادها كقاعدة مستقلة للدلالة على ضرورية إخلاص النية في الأعمال(.).

ويؤكده قول القرافي-رحمه الله-: "فالثواب في الحقيقة مرتّب على مراتب الإخلاص لا على مراتب

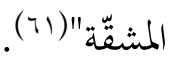

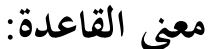

(الإخلاص) في اللغة: الصفاء وزوال الشوب من الشيء والسلامة والنجا(T). وحقيقة الإخلاص في

الطاعة هو أن يريد العبد بعمله التقرب إلى اللّ تعلى وحده، أو إرادة وجه الله تعالى من العبادة والأعمال (rآ).

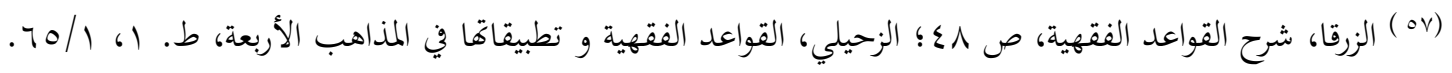

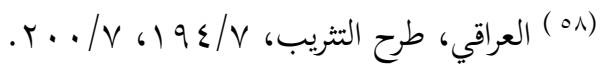

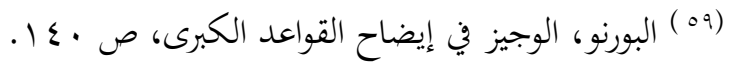

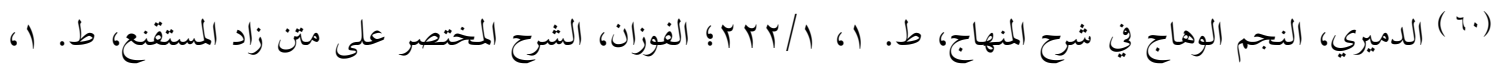

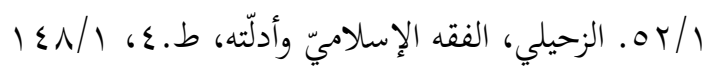

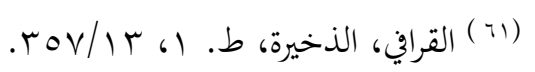

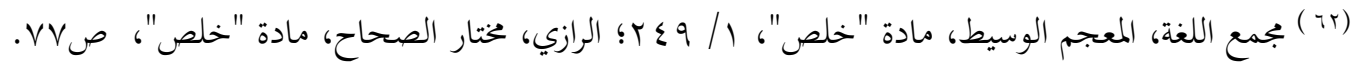

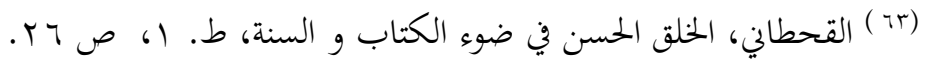


أما قوله (معتبر) فهو مفعول من "الاعتبار" وهو يدلّ على النّفوذ والمضيّ في الشّيء (ـ؟) ـ وهذا المعنى هو

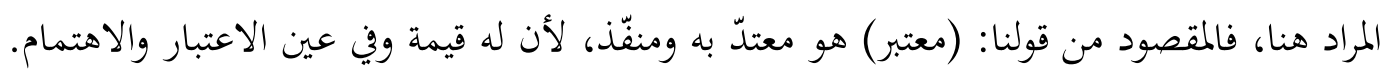

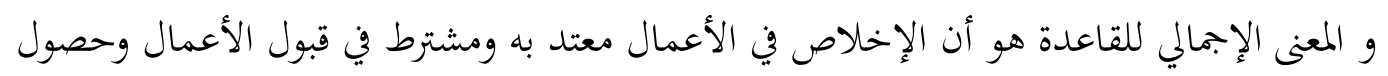

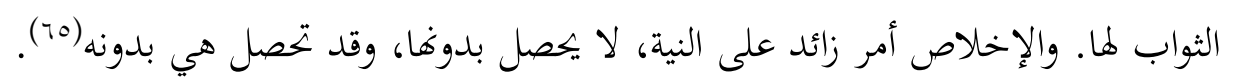

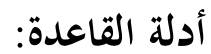

كل ما سبق ذكره في القاعدة السابقة من الأدلة هو نفس الأدلة التي نستدل بها لهذه القاعدة.

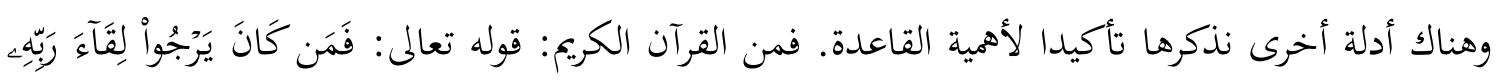

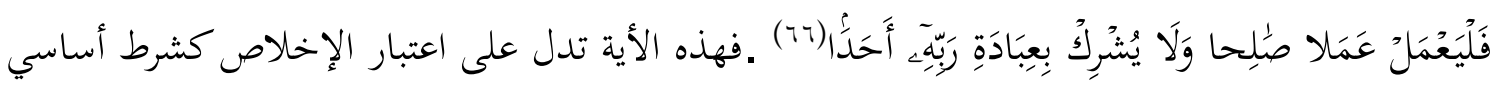

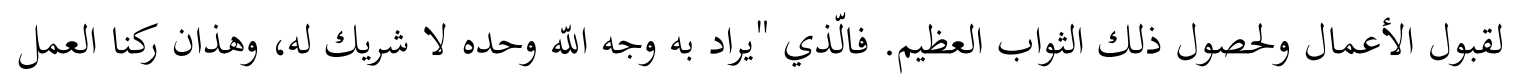

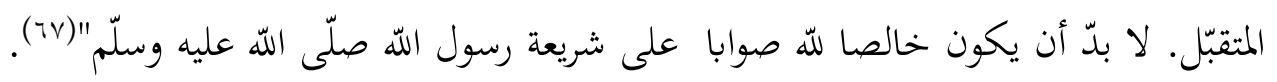

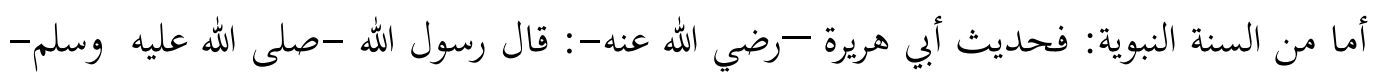

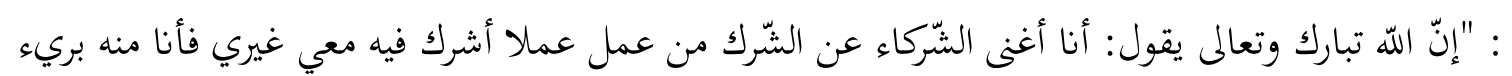

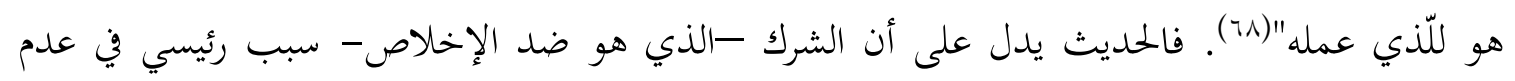

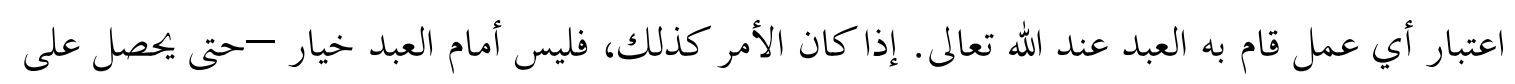

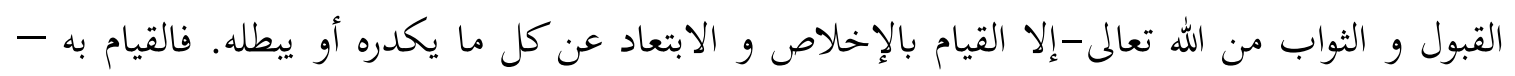

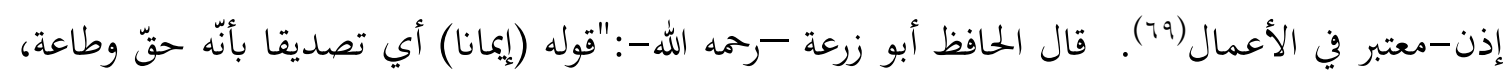

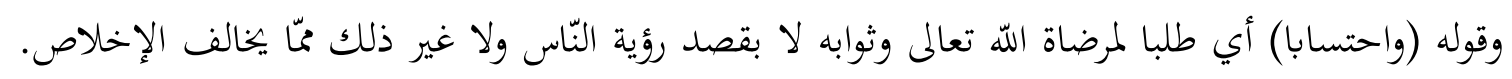

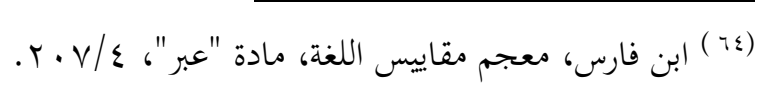

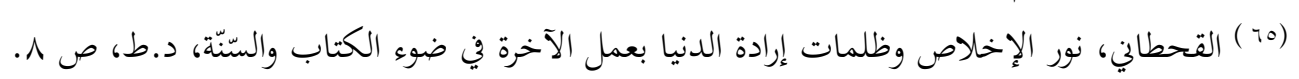

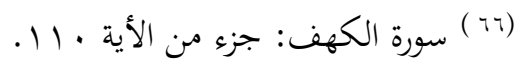

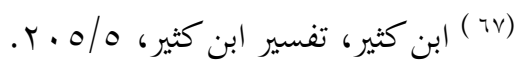

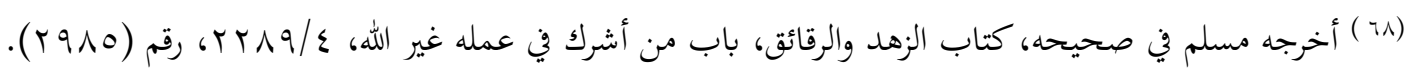

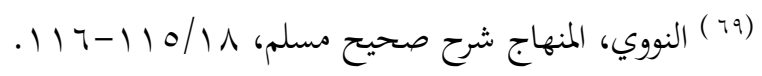


البصيرة: مجلة الدر اسات الإسلامية

AL-BASHIRAH: JOURNAL OF ISLAMIC STUDIES

Vol. 2 No. 1 (2021): 1-48

Website: https://journal.stiba.ac.id

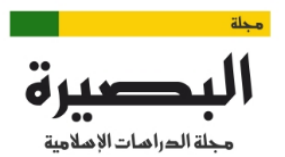

AL-BASHIRAH

والاحتساب من الحسب وهو العدّ كالاعتداد من العدّ، وإنّما قيل لمن ينوي بعمله وجه الله احتسبه؛ لأنّ له

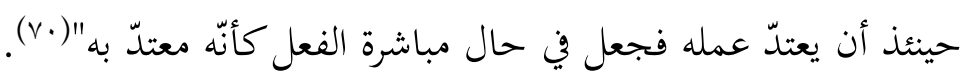

هنا يشير الحمظظ العراقي إلى أن "الاحتساب" هو بمعنى الاعتداد والاعتبار، فالحديث يدل على أن

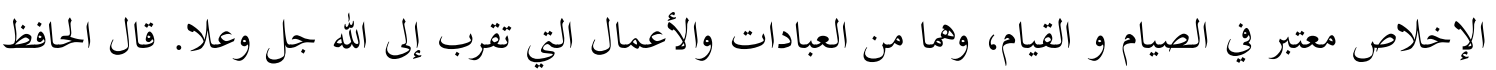

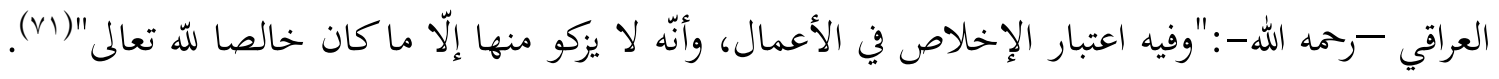

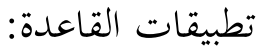

1- - الصلاة والصوم والزكاة والحج من الأعمال التي تشترط في صحتها وفي حصول ثوابها النية.

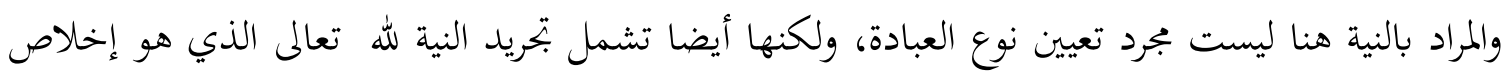
الدين والطاعات له وحده تعالى، ف"الإخلاص محض النية"(Vr).

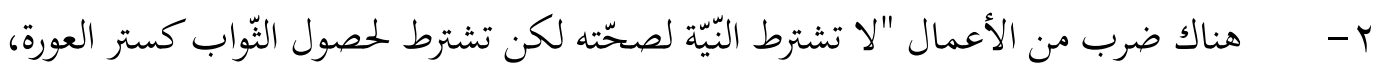

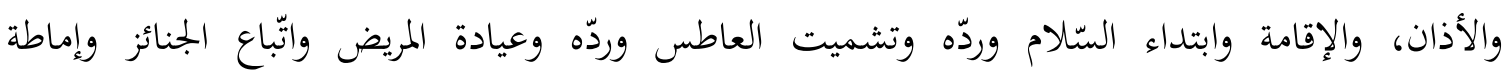

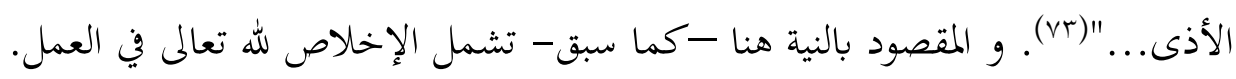

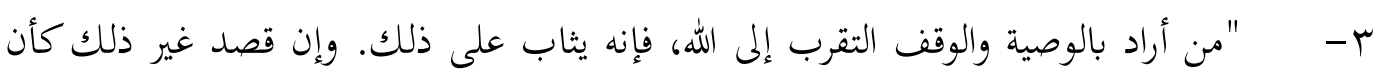

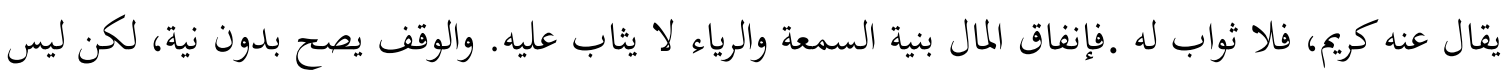

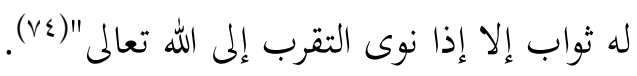

القاعدة الثالثة: التشريك في النية لا يلزم منه فسادها(V•):

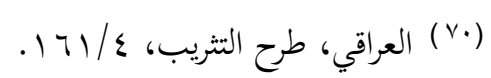

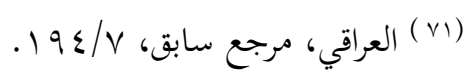

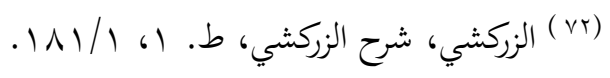

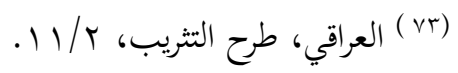

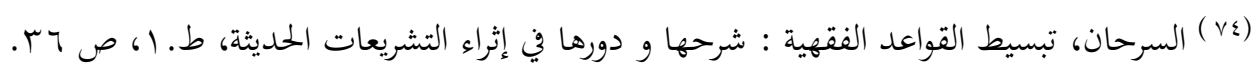

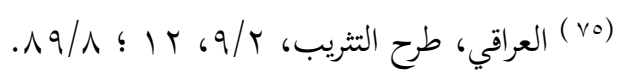


هذه القاعدة من أهم القواعد المتفرعة عن قواعد النيات و المقاصد. وهي قاعدة شريفة جليلة لمن

حذقها وفهمها وأحسن تطبيقها في حياته ومسيرته إلى الله تبارك وتعالى (VT).

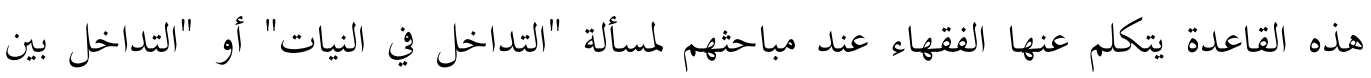

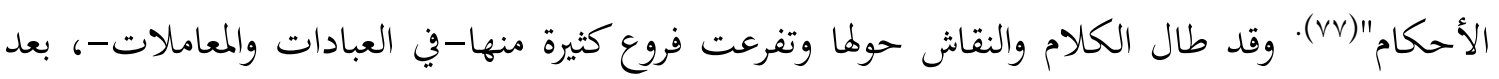

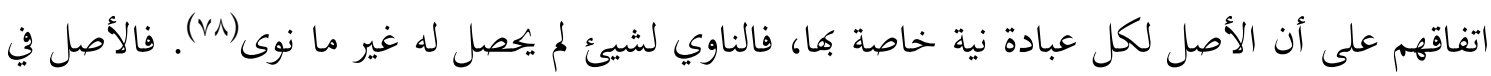

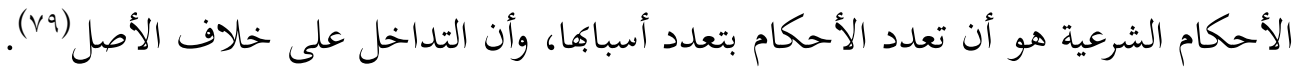

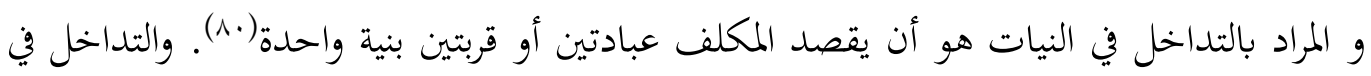
النيات جائز عند الفقهاء في حالات خاصة بالاستثناء، وهذه الحالات المستثناة قد تحقق فيها مناط التداخل

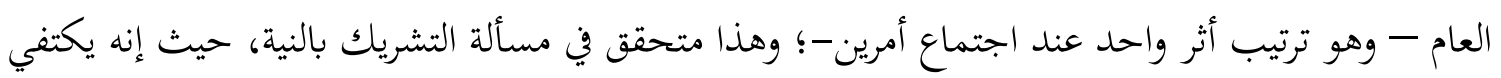

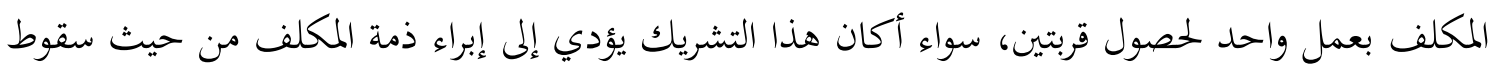

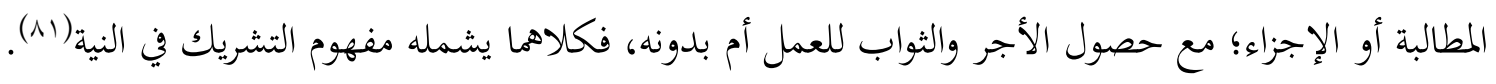

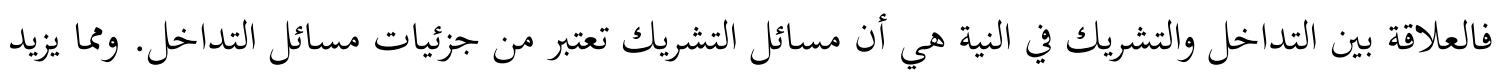

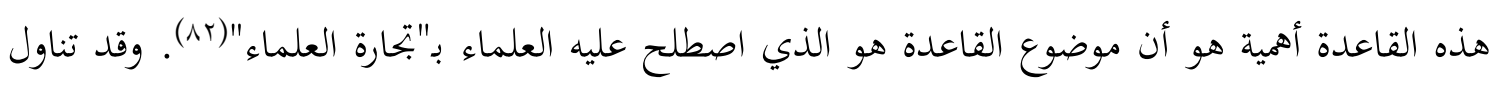

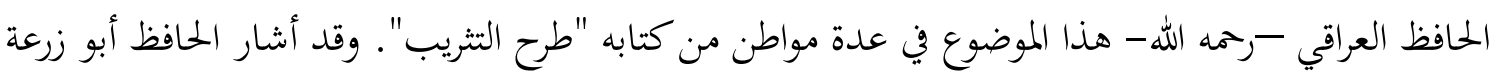

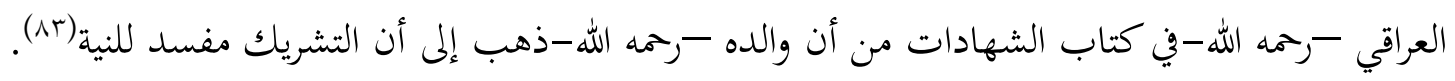

$$
\begin{aligned}
& \text { (rr) ابن قيم الجوزية، الداء و الدواء (الجواب الكافي لمن سأل عن الدواء الشافي)، ط. اه ص سד؟. }
\end{aligned}
$$

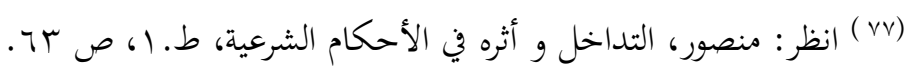

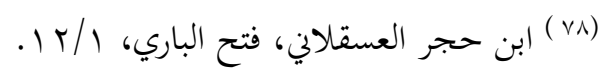

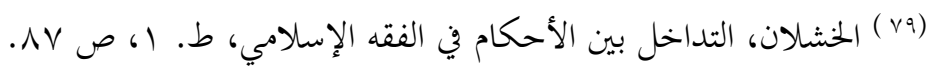

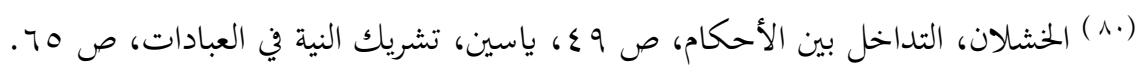

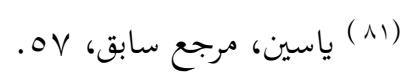

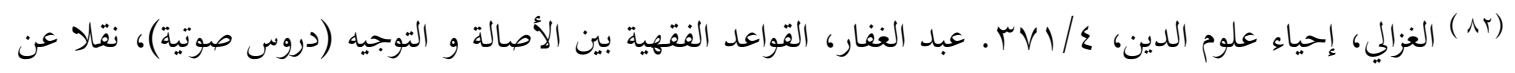

$$
\begin{aligned}
& \text { ياسين، تشريك النية في العبادات، ص مه هـ }
\end{aligned}
$$

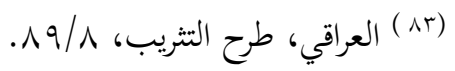


ولكن بالرجوع إلى كلام الحافظ أبي الفضل العراقي -رحمه الله- في حديث (إنما الأعمال بالنيات)،

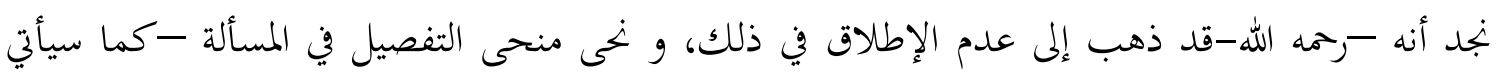

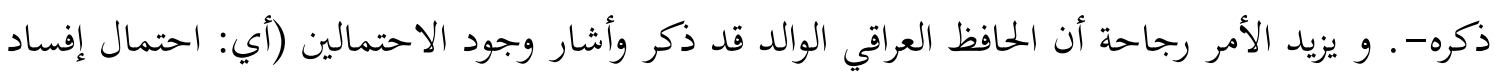

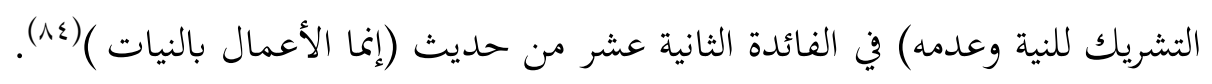

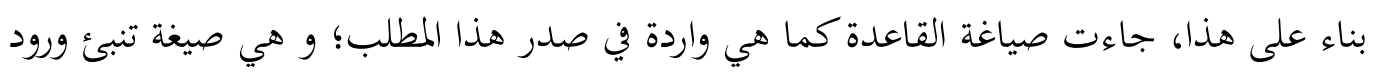

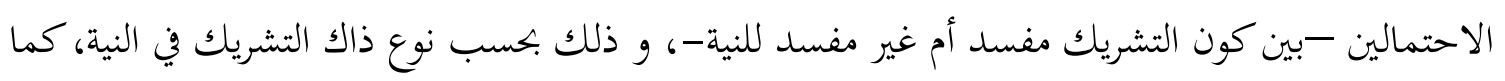
سيأتي.

\section{معنى القاعدة: - م}

قوله: (التشريك) في اللغة بمعنى المشاركة والمقارنة (ه). فالتشريك هو جعل الشيئ شريكا وقرينا لغيره في أمر من الأمور.

أما في الاصطلاح فمن تعاريف "التشريك" هي: "أن يقصد بالعمل الواحد فريضتين"(ـ). أو

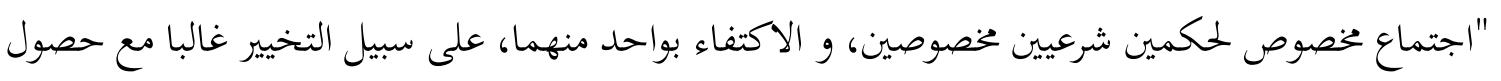
ثوابهما معا، أو ثواب واحد منهما"(Av). بناء على هذه التعاريف، يمكننا أن نلخص حالات التهات التشريك بالنية إلى ثلاثة حالات:

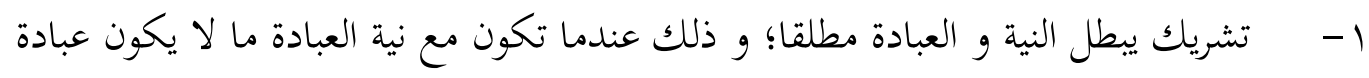

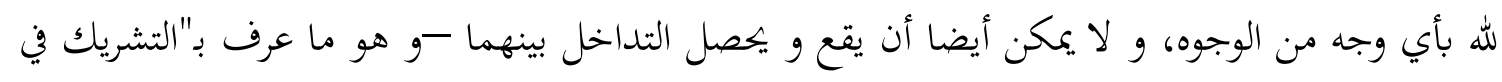

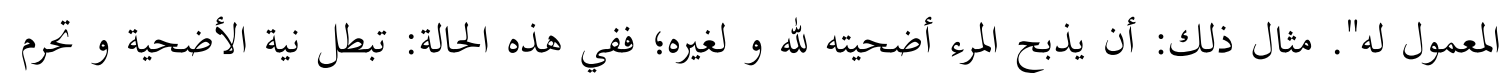
الذبيحة(1) (1).

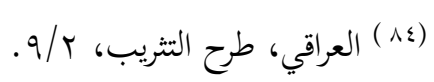

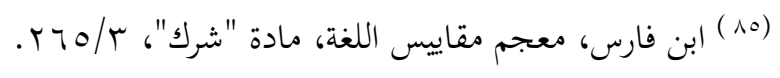

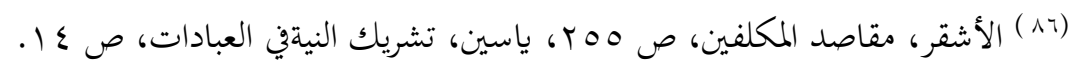

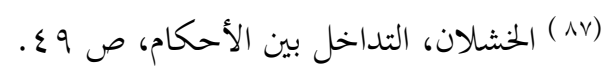

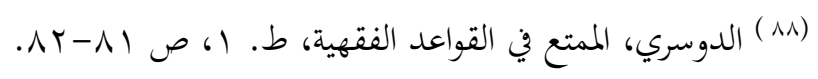




\section{r- تشريك لا يبطل النية و لا العبادة؛ و ذلك على صورتين:}

الصورة الأولى: أن يضم مع نية العبادة نية طلب حاجة أو منفعة دنيوية مباحة. مثال ذلك: أن وردين:

يغتسل المرء بالماء و ينوي به الغسل من الجنابة و التبرد. في هذه الصورة، اختلف الفقهاء في جوازه إلى

القول الأول: أن هذا النوع من التشريك في النية كالرياء، و ذلك لأن من قصد هذه المنفعة الدنيوية لم يعبد

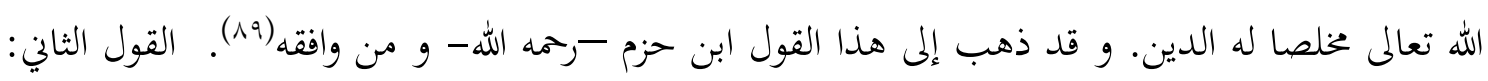

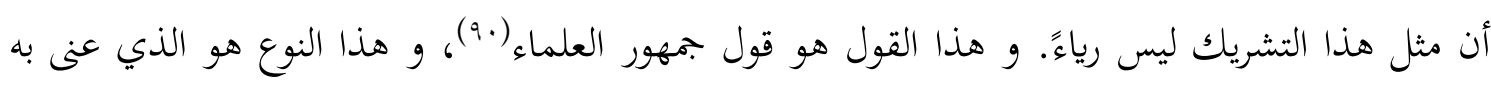

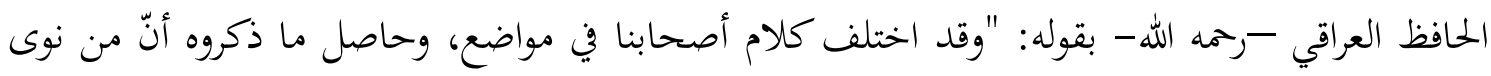

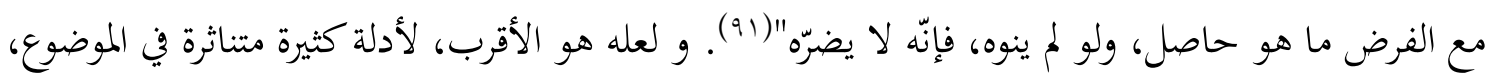

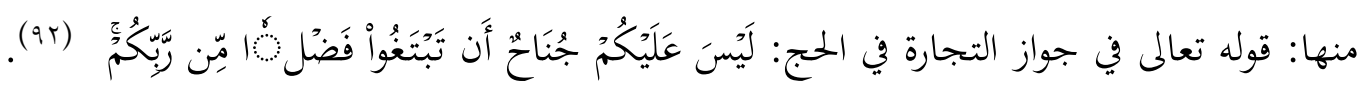

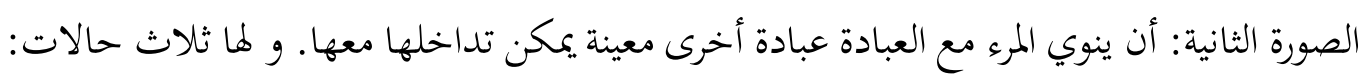

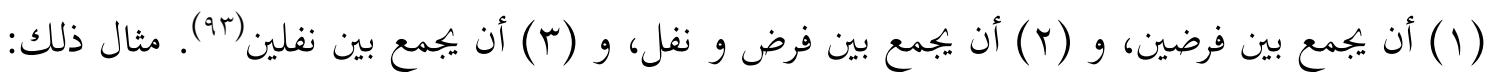

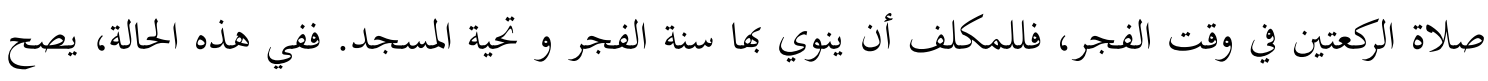

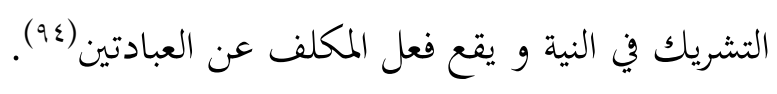

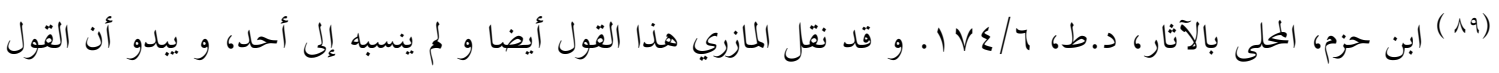

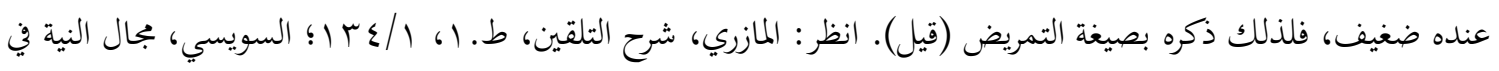

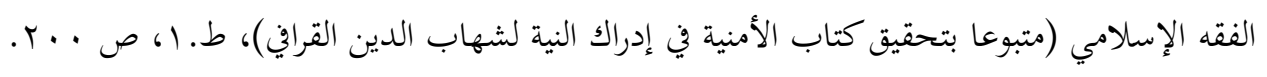

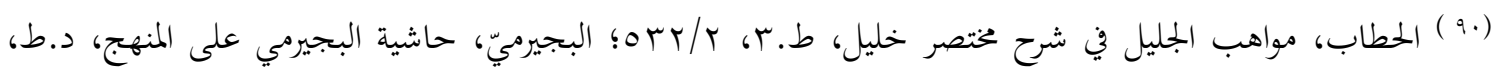

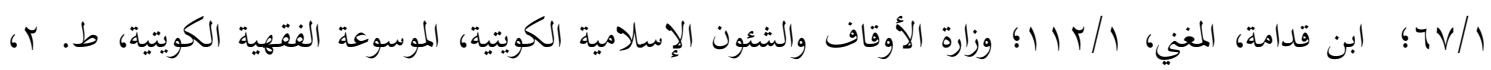

$$
\text { r } r \varepsilon-r r / T
$$

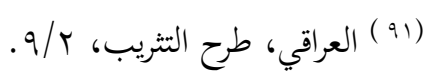

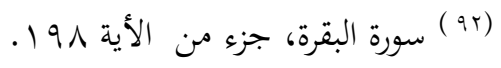

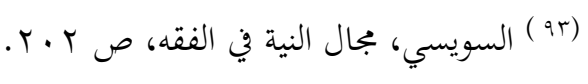

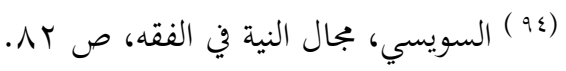


r- تشريك تبطل فيه نية إحدى العبادتين دون الأخرى؛ و ذلك عندما ينوي المرء مع العبادة

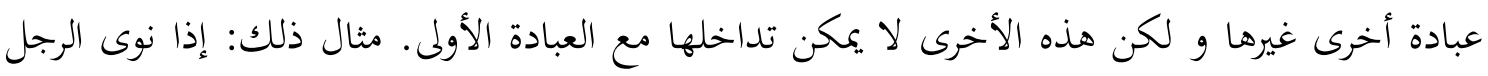

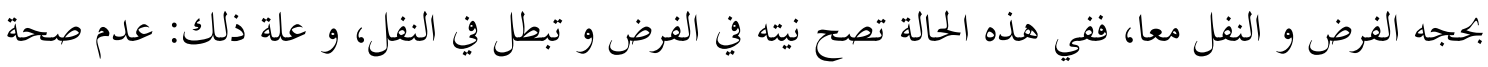

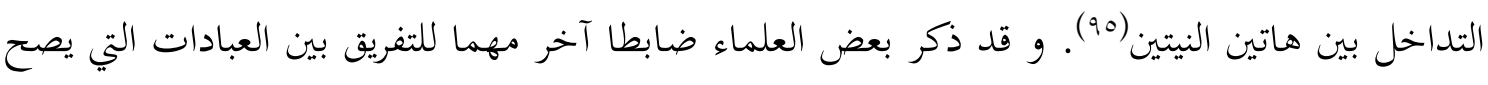

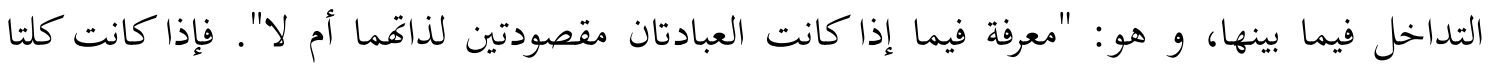

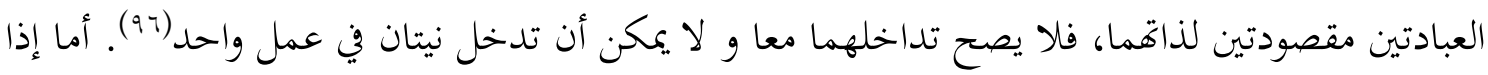

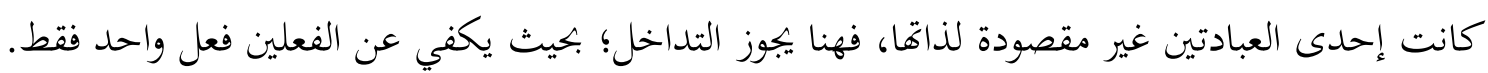

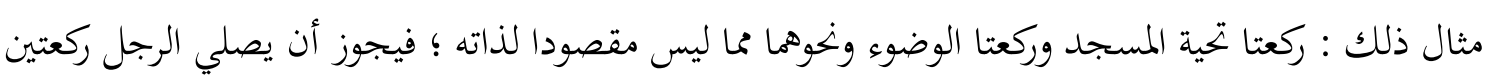

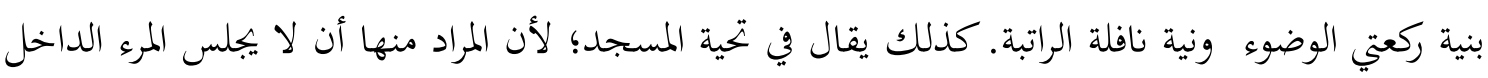

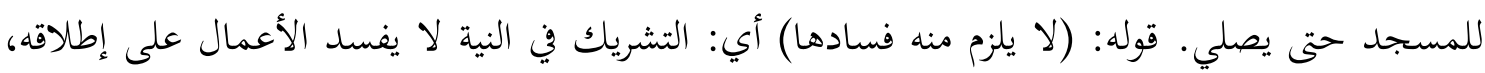

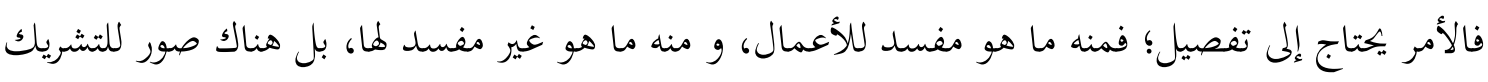

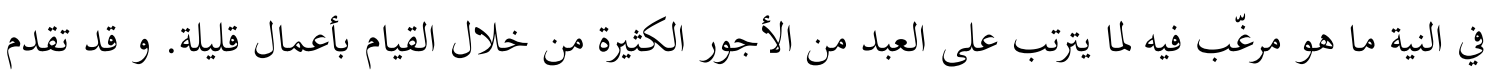

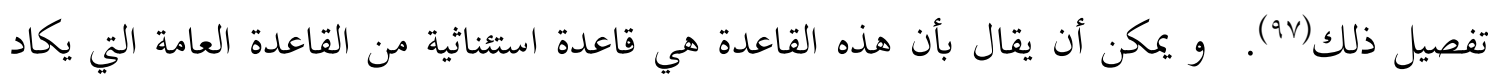

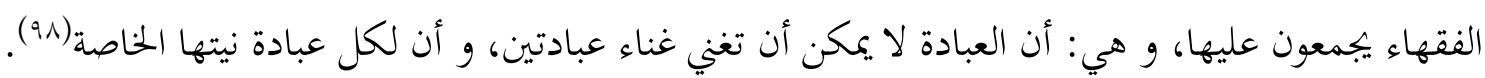

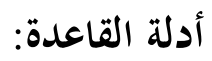

يبستدل لهذه هذه القاعدة بأدلة من الكتاب و السنة؛ منها ما هي دالة على بطلان الأعمال إذا

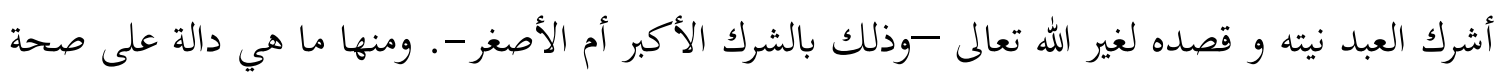

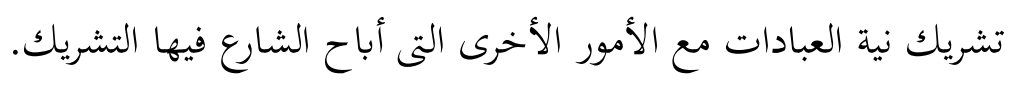

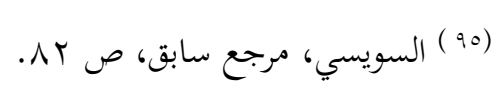

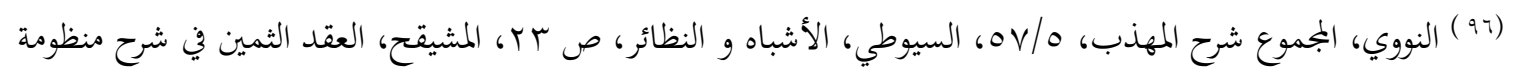

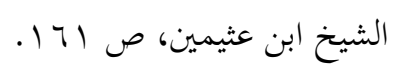

المان (9V)

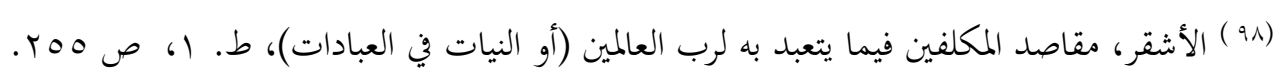




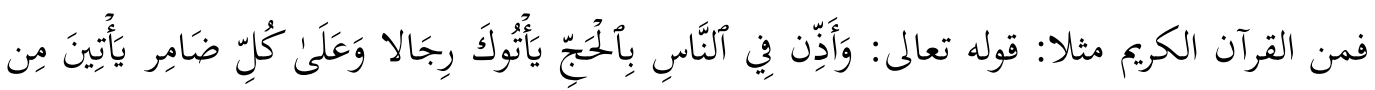

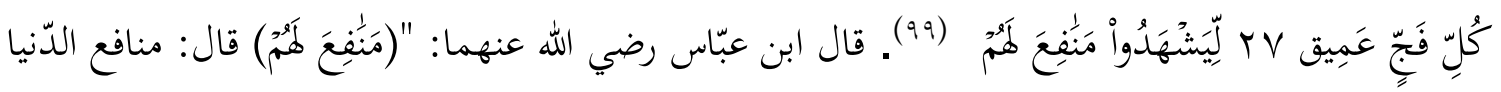

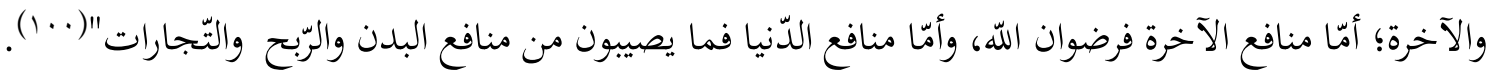

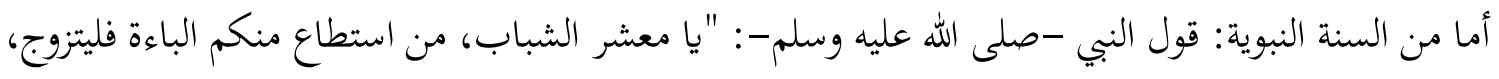

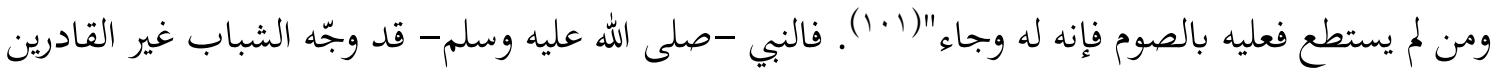

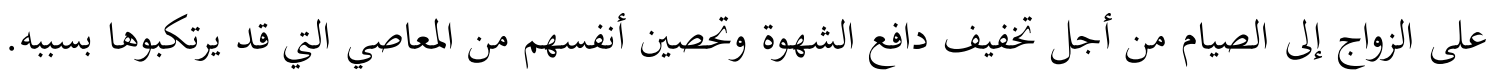

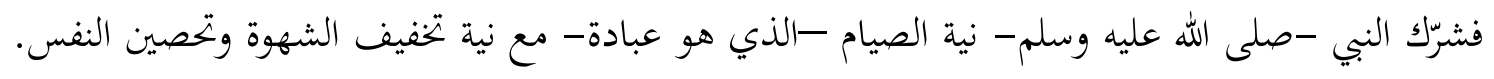

$$
\text { تطبيقات القاعدة: }
$$

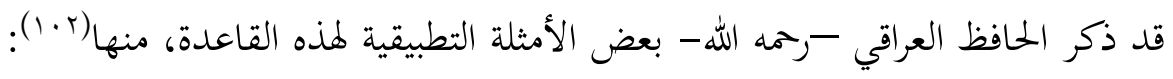

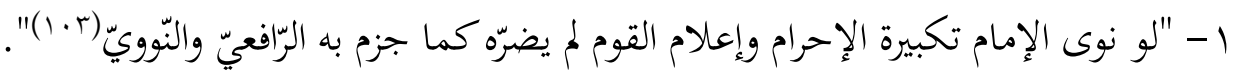

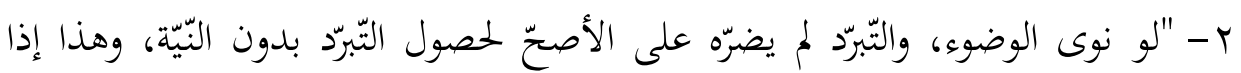

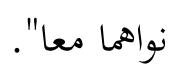

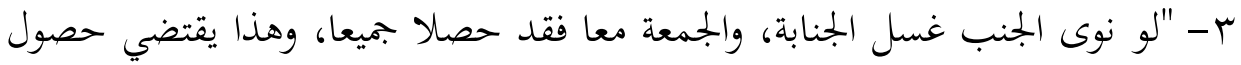

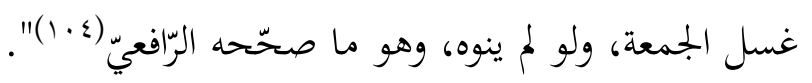

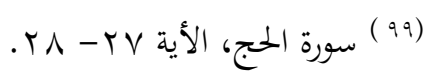

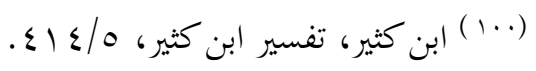

(1. 1 أخرجه البخاري في صحيحه، كتاب النكاح، باب قول النبي صلى الله عليه و سلم "من استطاع منكم الباءة أنساء

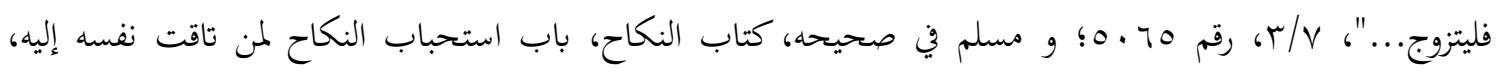

$$
\text { (19/r } 19 / \mathrm{r}
$$

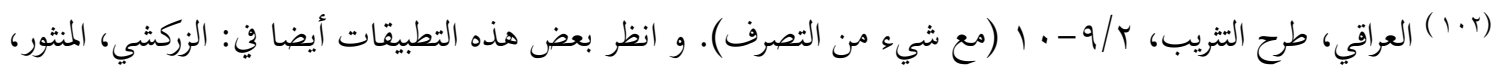

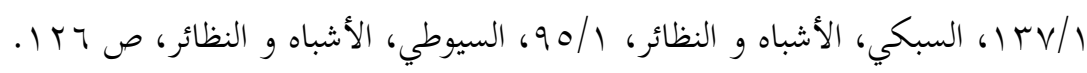

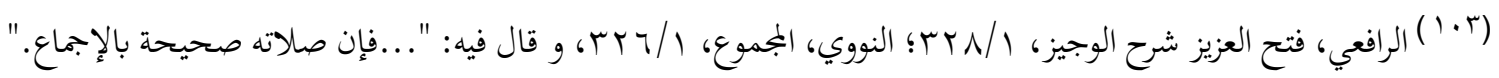

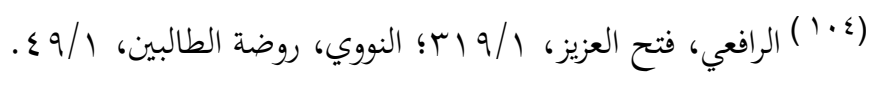


البصيرة: مجلة الدراسات الإسلامية

AL-BASHIRAH: JOURNAL OF ISLAMIC STUDIES

Vol. 2 No. 1 (2021): 1-48

Website: https://journal.stiba.ac.id

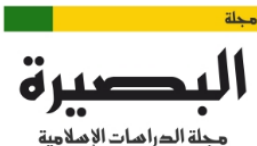

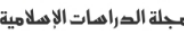

AL-BASHIRAH

ع - "إذا قصد المسبوق بتكبيرة الإحرام التّحرّم والهوى لا يصٌّ؛ لأنّ تكبيرة الإحرام لا

$$
\text { يكصل بها تكبيرة الهوى". }
$$

0ـ "لو نوى بخطبة الجمعة الجمعة، والكسوف لم يصحّ كما جزم به الرّافعيّ والنّويّ"(ه. (1).

القاعدة الرابعة: كما يشترط وجود النية أول العبادة يشترط استمرارها حكما إلى آخر

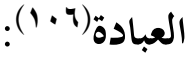

تختلف حالات النية بحسب طبيعة العمل التي ينبثق عنها. فهناك عمل يستدعي وقتا قصيرا للقيام به، و هناك عمل يتطلب وقتا أطول من ذلك لإنجازه. أما الأعمال التي تتطلب وقتا قصيرا في إنجازها، فأمرها واضح معروف، لأن المكلف الناوي للعمل ليس له إلا حالة واحدة؛ كمن نوى الاستثناء في اليمين و الكنايات في العقود.

أما الأعمال التي تتكون من أجزاء متعددة (كالطهارة والصلاة) أو التي تستغرق وقتا طويلا للقيام به (كالصيام والحج)، فهي التي تثير سؤالا عند العاملين لها: هل عليهم استصحاب النية ذكرا طول القيام بالعمل حتى هاية العمل أم يكفيهم استصحاب حكمها؟(ن. (1).

من هنا، تظهر أهمية هذه القاعدة لترشيد المكلفين العاملين إلى سبيل التيسير ورفع الحرج عنهم، بحيث إن القاعدة تدلمم و ترشدهم إلى الاكتفاء باستصحاب النية في العمل حكما، وأن ذلك يكفيهم ويرفع عنهم وجوب استصحابها ذكرا ، كما سيأتي. معنى القاعدة:

(كما يشترط وجود النية أول العبادة) أي: من المعلوم والمتفق عليه أن النية يشترط وجودها وجودا حقيقيا وحكميا عند الابتداء بالعمل. وهو أمر -في الحقيقة- لا يحتاج إلى شيء من التكلف من نفس

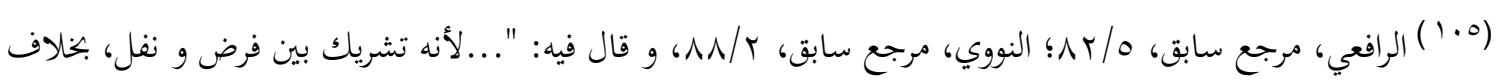
العيد و الكسوف، فإنه يقصدهما جميعا بالخطبتين، لأهما سنتان".

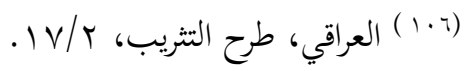

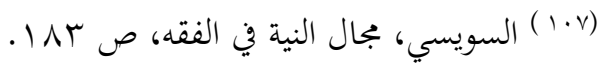


المكلف، فإن النية تتبع العلم. قال ابن تيمية ـرحه الله-: "... وذلك أنّ النّيّة تتبع العلم، فمتى علم العبد ما

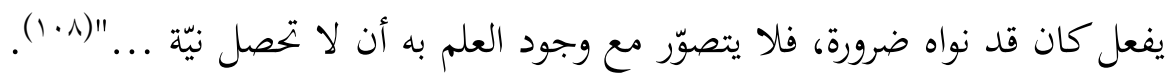

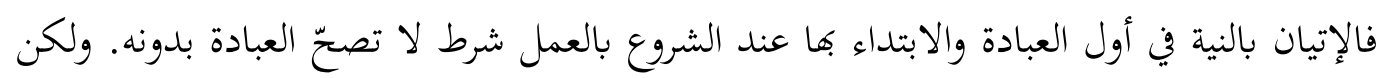

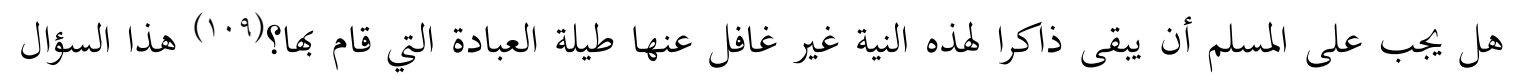

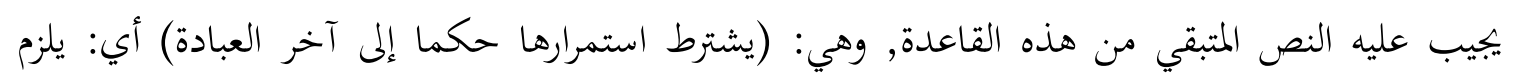

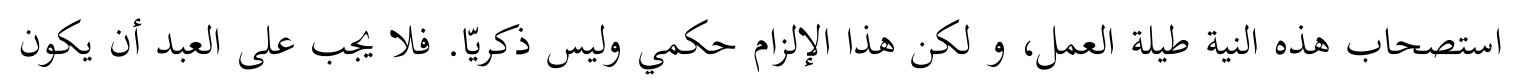

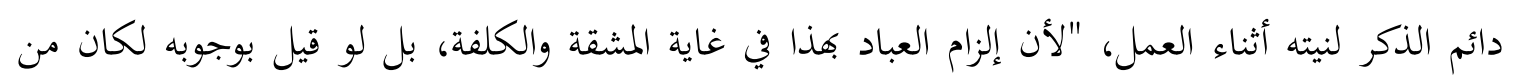

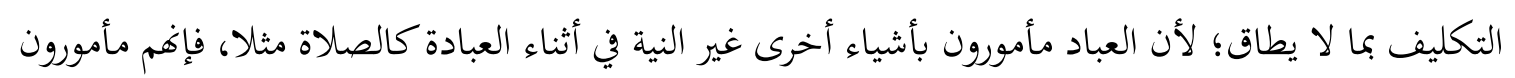

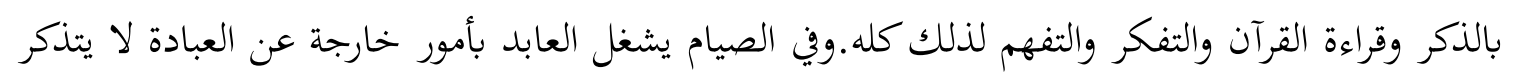

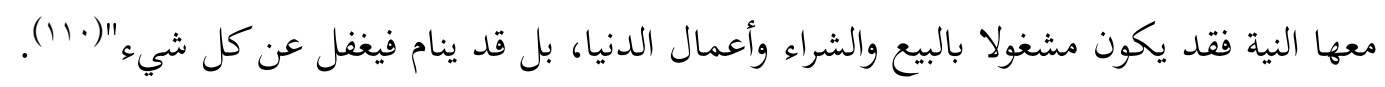
ومعنى "استصحاب حكم النية" أي عدم الإتيان بنية مضادة أو بما يقطعها في أثناء العبادة(11).

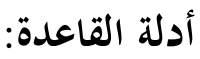

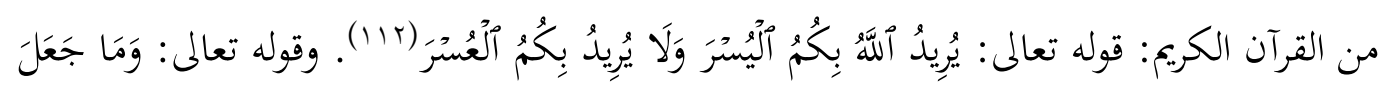

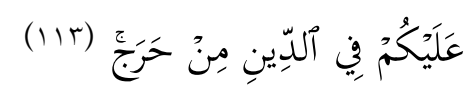

فمن المعروف شرعا هو أن النية التي تصاحب العمل هي الحكمية، لأنه يعسر ويشق على المكلف

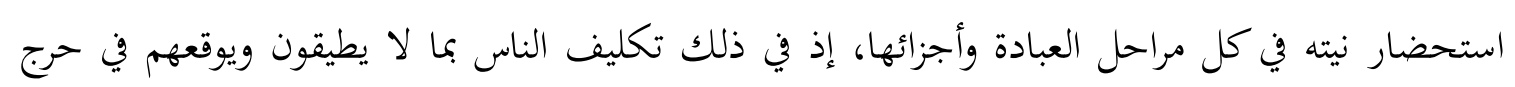

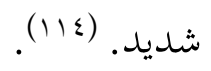

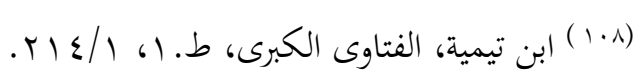

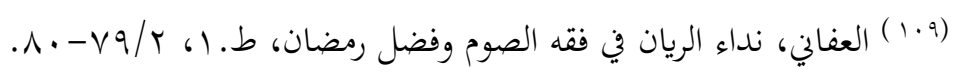

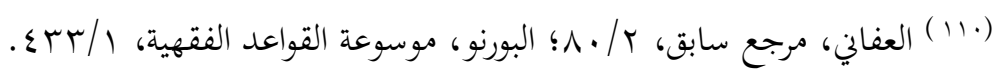

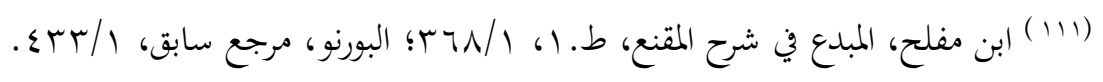

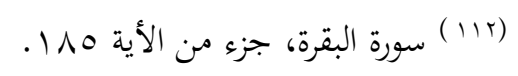

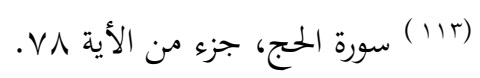

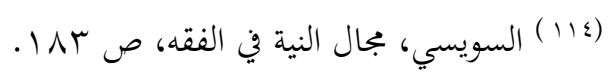


البصيرة: مجلة الدر اسات الإسلامية

AL-BASHIRAH: JOURNAL OF ISLAMIC STUDIES

Vol. 2 No. 1 (2021): 1-48

Website: https://journal.stiba.ac.id

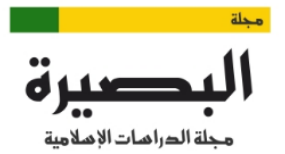

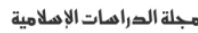

AL-BASHIRAH

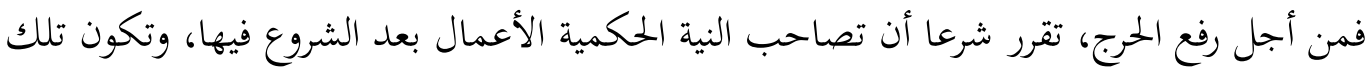

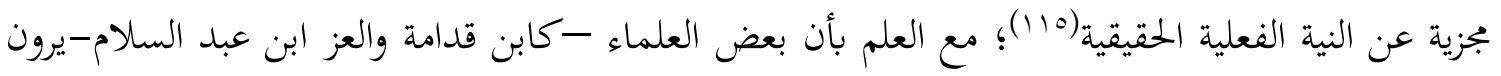

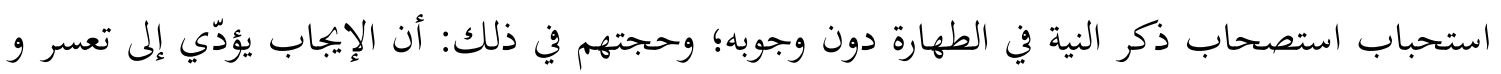
مشقة، و الله لا يكلف نفسا إلا وسعهاب(1/1). من الحديث النبوي: من أبرز الأدلة على هذه القاعدة هو حديث لهديث عمر -رضي الله عنه- السابق

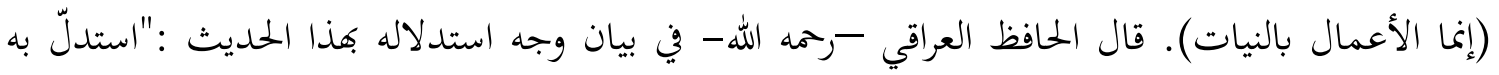

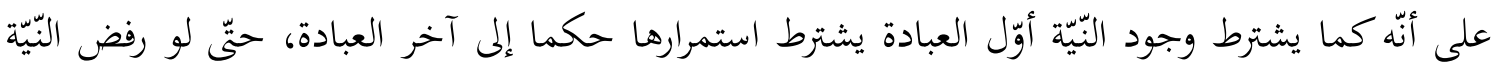

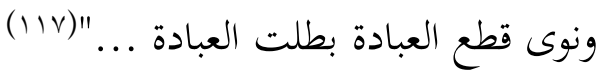

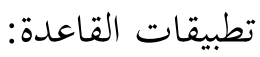

1 - ذكر نية الوضوء إلى غايته ليس بلازم؛ "لأنه وإن غفل عن النية حال وضوئه فإنه

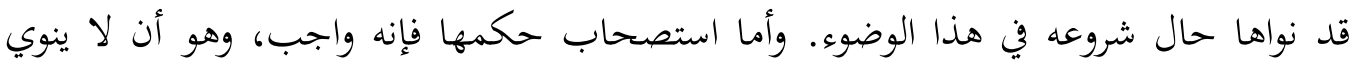

$$
\text { قطعها حتى تتم الطهارة" (111). }
$$

r- " "إذا نوى الصلاة عند تكبيرة الإحرام ثم عزبت عنه بعد ذلك فصلاته صحيحة ما لم يأت بنية مضادة أو فعل مفسد" (1/9). r- لو نوى الخروج من الصّوم فالأظهر أنهّ لا يبطل؛ لأنّه ترك وإمساك (r.1).

القاعدة الخامسة: تعاطي المباح على صورة استعمال الحرام يحرمها(Ir)

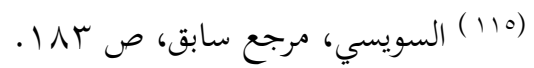

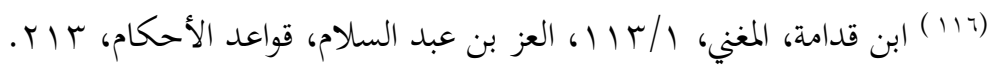

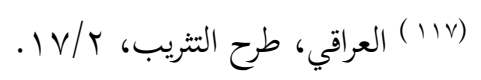

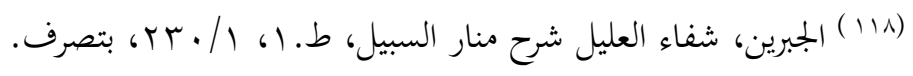

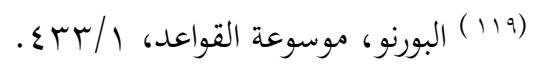

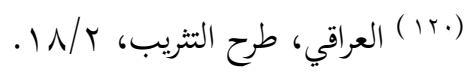

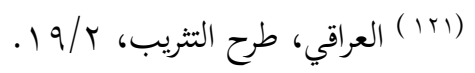


فهذه القاعدة تضبط تصرفات الإنسان عندما يباشر الأمور التي هي في الأصل من المباحات. ففي

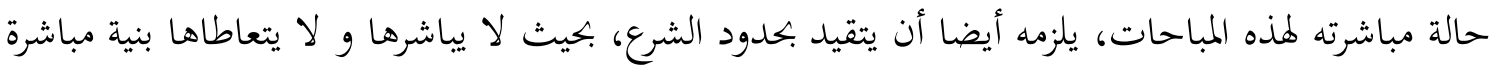

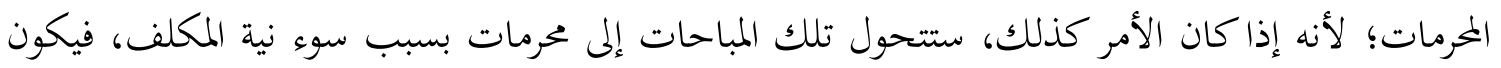

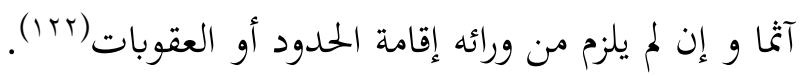

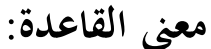

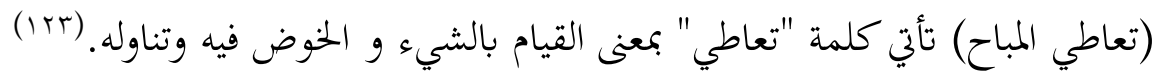

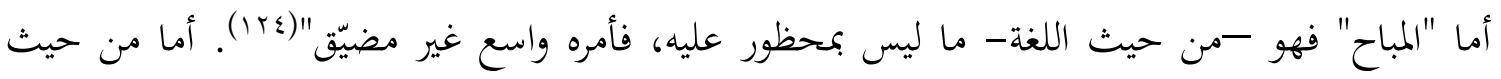

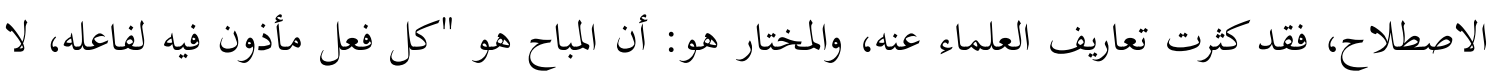

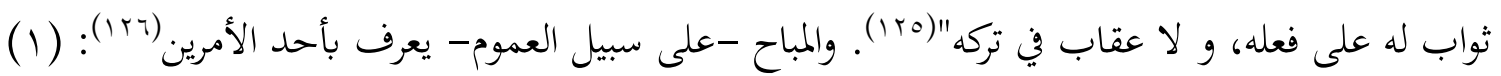

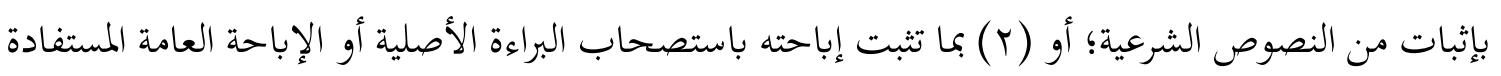

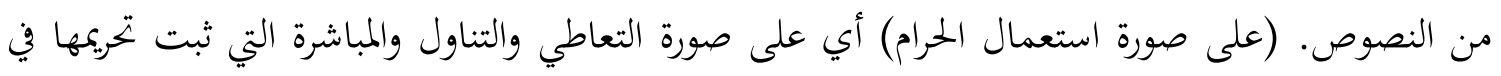
الشرع؛ ويكون ذلك بنية محرمة أو باستخدام طريقة تناول الأشياء المحرمة.

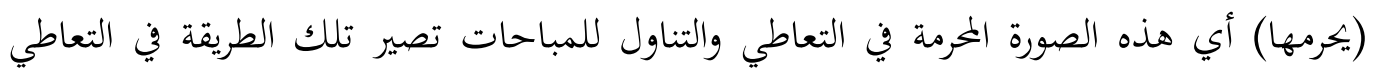
والتناول. وهذا التحريم كان بسبب النية السيئة في التعاطي والتناول للمباحات.

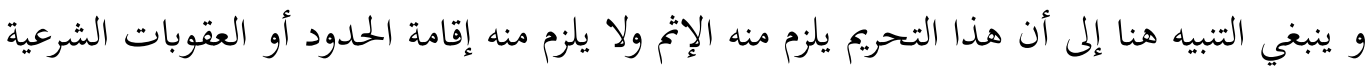

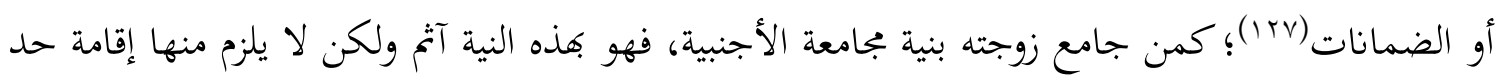
الزنا في حقه.

$$
\begin{aligned}
& \text { VI أنظر : ( Mr) }
\end{aligned}
$$

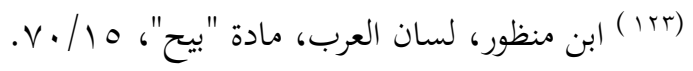

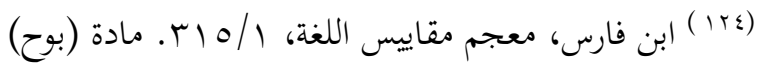

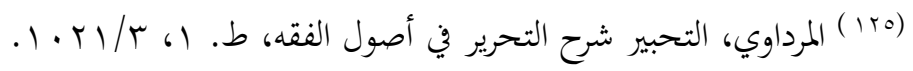

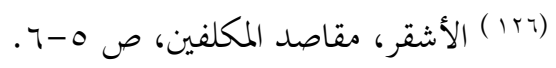

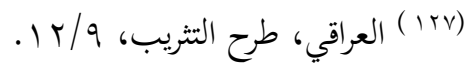


البصيرة: مجلة الدر اسات الإسلامية

AL-BASHIRAH: JOURNAL OF ISLAMIC STUDIES

Vol. 2 No. 1 (2021): 1-48

Website: https://journal.stiba.ac.id

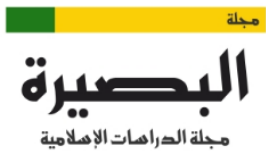

مجلة الدراهات الإهلامية

\section{AL-BASHIRAH}

JOURNAL OF ISLAMIC STUDIES

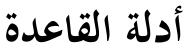

حديث أبي بكرة-رضي الله عنه- قال: "... فإنيّ سمعت رسول الله -صلّى الله عليه وسلّم- يقول: (إذا تواجه المسلمان بسيفيهما، فالقاتل والمقتول في النّار) قال فقلت: أو قيل: يا رسول الله هذا القاتل، فما

$$
\text { بال المقتول؟ قال: (إنّه قد أراد قتل صاحبه)"(1 (1). }
$$

فبيّن -صلى الله عليه وسلم- أن السبب في دخول المقتول النار أنه كان حريصا على قتل صاحبه.

فهذا المقتول نيته متوجهة لقتل من قتله، فلو أتيحت له الفرصة، وتمكن من قتل الآخر لقتله.

$$
\text { تطبيقات القاعدة: }
$$

ا - من استعمل ملكه ظانّا أنهّ لأجنبيّ ونحو ذلك، فإنّه يحرم عليه تعاطي ذلك اعتبارا

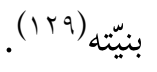

ץ- لو تعاطى شرب الماء، وهو يعلم أنّه ماء ولكن تعاطاه على صورة استعمال الحرام

$$
\text { كشرب الخمر صار حراما لتشبّهُه بالشّربة(·r أ). }
$$

ب- لو جامع أهله، وصوّر في ذهنه بجامعة من تحرم عليه، فجامع تلك الصّورة المرّمة، فإنّه

$$
\text { يحرم عليه ذلك وكلّ ذلك لتشبّهه بصورة الحرام(اrا). }
$$

\section{القاعدة السادسة: العزم المستقر مؤاخذ عليه(rrI)}

هذه القاعدة من القواعد المتفرعة تحت القاعدة الكبرى "الأمور بمقاصدها"؛ و هي قاعدة تتكلم عن أحد جزئيات أو أنواع القصد والإرادة الذي هو العزم المستقر لدى الإنسان. فإن القصد والإرادة ليسا على مرتبة أو درجة واحدة. فالقاعدة تبين و تؤسس: متى تكون النية والقصد مؤاخذ عليهما؟

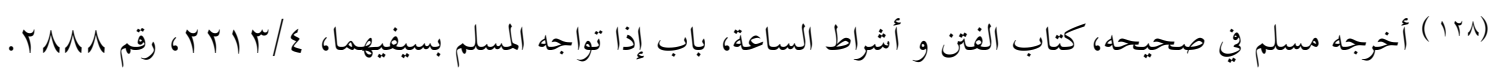

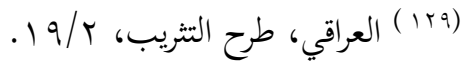

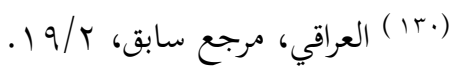

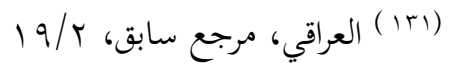

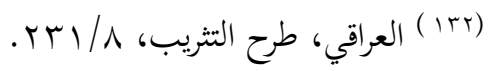


البصيرة: مجلة الدر اسات الإسلامية

AL-BASHIRAH: JOURNAL OF ISLAMIC STUDIES

Vol. 2 No. 1 (2021): 1-48

Website: https://journal.stiba.ac.id

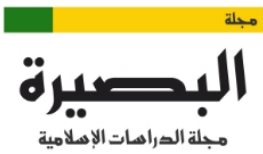

مجلة الدراهات الإهلامية

AL-BASHIRAH

JOURNAL OF ISI

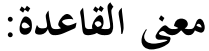

(العزم المستقر) أما العزم في اللغة، فهو: الجدّ(rr (1).ف"العزم" من حيث اللغة يدور على الصرامة والقطع واليقين وعدم التردد.

أما قوله (المستقرّ) فهو من الاستقرار و القرار، أي: الثبوت والسكون والتمكن والغاية والنهاية التي

لا تتجاوز حدودها(عَا). ف"المستقرّ" هو "الشيء الثابت الساكن المتمكن البالغ إلى غايته وفايته بحيث لا

$$
\text { يتجاوز ذلك الشيء عن حدودها بعد ذلك". }
$$

وعلى هذا، يمكن أن يقال في تعريف "العزم المستقرّ" من حيث الاصطلاح على أنه: الإرادة الصارمة القاطعة الجادة في القلب على القيام بأمر من الأمور بلا تردد.

(مؤاخذ عليه) أي: معاتب ومعاقب عليه. وأصل كلمة "مؤاخذ" من آخذ-يؤاخذ-مؤاخذة، فهو مؤاخذ، والمفعول مؤاخذ. "آخذ الرّجل" أي: عاتبه ولامه وعابه.

وعلى هذا، فيكون المعنى الإجمالي للقاعدة هو: "أن الإرادة الصارمة القاطعة الجادة المؤكدة في القلب للقيام بأمر من الأمور من دون أي تردد في القصد؛ يستحق المؤاخذة عليه، سواء كانت بالمعاتبة أو المعاقبة والمجازاة عليه".

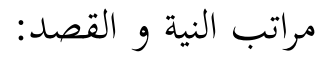

و لعله من المهم -و نحن نبحث عن هذه القاعدة- أن نشير إلى مراتب النية و القصد عند الفقهاء، لمعرفة موقع "العزم المستقر" من هذه المراتب. وقد حرّر الإمام السبكي -رحمه الله- مراتب القصد و كيف

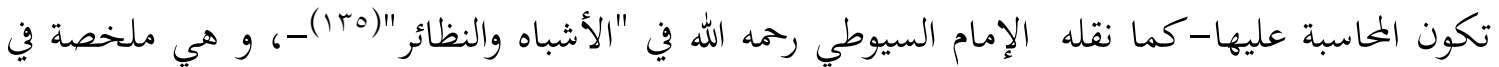

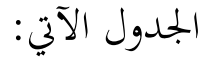

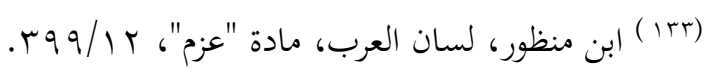

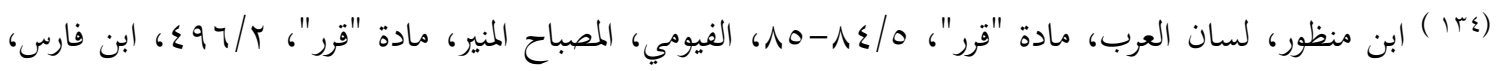

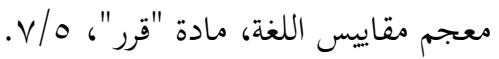

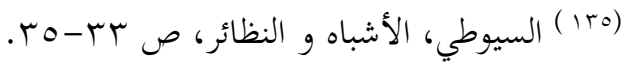


البصيرة: مجلة الدر اسات الإسلامية

AL-BASHIRAH: JOURNAL OF ISLAMIC STUDIES

Vol. 2 No. 1 (2021): 1-48

Website: https://journal.stiba.ac.id

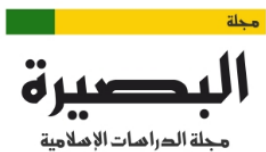

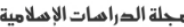

AL-BASHIRAH

JOURNAL OF ISLAMIC STUDISS

\begin{tabular}{|c|c|c|}
\hline الحكم - ت المي & 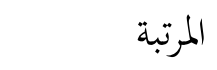 & 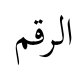 \\
\hline غير مؤاخذ عليه ولم يكتب لصاحبه الأجر & الهاجس & 1 \\
\hline مرفوع عنه ولم يكتب لصاحبه الأجر & الخاطر & r \\
\hline مرفوع عنه ولم يكتب لصاحبه الأجر & حديث النّفس & $r$ \\
\hline يكتب سميّم بالحسنة يكتب حسنة، والهمّ بالمسيّئة لا & الهمّ & $\varepsilon$ \\
\hline مؤاخذ عليه (على القول الراجح عند المحققين) & 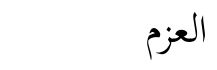 & 0 \\
\hline
\end{tabular}

و قد تكلم أيضا شيخ الإسلام ابن تيمية -رحمه الله- على هذا الموضوع بشيئ من التفصيل و

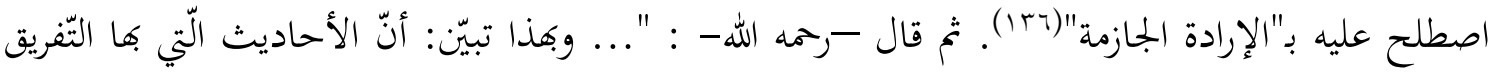

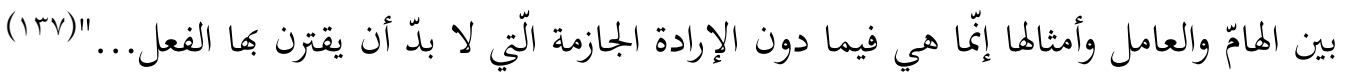

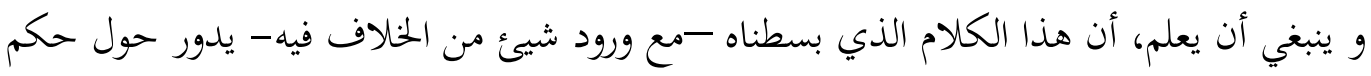

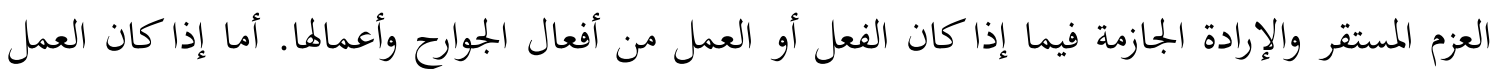

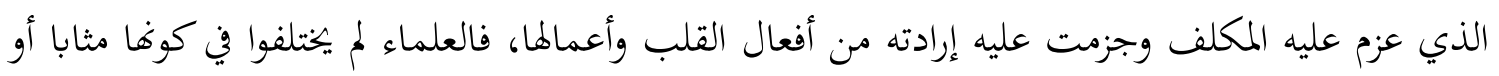
معاقبا عليه (1+1).

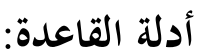

وقد وردت أدلة الشرع بالمؤاخذة بعزم القلب المستقر، قرآنا وسنة وإجماعا. أما من القرآن:

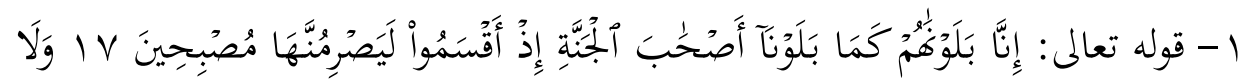

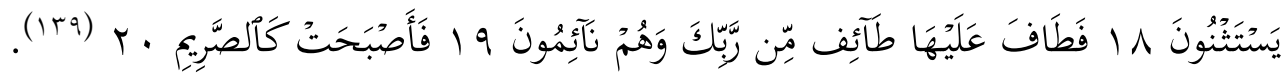

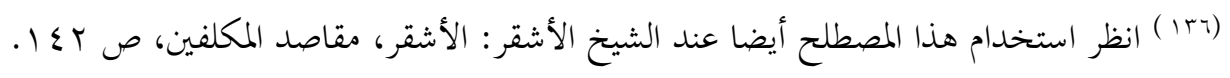

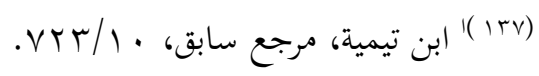

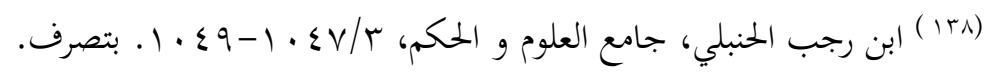

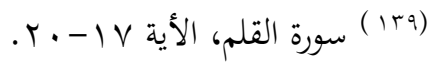


قال القرطبي -رحمه الله-: "في هذه الآية دليل على أنّ العزم مثّا يؤاخذ به الإنسان، لأغّّم عزموا على أن يفعلوا فعوقبوا قبل فعلهم"(.؛ (1).

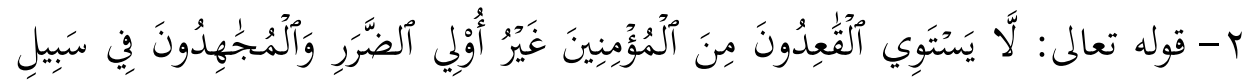

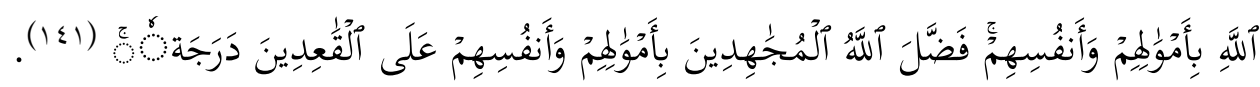

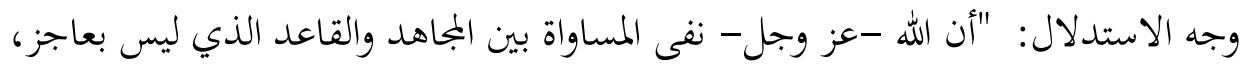

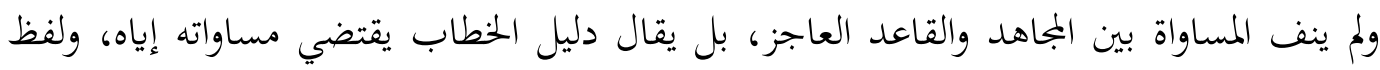

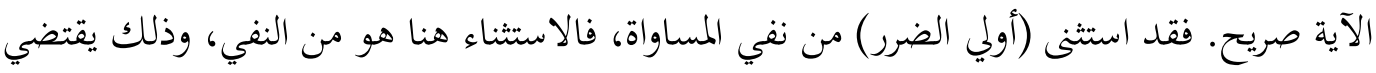

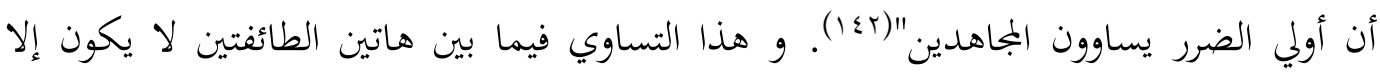
لاعتبار العزم المستقر في نفس أولي الضرر القاعدون العاجزون عن المشاركة في الجهاد؛ وهم بهذا العزم يجصلون ما يكصل عليه المشاركون في الجهاد.

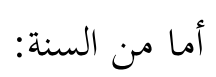

1- قول النبي -صلى الله عليه و سلم- : "إذا التقى المسلمان بسيفيهما فالقاتل والمقتول

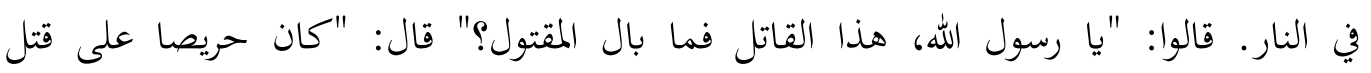

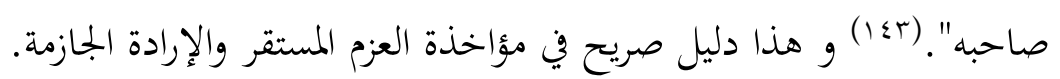

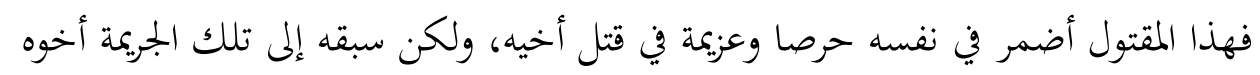
القاتل، وإلا فإنه سيصير هو القاتل. فهو معذب في النار ليس بسبب قيامه بفعل القتل، ولكن بسبب عزمه وحرصه على قتل أخيه.

وقال شيخ الإسلام ابن تيمية -رحمه الله- في وجه استدلاله بهذا الحديث:"....وكذلك الحك

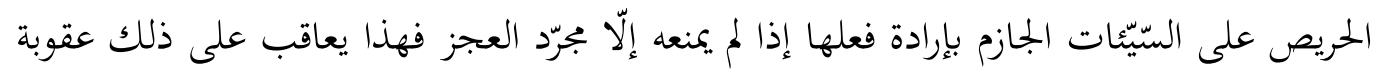

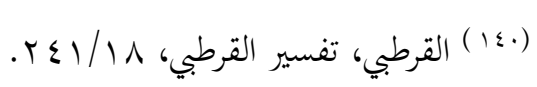

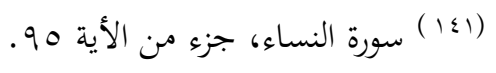

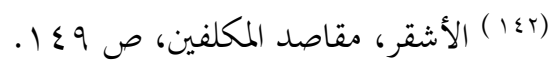

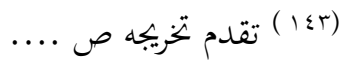


الفاعل لحديث أبي كبشة(؛؛) ولما في الحديث الصّحيح (إذا التقى المسلمان بسيفيهما فالقاتل

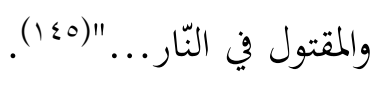

ץ- حديث سهل بن حنيف -رضي الله عنه- عن النبي صلى الله عليه وسلم قال: (من

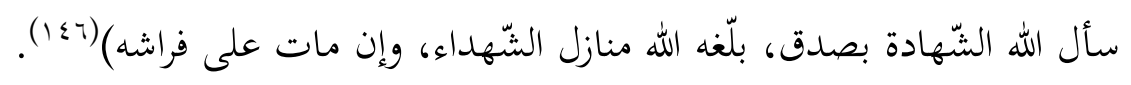

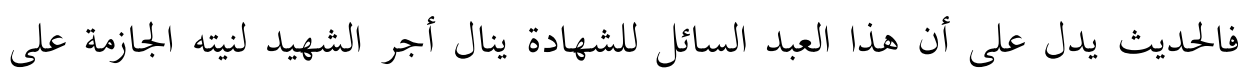

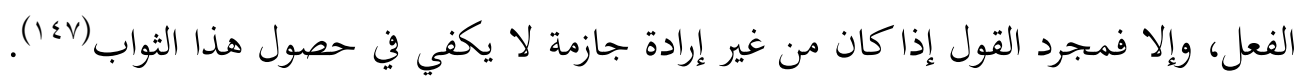

$$
\text { من الإجماع: - n }
$$

وقد نقل بعض العلماء الإجماع على المؤاخذة بأعمال القلوب وعزمها. من ذلك ما يقوله الإمام

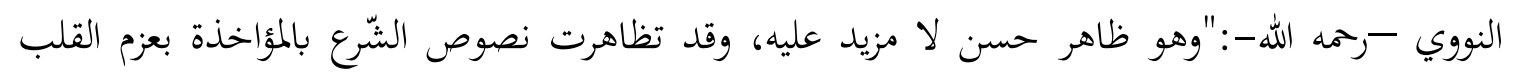

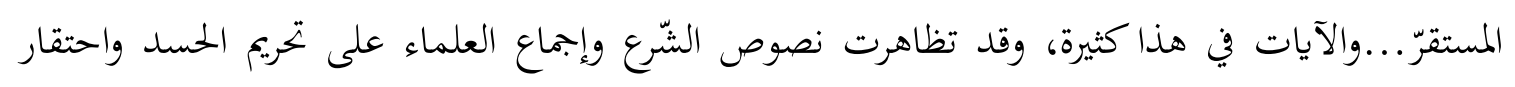

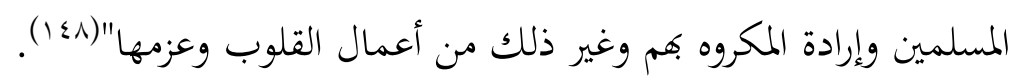

ونقل أيضا هذا الإجماع الإمام السيوطي -رمهه الله-، فقال: "... واحتجوا أيضا بالإجماع على

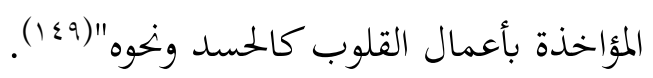

(\{ (1) ) و هو قوله عليه الصلاة و السلام: (...ورجل آتاه الله علما ولم يؤته مالا، فهو يقول: "لو كان لي مثل مال هذا عملت

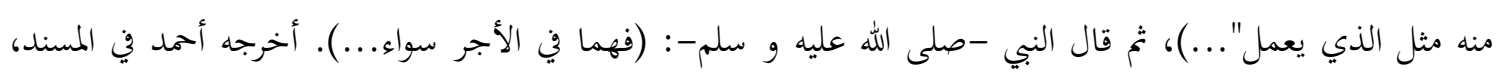

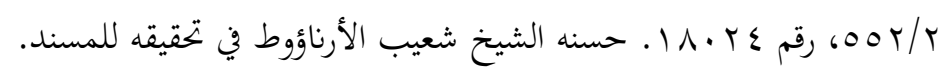

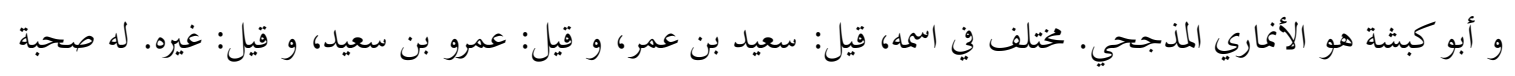

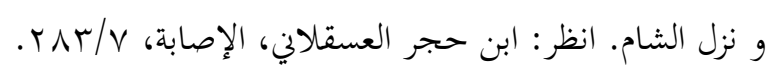

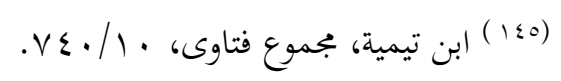

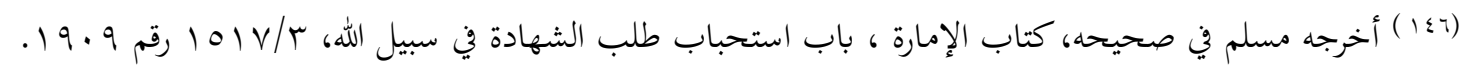

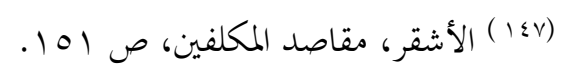

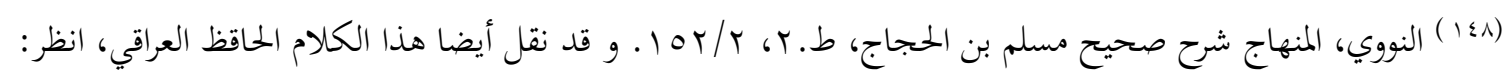

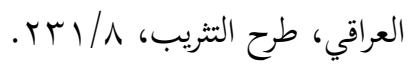

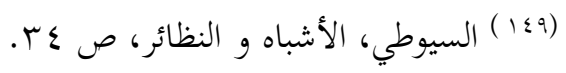


البصيرة: مجلة الدر اسات الإسلامية

AL-BASHIRAH: JOURNAL OF ISLAMIC STUDIES

Vol. 2 No. 1 (2021): 1-48

Website: https://journal.stiba.ac.id

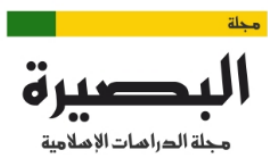

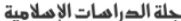

AL-BASHIRAH

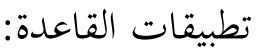

1- - من اقترض مالا من غيره يلزمه العزم على قضاءه. ويكرم عليه اقتراض مال الغير

$$
\text { بنية عدم رده إليه، ومن فعل ذلك أتلفه الله عز وجل. (10.) }
$$

r- الصلاة لا تبطل بالتردّد -على القول الراجح-؛ وذلك لأن الأصل بقاء النيّة ولأن

التردد ليس عزما فلا يؤاخذ عليه. فالتردّد هذا لا يبطلها؛ فما دام أنه لم يعزم على القطع فهو باق على نيّته، ولا يمكن أن نقول: إن صلاتك بطلت للتردّد في قطعها(101).

r- - إذا عزم الإنسان على مبطل من مبطلات الصلاة ولم يفعله، مثل: "إذا عزم على

أن يتكلّم في صلاته ولم يتكلّم، أو عزم على أن يحدث ولم يحدث، فقال بعض العلماء: إنها تبطل،

لأن العزم على المفسد عزم على قطع الصّالاة، والعزم على قطع الصّالاة مبطل لها"(10 أ.

$$
\text { ظن مستثنيات القاعدة }
$$

ا- - الطّلاق لا يقع إلّا بلفظ، فلو نواه بقلبه من غير لفظ، لم يقع في قول عامّة أهل

العلم؛ منهم عطاء، والشّافعيّ، وإسحاق؛ "لأنّه تصرّف يزيل الملك، فلم يكصل بالنّيّة كالبيع والهبة.

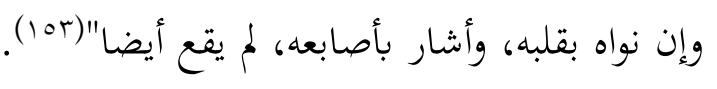

r- - جميع العبادات تبطل بالعزم على القطع - - كما تقدم- إلا الحجّ والعمرة، "فإن

الحجّ والعمرة لا يبطلان بإبطالمما؛ حتى لو صرّح بذلك وقال: إي قطعت نسكي، فإنه لا ينقطع

$$
\text { ولو كان نفالا..." (10). }
$$

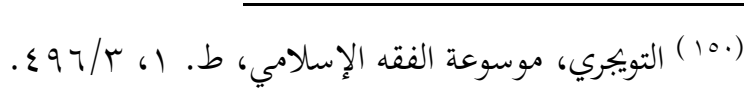

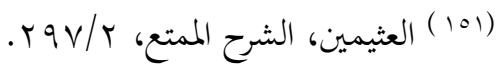

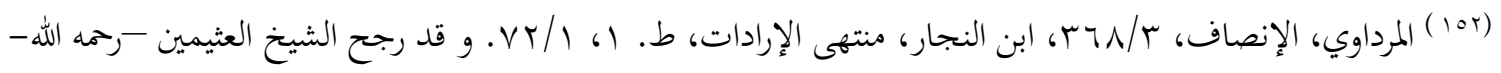

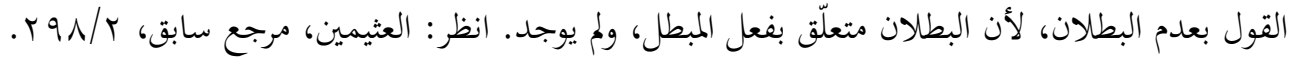

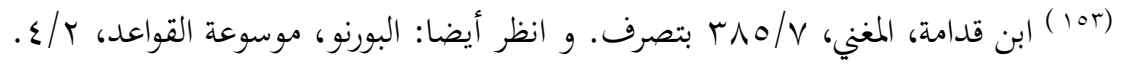

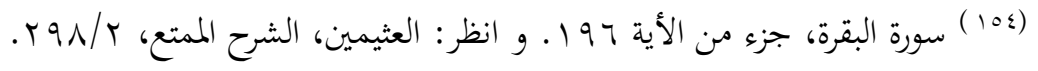


البصيرة: مجلة الدر اسات الإسلامية

AL-BASHIRAH: JOURNAL OF ISLAMIC STUDIES

Vol. 2 No. 1 (2021): 1-48

Website: https://journal.stiba.ac.id

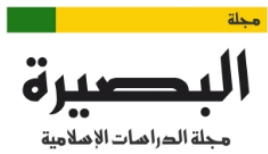

مجلة الدراهات الإهلامية

AL-BASHIRAH

القاعدة السابعة: الخواطر و حديث النفس والوساوس مرفوعة عن هذه الأمة(100) هذه القاعدة تعتبر قاعدة مكملة للقاعدة التي تقدمت، وهي قاعدة "العزم المستقر مؤاخذ عليه". فقاعدة هذا المطلب تتكلم عن جزئية أخرى من جزئيات القصد والنية؛ وهي "الخواطر وحديث النفس والوساوس".

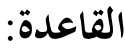

$$
\text { أما "الخواطر" فهي جمع "خاطر"، وهو "ما يخطر في القلب من تدبير أو أمر"(107). }
$$

ومن حيث الاصطلاح، فهو "ما يرد على القلب من الخطاب أو الوارد الّذي لا عمل للعبد فيه"(10v)

أو "ما يجري في النفس تم يذهب في الحال بلا تردد"(101). وهو في الغالب يكون عند اليقظة، بخلاف الرؤيا(109). أما "حديث النفس" فهو متقارب المعنى -إن لم يكن نفس المعنى-مع كلمة "الوساوس". و "الوساوس" هي الوسوسة والوسواس، و هي في اللغة: الصّوت الخفيّ من ريح ونحوه. والوسوسة والوسواس بالكسر - حديث النّفس.

قال الفيروز آبادي -رحمه الله-:"والوسوسة: حديث النّفس والشّيطان بما لا نفع فيه ولا خير"(.7 (1). (مرفوعة عن هذه الأمة) أي أن أي فرد من أفراد هذه الأمة إذا وقع منه خاطر أو حديث النفس أو وسوستها للشر أو المعصية فإنه غير مؤاخذ عليه، فلا يكون آثما به.ولقد سبق لنا الإشارة إلى مراتب القصد والنية في القاعدة السابقة. وحكم هذا النّوع وما كان أضعف منه أنّه مرفوع عن هذه الأمّة، فلا إثم فيه إن لم يقترن به عمل أو قول، كمن حدّث نفسه أن يسرق أو يخون(17) .

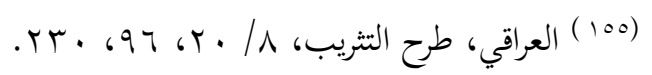

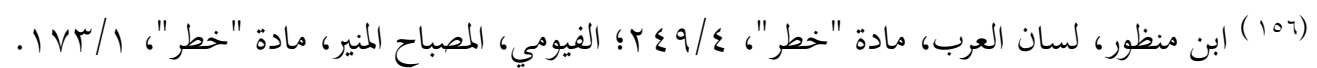

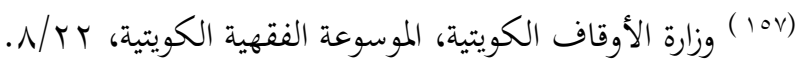

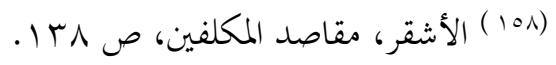

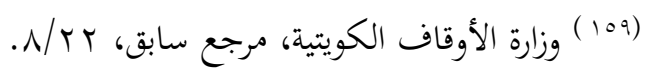

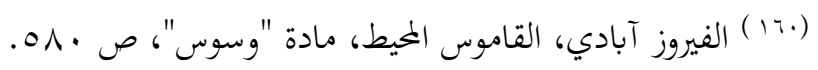

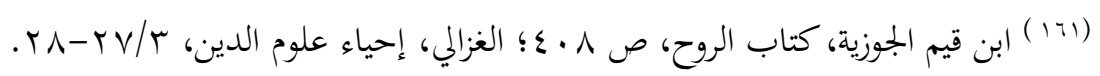


البصيرة: مجلة الدر اسات الإسلامية

AL-BASHIRAH: JOURNAL OF ISLAMIC STUDIES

Vol. 2 No. 1 (2021): 1-48

Website: https://journal.stiba.ac.id

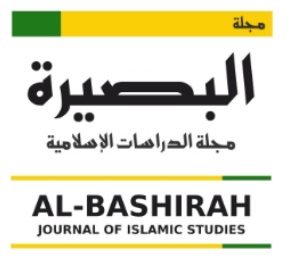

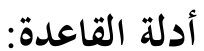

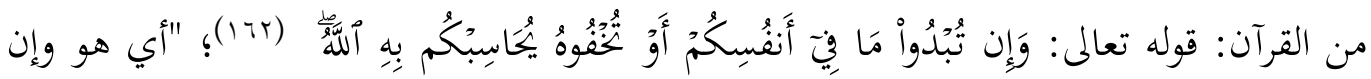

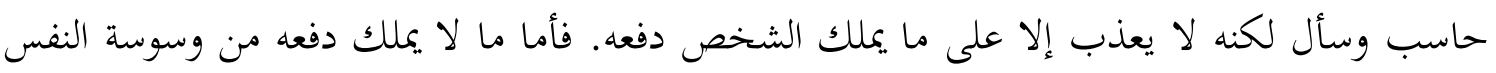

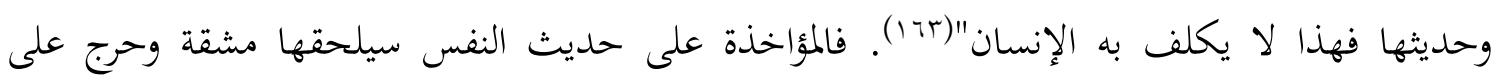

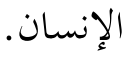

أما من السنة: فعن أبي هريرة -رضي الله عنه-عن النّبّ -صلّى الله عليه وسلّم- قال: (إنّ الله بحاوز

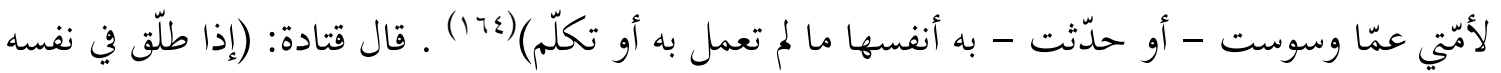
فليس بشيء). فقد ذكر كثير من أهل العلم أنه محمول على ما لم يستقر في القلب. قال النووي -رحمه الله-

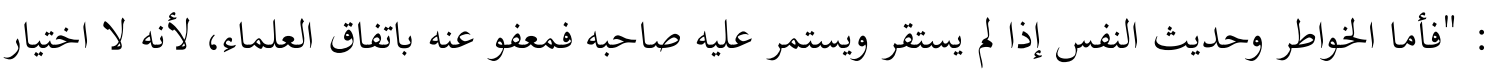

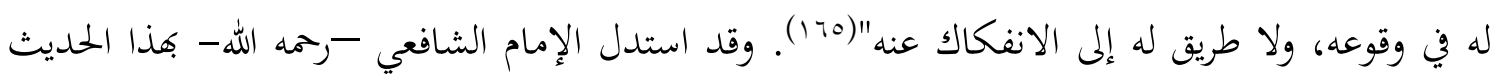

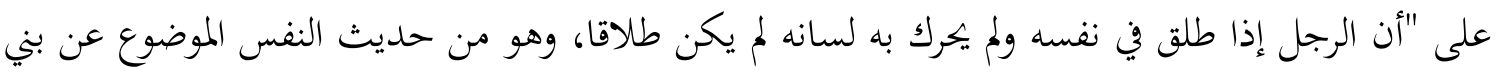

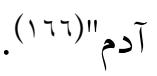

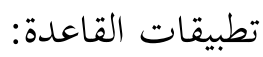

1- المبتلى بالوسواس لا يقع طلاقه حتى لو تلفظ به بلسانه إذا لم يكن عن قصد، لأن

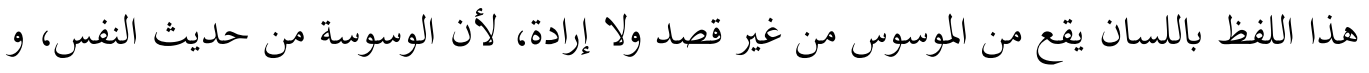

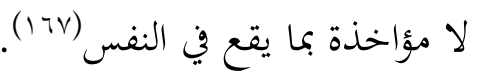

$$
\begin{aligned}
& \text { T人 }
\end{aligned}
$$

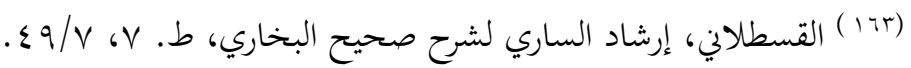

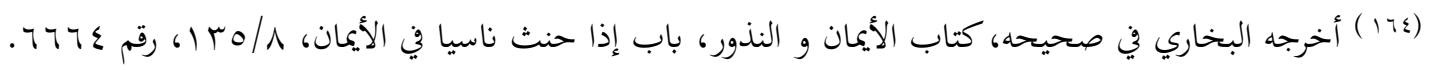

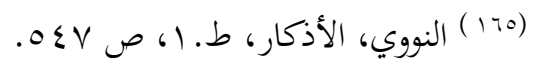

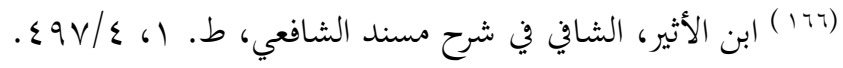

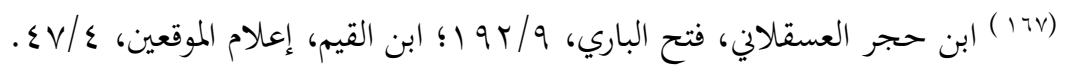


r - " - بكون الإنسان في صلاته ويحدّث نفسه؛ يقول مثلا: مررت على فلان، وسلمت

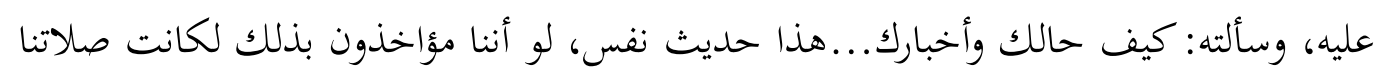

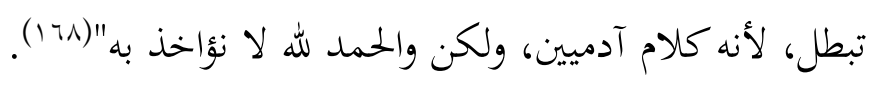

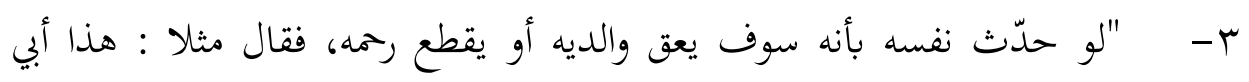

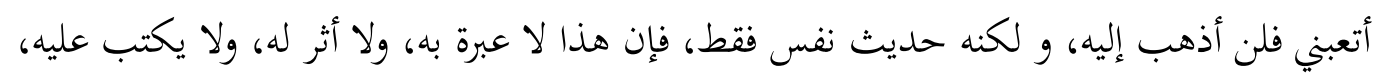

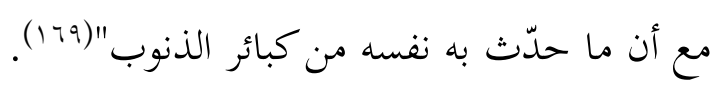

القاعدة الثامنة: الكافر و المرتد ليسا من أهل النية(IV.) ليس كل إنسان يصلح لأن يكون من أهل النية؛ بمعنى آخر : أن هناك أمورا بتعل النيات غير النها معتبرة شرعا. من هذه الأمور: الكفر والردة.

فهذه القاعدة تبين موقع من وقع في الكفر أو الردة من النية و القصد: هل نياتم و مقاصدهم معتبرة

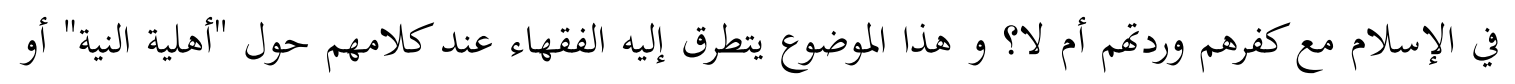

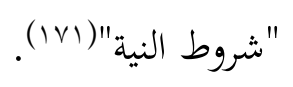

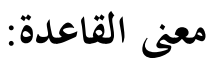

(الكافر والمرتد) لفظ "الكافر" من الكفر، والكفر لغة: الستر والتغطية(IVr). وتعريف الكفر شرعا:

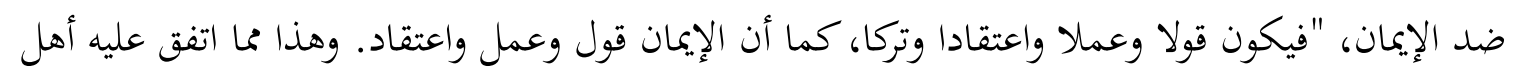

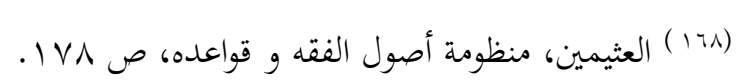

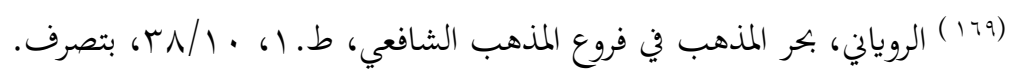

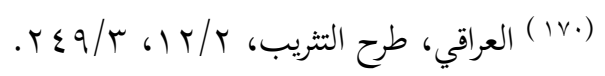

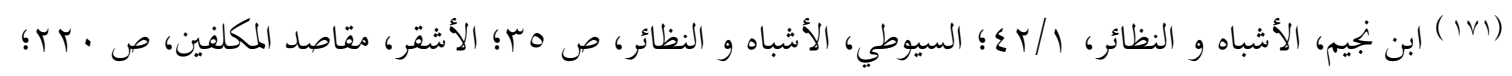

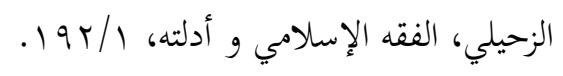

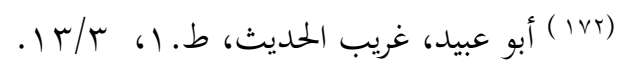


السنة والجماعة، خلافا لمن حصر الكفر في التكذيب أو الجحود بالقلب أو بالقلب واللسان، ونفى أن يكون

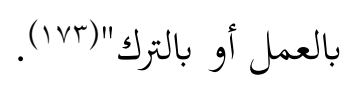

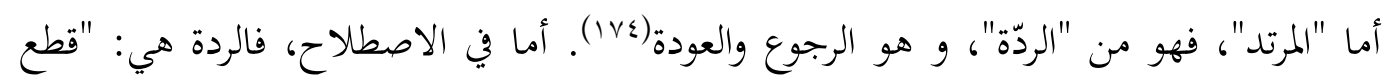

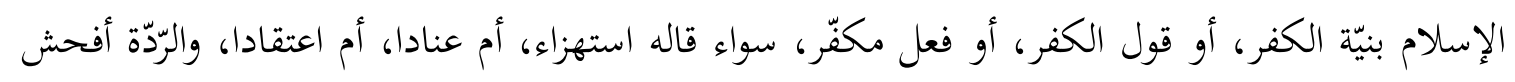

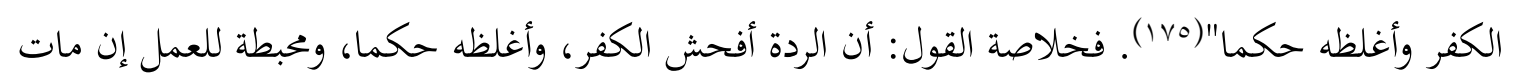

$$
\text { ولم يتب منها. }
$$

(ليسا من أهل النية) أي أن الكافر والمرتد لا يملكان أهلية النية، لأن من شروط أهلية النية: الإسلام؛

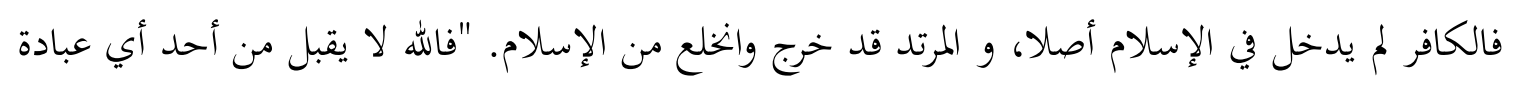

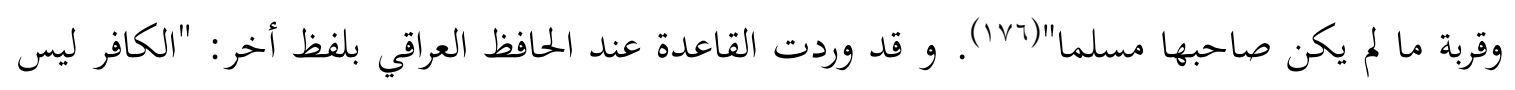

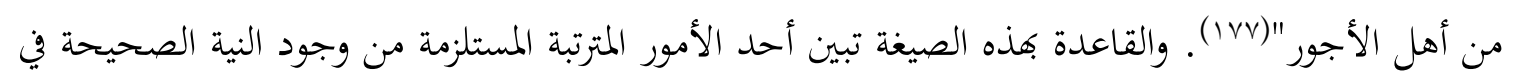

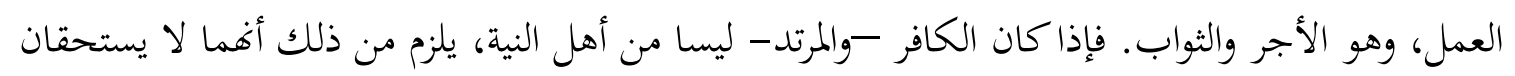

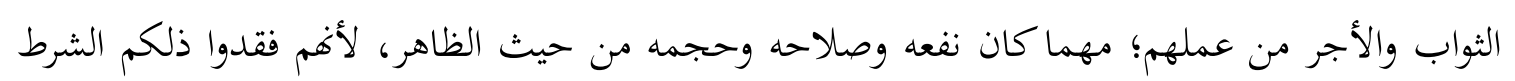

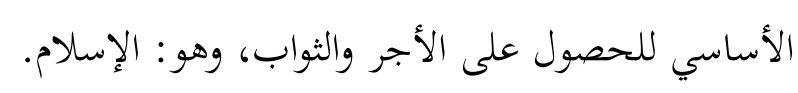

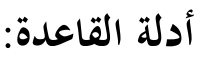

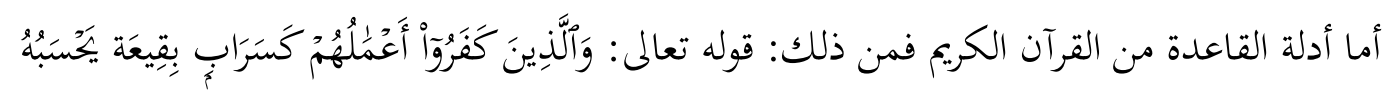

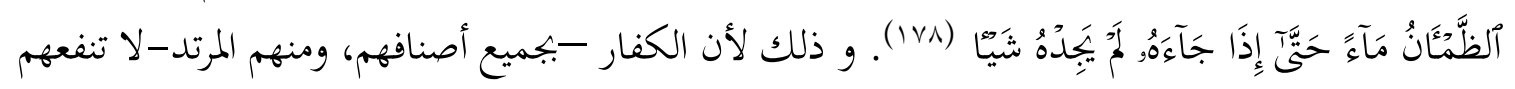
نياتم ومقاصدهم الصالحة في عباداقم ومعاملاتم في ترتّب القبول عند الله والثواب منه تعالى؛ لأفم أصلا

( ) السقار، التكفير و ضوابطه، د.ط، ص و 9؛ موقع الدرر السنة، الموسوعة العقدية، http://www.dorar.net/enc/aqadia/3235

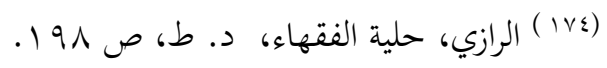

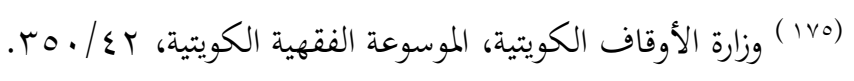

$$
\begin{aligned}
& \text { ا }
\end{aligned}
$$

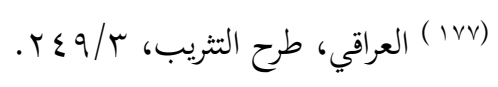

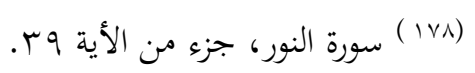


ليس أهلا للنية(1V9).فمآل أعمال المرتدين، وهو الحبوط و البطلان والفساد وعدم الاعتبار بأعماهم، فلم

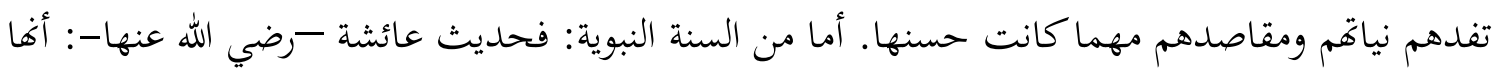

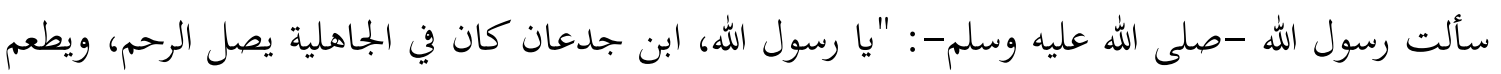

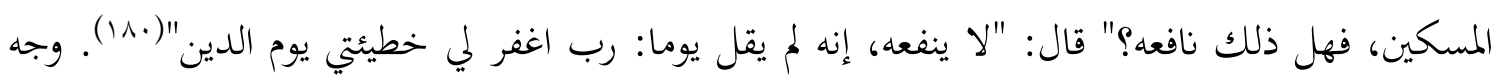

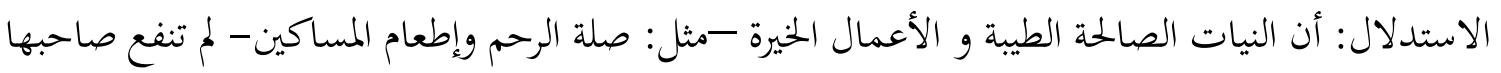

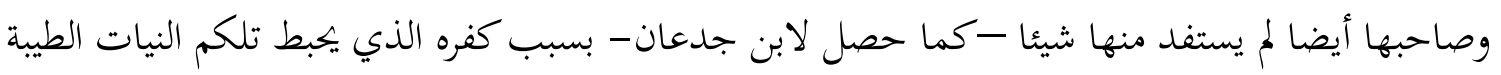

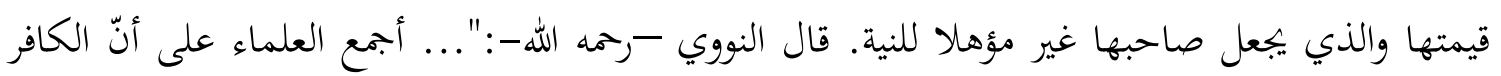

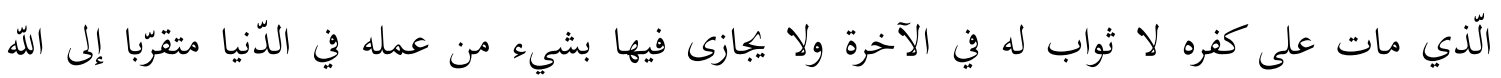
تعالى... "111)".

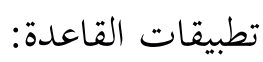

- - لا يصح وضوء الكافر ولا غسله؛ لأنه غير أهل للنية، وهذا قول الجمهور (r/1). يعني إذا

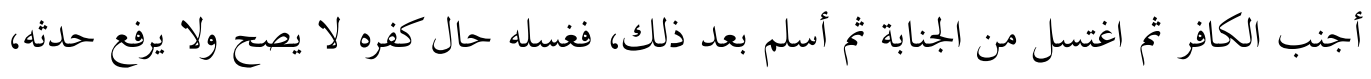
لأنه اغتسل بدون نية؛ لأنه ليس من أهل النية.

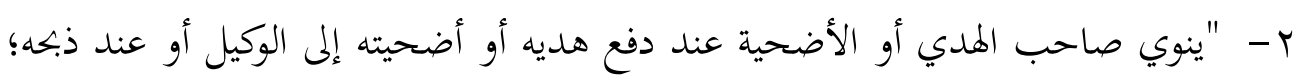

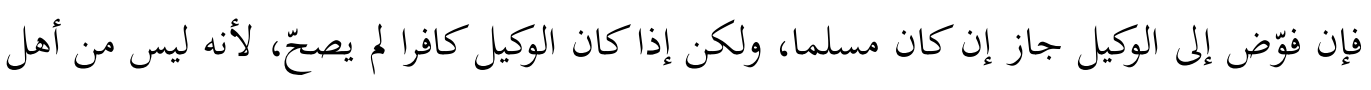

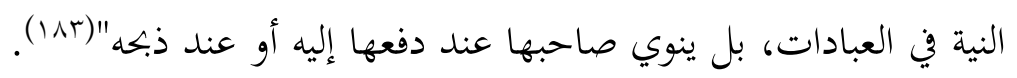

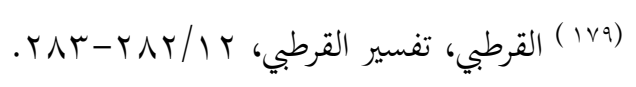

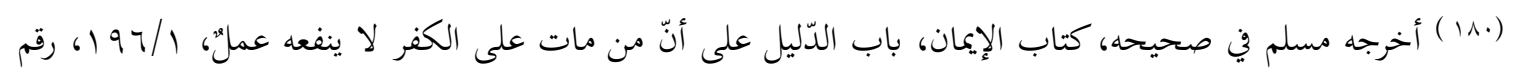

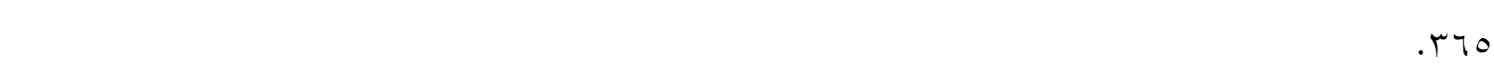

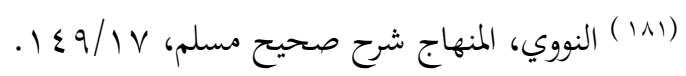

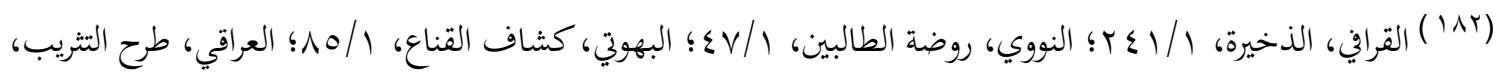

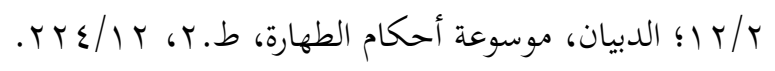

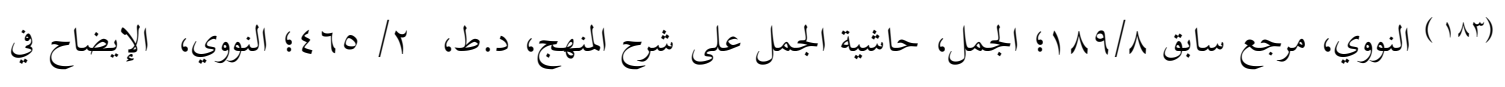

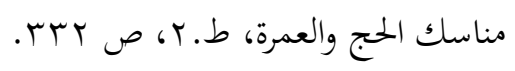


البصيرة: مجلة الدر اسات الإسلامية

AL-BASHIRAH: JOURNAL OF ISLAMIC STUDIES

Vol. 2 No. 1 (2021): 1-48

Website: https://journal.stiba.ac.id

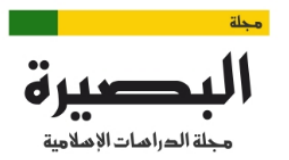

AL-BASHIRAH

r- - لو أذّن الكافر أو المرتد، فإنه لا يصح و لا يقبل منهما، لأفما ليسا من أهل النية و لا

$$
\text { مستثنيات القاعدة للعبادة. }
$$

1- الزكاة من أهل الذمة: استثنى كثير من العلماء كالشافعي وأبي حنيفة وأحمد نصارى بني

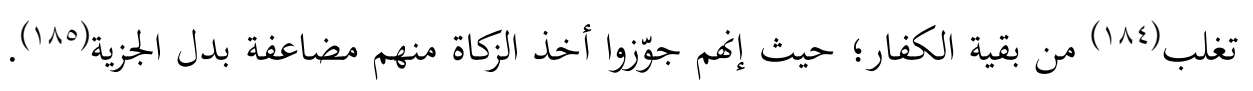

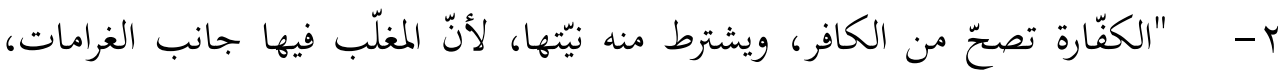

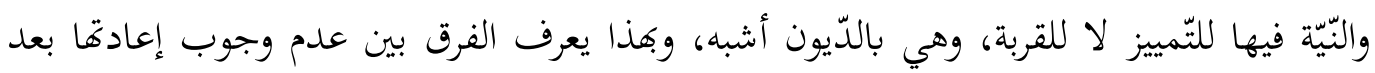

$$
\text { الإسلام ووجوب إعادة الغسل بعده"(101). }
$$

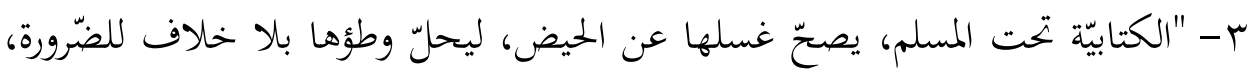

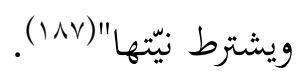

\section{القاعدة التاسعة: الجممل في القول تفسره النية(1) (1)}

هذه القاعدة ترشدنا إلى واحد من وظائف النية و القصد في فهم كلام الناس، خاصة في مجال المعاملات. والوظيفة المقصودة هي تفسير القول المجمل -كما سيأتي بيانه إن شاء الله-.

(1) ( ) هم قبيلة عظبمة تنتسب إلى تغلب بن وائل بن قاسط بن هنب بن أفصى بن دعمى بن جديلة بن أسد بن ربيعة بن

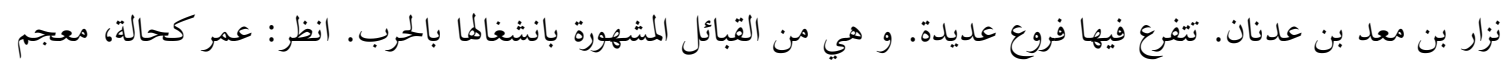

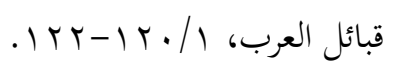

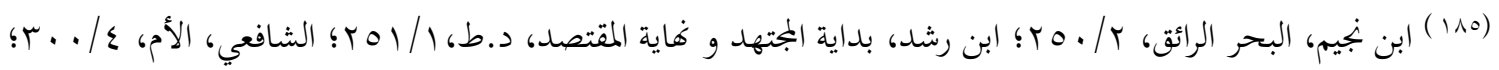

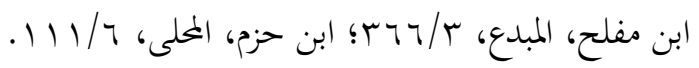

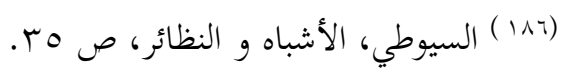

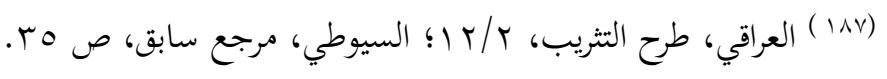

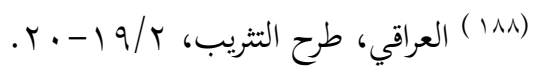


البصيرة: مجلة الدر اسات الإسلامية

\section{AL-BASHIRAH: JOURNAL OF ISLAMIC STUDIES}

Vol. 2 No. 1 (2021): 1-48

Website: https://journal.stiba.ac.id

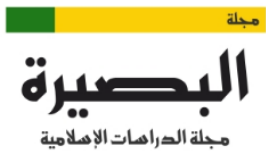

مجلة الدراهات الإهلامية

AL-BASHIRAH

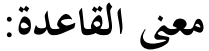

(المجمل في القول) فالمجمل في اللغة: المجموع، أي: مجموع من غير تفصيل. و يأتي أيضا بمعنى "المبهم"(1)(1). أما في الاصطلاح، فمن تعريفاته: هو "ما يتوقف فهم المراد منه على غيره إما في تعيينه أو بيان صفته أو مقداره"( (19.) (19)

و(الإجمال) المراد في القاعدة أعم من هذه الصور الثلاثة المذكورة في التعريف؛ حيث يشمل أنواع الغموض في القول؛ صريحه وكنايته. وهي -أي القاعدة- متماشية مع قاعدة: (مقاصد اللفظ على نية اللافظ إلا في اليمين عند القاضي)(191) وقاعدة ( اللفظ الصريح يحتاج إلى نية)(r9) وقاعدة (الكناية مفتقرة إلى والى النية)(بوا)؛ حيث إن النية في الصريح والكناية تأتي دورها لبيان مراد المتكلم أو القائل للقول والكاملام. (تفسره النية) أي أن النية تفسر وتبين وتوضح وجه الإجمال والإهمام والغموض في ذلك القول؛ سواء كان ببيان مراده أو بيان صفته أو بيان مقداره أو من باب تقييده وتخصيصه؛ حيث إن الإجمال الحاصل في الكلام يمكن أن يفسر ويبيّن بالرجوع إلى نية المتكلم أو المتلفظ بالقول. قال العلامة الباحسين -حفظه الله-:"أن معاني الألفاظ و ما يراد به منها يفسر وفق إرادة و نية من نطق بها، نظرا لأن الألفاظ تحتمل تفسيرات متعددة، و هي قابلة للتخصيص إن كانت عامة، و للتقييد إن مطلقة، و للإجمال، و لطائفة من التأويلات، و لذلك فإن الناطق بها هو أدرى بما أراده من قوله..."(؟19).

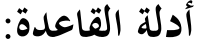

محا يستدل لهذه القاعدة: حديث عمر بن الخطاب -رضي الله عنه-: (إنّا الأعمال بالنّيّات، وإنّما لكلّ امرئ ما نوى، فمن كانت هجرته إلى دنيا يصيبها، أو إلى امرأة ينكحها، فهجرته إلى ما هاجر إليه).

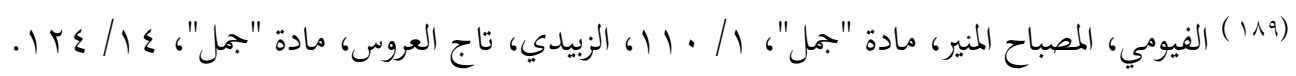

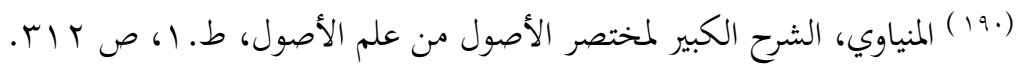

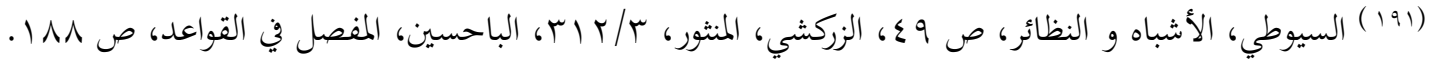
(rوا ) مع أن الأصل: (الصريح لا يحتاج إلى نية)، و لكن إذا ظهر أن المقصود من الكلام بخلافه، فحينئ احتاج إلى نية تبين

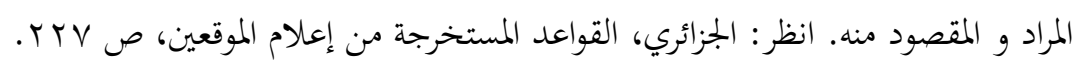

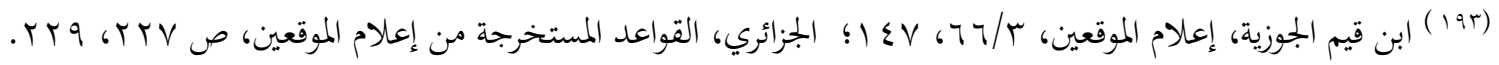

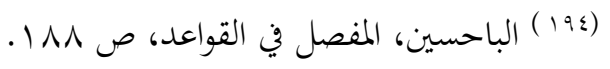


قال ابن القيم كرمه الله-مبيّنا معنى هذا الحديث:" فبيّن (أي: الرسول) في الجملة الأولى أنّ العمل

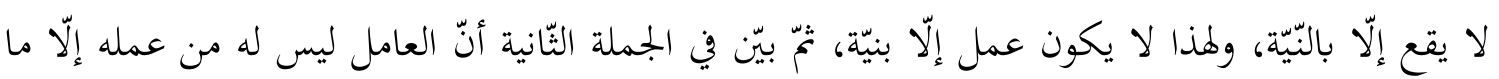

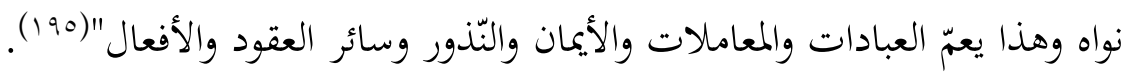

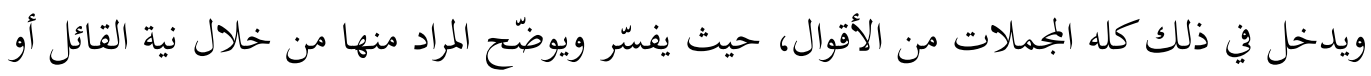

1- "من حلف أنه لا يدخل دار فلان مثلا وأراد في شهر كذا أو سنة كذا أو حلف لا

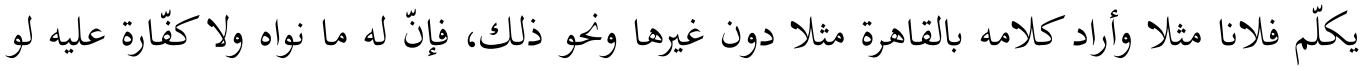
خالف ظاهر اللّفظ مع موافقة النّيّة"(191). r- "اشتراط النّيّة في الكنايات التّي ينعقد بها البيع، والكناية في الطّلاق، وذلك؛ لأنّ النّا

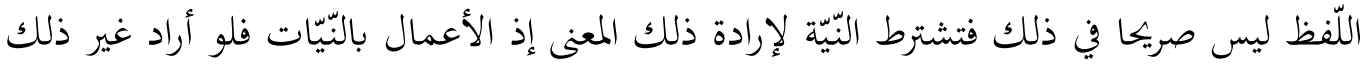

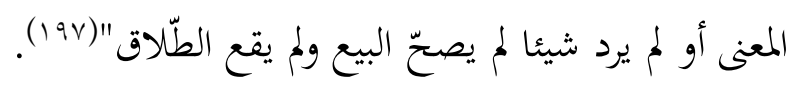

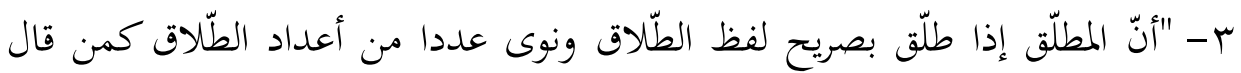

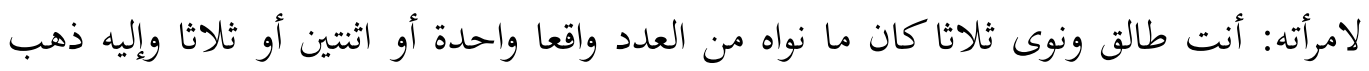

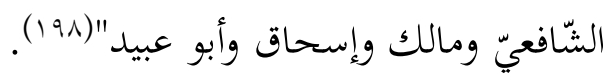

القاعدة العاشرة: من استعجل ما أمر بتأخيره ووعد به، حوم عنه عند ميقاته(199)

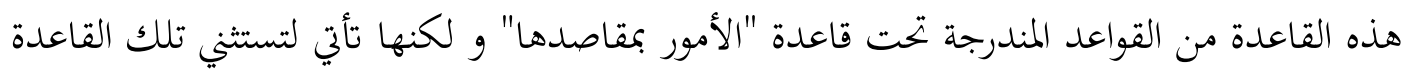
الكبرى وهي أيضا ذات علاقة وثيقة مع قاعدة "سد الذرائع" حيث إفا تمنع طريق صاحب النية الفاسدة.

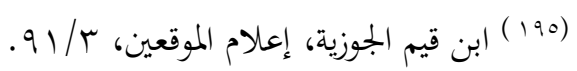

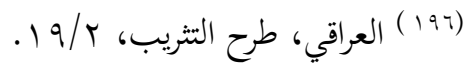

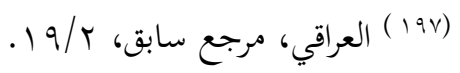

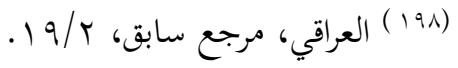

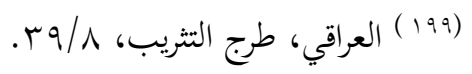


البصيرة: مجلة الدر اسات الإسلامية

AL-BASHIRAH: JOURNAL OF ISLAMIC STUDIES

Vol. 2 No. 1 (2021): 1-48

Website: https://journal.stiba.ac.id

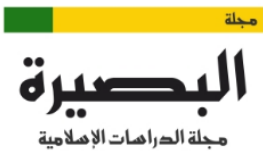

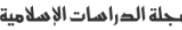

AL-BASHIRAH

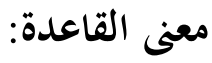

(من استعجل ما أمر بتأخيره ووعد به) فالاستعجال لغة من "العجل"، وهي كلمة تدل على

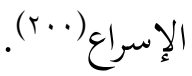

فمعنى هذه الصيغة: أن الإنسان الذي تسرّع في حصول ما سيكون من حقه وما وعد به مستقبلا -وليس حالا-، و هو من أجل الحصول على ذلك الحق والوعد لا بد أن يسلك طريقا محرما ووسيلة ممنوعة شرعا، فإن ذلك الحق والوعد:

(حرم عنه عند ميقاته) أي أن الشرع عامله بنقيض مقصوده ونيته في موعده، فيحرم من ذلك الحق

$$
\text { والوعد بسبب استعجاله للحصول والوصول إليه قبل موعده. }
$$

فالفاعل هنا يعامل ويعارض بنقيض مقصوده، وذلك لأن مقصد الفاعل من فعله كان تحايلا على الشرع من جانب، أو استعجالا لأمر مستحق أو مباح من جانب آخر بفعل أمر محرم، ولذلك أهمل قصد الفاعل وعومل بنقيض ما قصد عقوبة له وزجرا لغيره، إلى جانب العقوبة المستحقة على الفعل نفسه(ب(r). وقد وردت القاعدة بعدة صيغ مع اتحاد المعنى والمراد. من هذه الصيغ -مثلا-: "من استعجل الشيئ قبل أوانه عوقب بحرمانه"(r.r)، و "من تعجل حقه أو ما أبيح له قبل وقته على وجه محرم عوقب بحرمانه"(r.r). وقد دخلت هذه القاعدة -من حيث تطبيقاتها- في باب السياسة الشرعية وسد الذرائع -كما تقدم-. وقد قال ابن قيم الجوزية -رحمه الله-: "وقد استقرت سنة الله في خلقه شرعا وقدرا على معاقبة العبد

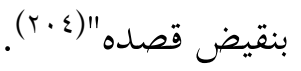

أدلة القاعدة:

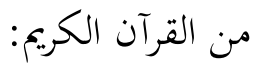

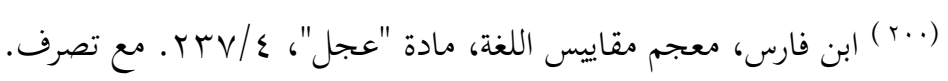

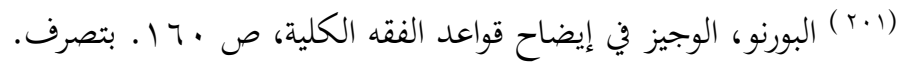

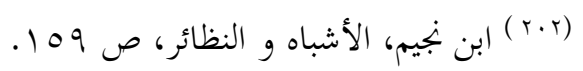

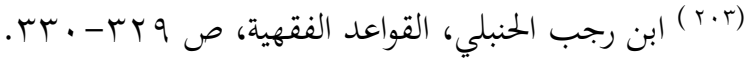

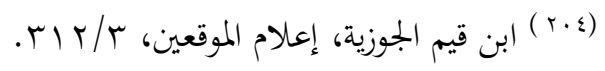




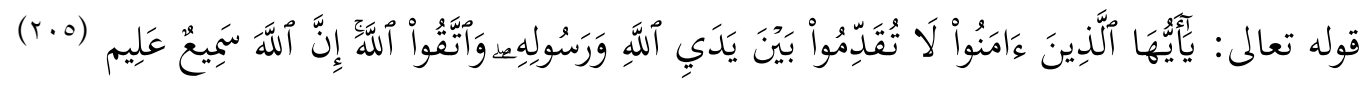

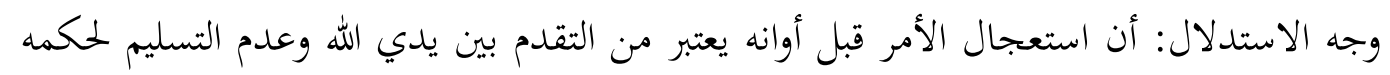

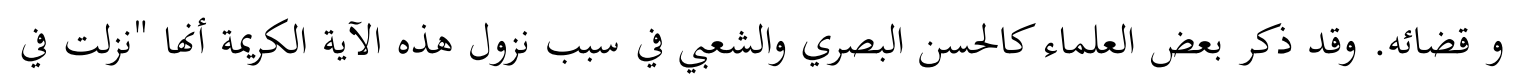

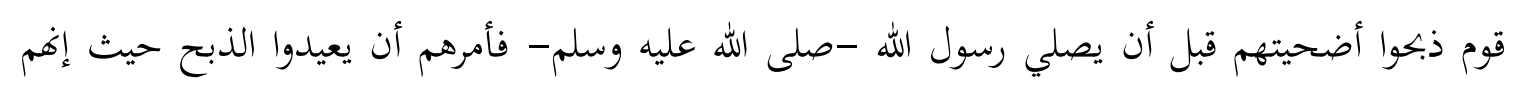
استعجلوا الذبح قبل وقته المحدد شرعا فكان لغوا ولم يعتبر "(r.r).

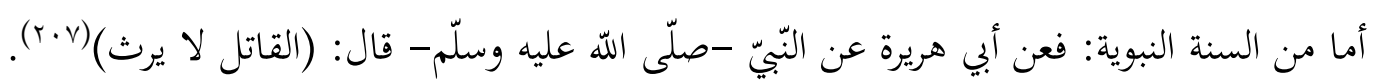

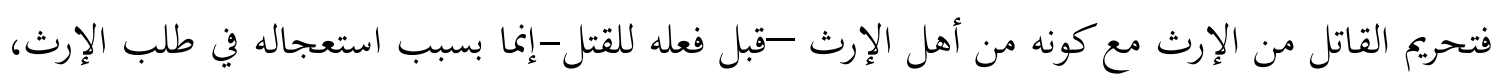
فيعاقب بحرمان الإرث عنه(r) (r). كذلك ما روي عن عبد الله بن عمر -رضي الله عنهما-أنّ رسول الله -صلّى الله عليه وسلّم - قال:

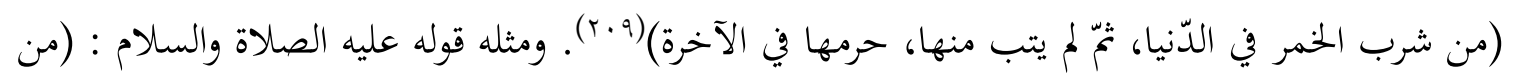

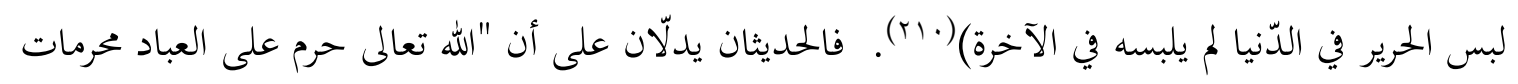

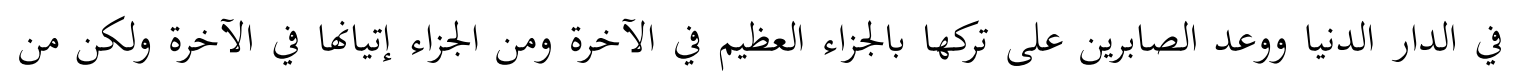

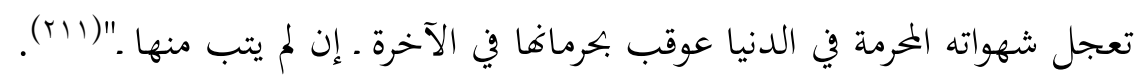

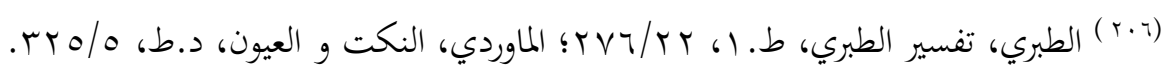

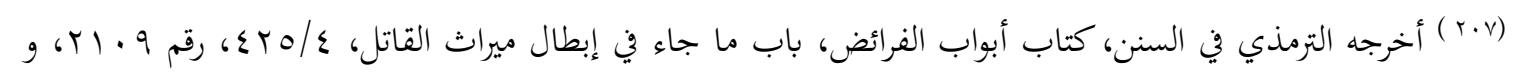
صححه الألباني.

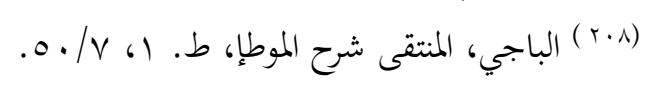

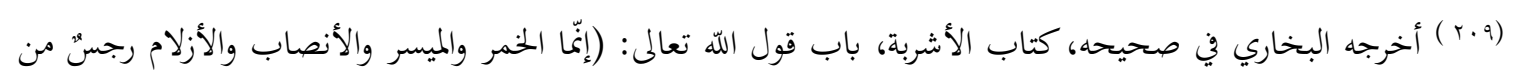

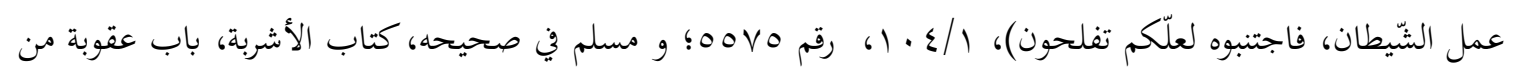

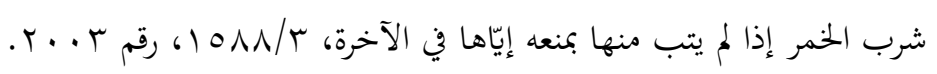

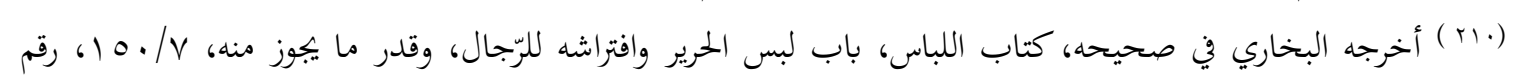
$.0 N 4 t$ (ril) الركابي، القاعدة الفقهية : (من تعجّل شيئاً قبل أوانه عوقب برمانه) وأمثلة ومناذج من الواقع، مقالة تنشر في: . http://islamancient.com/play.php?catsmktba=2450 
البصيرة: مجلة الدر اسات الإسلامية

AL-BASHIRAH: JOURNAL OF ISLAMIC STUDIES

Vol. 2 No. 1 (2021): 1-48

Website: https://journal.stiba.ac.id

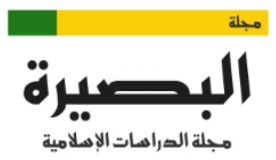

مجلة الصراهات الإهلامية

AL-BASHIRAH

تطبيقات القاعدة:

ا - لو طلق امرأته في مرض موته ثلاثا قاصدا حرماها من الميراث، ثمّ مات وهي في العدة

فإنّا ترث منه ردا لعمله و عقوبة برد عمله هذا عليه وحرمانه ثمرته بتوريثها منه(YIr).

r - "الفارّ من الزّكاة قبل تمام الحول بتنقيص النّصاب أو إخراجه عن ملكه بتحب عليه الزّكاة

ولو صرف أكثر أمواله في ملك ما لا زكاة فيه كالعقار والحليّ فهل ينزل منزلة الفارّ: على

وجه8ين" (rIT)

ب- فيما يتعلق بأحكام الآخرة: فإن "المتعجّل للمحظور يعاقب بالحرمان، فمن ترك شيئا

لله هواه نفسه عوّضه الله خيرا منه في الدّنيا والآخرة" (عاب).

الخاتمة

قد توصل الباحثان من خلال البحث ما يلي :

ا ـ أنه من خلال استخراج القواعد المتعلقة بالنيات والمقاصد من كتاب "طرح التثريب" للحافظ العراقي وابنه الحافظ أبي زرعة -رحمهما الله- تبين مدى فقه هذين الإمامين الجليلين، وأنه لا تنحصر في جانب من الجوانب الفقهية، بل هو شامل في فروعها وأصولها.

ب. أن النيات والمقاصد لها منزلتها وأهميتها في الشريعة الإسلامية. فهي روح العمل وأساسها؛ فلا عمل

إلا بالنية، وكل عمل يرتبط ارتباطا وثيقا بنيته وقصده في وقوع آثاره وتبيعاته. فلذلك النية بحاجة إلى

ما يضبطها ويرشد طريقها؛ وذلك يتمثل في وجود تلك القواعد الفقهية الضابطة لها. r. أنه تم الوقوف على عشرة قواعد في النيات والقصد من خلال كتاب "طرح التثريب" للحافظ العراقي وابنه؛ وهذا العدد ليس حصرا لما، فإنه قد ينفتح للإخوة الباحثين الآخرين ما لا ينفتح لكاتب هذا البحث من القواعد المتعلقة بموضوع النية والقصد.

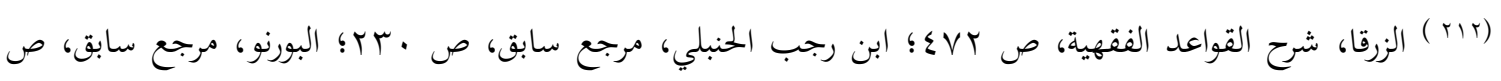

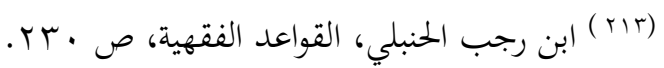

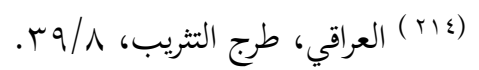




\section{البصيرة: مجلة الار اسات الإسلامية \\ AL-BASHIRAH: JOURNAL OF ISLAMIC STUDIES \\ Vol. 2 No. 1 (2021): 1-48}

Website: https://journal.stiba.ac.id

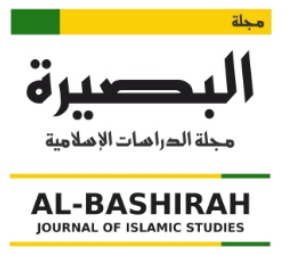

قائمة المراجع

'Abdu al-Karīm, al-Duktūr Aḥmad Ma'bad. Al-Hāfiz al- 'Irāqū wa aśaruhu fì al-Sunnah. Al-Ṭab ah: 1. Al-Riyāḍ: maktabah aḍwā al-Salaf, 2004

Abū 'Abdi al-Raḥmān al-Jazā'irī, 'Abdu al-Majīd Jum'ah. Al-Qawā id al-Fiqhiyah alMustakhrajah min kitāb i ' lām al-muwaqqi ìn. Al-Ṭab ah: I. Al-Dammām: dār ibni al-Qayyim wa dār ibni 'affān, 2002

Al-Āmidī, abu al-Hasan sayyid al-Dīn 'al̄̄ bin ab̄̄ 'al̄̄ bin Muhammad bin Sālim al-ṡa 'labī, (taḥqīq: 'Abdu al-Razzāq 'Afîfī). Al-Iḥkām fì uṣūl al-Aḥkām. Bīrūt: al-Maktab alIslāmī

Al-Asyqar, al-Duktūr 'Umar Sulaimān. Maqāṣid al-Mukallafìn fì mā yata 'abbad bihi lirabbi al- 'Álamīn (au al-Niyāt fì al- 'Ibàddāt). Al-Ṭab'ah: I. Al-Kuwait: maktabah al-Falāḥ, 1981

'Azizah 'Akwasy, (risālah mājistīr). Al-Qawa'̄̃ wa al-Dawābit al-Fiqhiyah alMustakhlaṣah min kitāb ușul al-Futyā lī al-Imām ibni Hāriś al-Khusyan̄̄. AlJazā'ir: jāmi 'ah al-Jazā'ir, 2001

Al-Bagawī, Abū Muḥammad al-Husain bin Mas'ūd, (taḥqīq: Muḥammad 'Abdullāh alNamr wa Ākharūn). Ma àlim al-Tanzīl fì tafsīr al-Qurān. Al-Ṭab'ah: IV. AlRiyāụ: dār țaibah, 1996

Al-Bāḥisīn, al-Duktūr Ya 'qūb bin 'Abdi al-Wahhāb. Qā'idah al-Umūr bimaqāṣidiha; dirāsah nazariyah wa ta'șiliyah. Al-Ṭab'ah: I. Al-Riyāḍ: maktabah al-Rusyd, 1998

Al-Bāḥisīn, al-Duktūr Ya'qūb bin 'Abdi al-Wahhāb. Al-Mufașṣal fì al-Qawāid alFiqhiyah. Al-Ṭab'ah: II. Al-Riyāẹ: dār al-Tadmuriyah

Barnāwī, Halīmah bintu Hasan, (risālah muqaddamah linā̄l darajah al-Mājistīr). AlQawā id wa al-Dawābit al-Fiqhiyah 'inda syaikh al-Islām ibn taimiyah fì kitāb al-Zakāh wa al-Șaūm wa al-Hājj. Makkah al-Mukarramah: jāmi 'ah ummu alQurā, 1997

Al-bassām, Abū 'Abdi al-Raḥmān 'Abdullāh bin 'Abdi al-Raḥman bin Șāliḥ al-Tamīmī. Tauḍ̄h al-Aḥkām min bulūg al-Marām. Al-Ṭab ah: V. Makkah al-Mukarramah: maktabah al-Asadī, 2002

Al-Buhūtī, Manșūr bin Yūnus bin Șalāḥ al-Dīn. Kasysyāf al-Qannā' 'an matni al-Iqnā' . Bīrūt: dār al-Kutub al-'Ilmiyah

Al-Bukhārī, Muhammad bin Ismā '̂̃l, (tahqūq: Muhammad Zuhaīr bin Nāṣir al-Nāṣīr). AlJāmi 'al-Musnad al-Sahīh al-Mukhtașar min umūr rasūlillāh șallāllāh 'alaihi wa sallam wa sunanih wa ayyāmih. Al-Ṭab 'ah: I. al-Riyāḍ: dār țā̄q al-Najāh, 2001

Al-Burnū, Muḥammad Șidq̄i bin Aḥmad bin Muḥammad. Mausū'ah al-Qawā id alFiqhiyah. Al-Țab ah: I. Bīrūt: mu'assasah al-Risālah, 2003

Al-Burnū, al-Duktūr Muḥammad Șidqī bin Aḥmad Abū al-Ḥāris̀ al-Gazzī. Al-Wajīz fì ı̣̀̂ah qawā 'id al-Fiqh al-Kulliyah. Al-Ṭab 'ah: IV. Bīrūt: mu'assasah al-Risālah, 1995 


\section{البصيرة: مجلة الارسات الإسلامية \\ AL-BASHIRAH: JOURNAL OF ISLAMIC STUDIES \\ Vol. 2 No. 1 (2021): 1-48}

Website: https://journal.stiba.ac.id

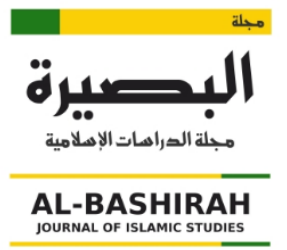

Al-Dausarī, al-Duktūr Muslim bin Muhammad bin Mājid. Al-Mumti' fì al-Qawā id alFiqhiyah. Al-Ṭab 'ah: I. al-Riyāḍ̣: dār zidn̄i, 2007

Al-Disūqī, Muḥammad bin Aḥmad bin 'Arafah al-Mālikī. Hāsyiah al-Disūqū 'alā alSyarh al-Kabīr. Bīrūt: dār al-Fikr, dūna sanah

Al-Fairūz Ābādī, Majd al-Dīn Abū Ṭāhir Muhammad bin Ya qūb. Al-Qāmūs al-Muhịṭt. Al-Ṭab'ah: VIIII. Bīrūt: mu'assah al-Risālah

Al-Fayūmī, Aḥmad bin Muḥammad bin 'Alī al-Hamawī al- 'Abbās. Al-Mașābīh al-Munīr fì garīb al-Syarh al-Kabīr. Duna țab ah. Bīrūt: al-Maktabah al-'Ilmiyah

Al-Hajjāwīe Abū al-Nujā Syaraf al-Dīn Mūsā bin Aḥmad bin Mūsā. Al-Iqnā’ liṭāib alIqnā'. Bīrūt: dār al-Ma rifah

Al-Isnawī, Jamāl al-Dīn 'Abdu al-Raḥīm bin Hasan. Nihāyah al-Saūl fì syarhi minhāj alWuṣūl. Miṣr: maṭba'ah muhammad 'alì șabīḥ, 1969

Ibnu Abī al-'Izzi al-Ḥanafì, Șadru al-Dīn Muhammad bin 'Alā al-Dīn 'Alī bin Muhammad, (taḥqīq: jamā'ah min al-'Ulamā, takhrīj: Nāṣir al-Dīn al-Albānī). Syarḥu al- 'Aqūdah al-Ṭaḥāwiyah. Al-Ṭab 'ah: I. Al-Qāhirah: dār al-Salām, 2005

Ibnu al-As̀īin, Abu al-Hasan 'Alī bin Abī al-Karam Muḥammad al-Syaibānī al-Jazarī. AlKāmil fì al-Tārīkh. Al-Ṭab ah: I. Bīrūt: dār șādir, 1965

Ibnu al-As̀īr, Majdu al-Dīn Abū al-Sa ādāt al-Mubārak al-Syaibānī al-Jazarī, (taḥqīq: Ṭāhir Aḥmad al-Zāwā wa Maḥmūd Muḥammad al-Ṭun̄ḥ̄i. Al-Nihāyah fí garīb alHadis wa al-Ajar. Bīrūt: al-Maktabah al-'Ilmiyah, 1979

Ibnu Tugrī Bardī, Abū al-Mahāàin Jamāl al-Dīn Yūsuf bin 'Abdillāh, (taḥīị: Fahīm Muhammad Syaltūt). Al-Dalīl al-Syāfì 'ala al-Munhal al-Ṣâfì. Al-Ṭab'ah: I. Makkah al-Mukarramah: markaz al-Baḥsì al-'Ilmī jāmi ah ummu al-Qurā, dūna sanah

Ibnu Tugrī Bardī, jamāl al-Dīn Yūsuf al-Atābikī. Al-Nujūm al-Zāhirah. Al-Ṭab'ah: I. Bīrūt: dār al-Kutub al-'Ilmiyah, 1997

Ibnu Taimiyah, Aḥmad bin 'Abdu al-Halīm al-Harrān̄̄, jam 'u wa tartīb: 'Abdu al-Raḥmān bin Qāsim wa ibnuhu Muḥammad. Majmū' al-Fatāwā. Al-Madīnah alNabawiyah: majma' al-Malik Fahd lițibā'ah al-Muṣḥaf al-Syarīf, 1995

Ibnu Hajar al- 'Asqalān̄̄, Aḥmad bin 'Alī bin Hajar Abū al-Faḍl, (Isyrāf: Muhib al-Dīn alKhatīb). Fatḥu al-Bārī syarḥu șah̄ịh al-Bukhārī. Al-Ṭab'ah: 1. Bīrūt: dār alMa'rifah, 1960

Ibnu Hazm, Abū Muḥammad 'Alī bin Aḥmad bin Sa '̄̄d al-Andalusī al-Qurțubī al-Zāhirī, (taḥqīq: Aḥmad Syākir). Al-Iḥkām fì Uṣūl al-Iḥkām. Bīrūt: dār al-Āfằq al-Jadīdah, dūna sanah

Ibnu Daqīq al- 'Īd, (taḥqīq: Aḥmad Muḥammad Syākir). Iḥkām al-Iḥkām syarh 'umdah alAḥkām. Al-Qāhirah: mațb ah al-Sunnah al-Muḥammadiyah, dūna sanah

Ibnu Rajab al-Hanbalī, 'Abdu al-Raḥmān bin Aḥmad. Al-Qawā'id al-Fiqhiyah. AlȚab ah: I. Bīrūt: dār al-Kutub al-'Ilmiyah, 1997 


\section{البصيرة: مجلة الارسات الإسلامية \\ AL-BASHIRAH: JOURNAL OF ISLAMIC STUDIES \\ Vol. 2 No. 1 (2021): 1-48}

Website: https://journal.stiba.ac.id

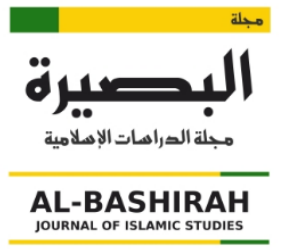

Ibnu Rusyd Abū al-Walīd Muhammad bin Aḥmad bin Muhammad bin Aḥmad al-Qurṭubī. Bidāyah al-Mujtahid wa nihāyah al-Muqtașid. Al-Qāhirah: dār al-Hadì̀, 2004

Al- 'Imrān̄̄, Abū al-Husain Yaḥyā bin Abī al-Khair bin Sālim al-Syāfi 'ī al-Yman̄̄, (i tinā: qāsim al-Nūrī). Al-Bayān fì mażhab al-Syāf $i$ 'ì. Al-Ṭab'ah: I. Juddah: dār alMinhāj, 2000

Al-'Īdrūs, Sayyid Naẓmi taufīq, (risālah mājistīr). Al-Hāfiz al- 'Irāqū Abū al-Faḍ 'Abdu al-Raḥim bin al-Husain wa manhajuhu fì kitābihi țarh al-tas்rīb. Al-Urdun: jāmi 'ah āli al-Bait al-Urduniyah

Al- '̄̃sā, al-Duktūr 'Abdullāh bin 'Īsā, (risālah duktūrah). Al-Qawā 'id al-Fiqhiyah fì bābai al-'Ibādāt wa al-Mu 'āmalāt min khilāli kitāb al-Mugnī lī al-Muwaffaq Ibni Qudāmah. Al-Riyāḍ: jāmi 'ah al-Imām Muhammad bin Su'ūd al-Islāmiyah, 1989

Ibnu Fahd, Muhammad bin Muhammad Abū al-Faḍl Taqī al-Dīn al-Hāsyimī al-`Alwī alUșfūnī ṡumma al-Makkì al-Syāfi '̄i. Lahzu al-Alhāz biżail țabaqāt al-Huffāz. AlTả 'ah: I. Bīrūt: dār al-Kutub al-'Ilmiyah, 1998

Ibnu Qudāmah, Abū Muhammad Muwaffaq al-Dīn 'Abdullāh bin Aḥmad bin Muhammad al-Jamā'il̄̄ al-Maqdisī, (tahqī̄: al-Duktūr 'Abdullāh bin 'Abdi al-Muḥsin alTurkī). Al-Mugnī. Al-Țab'ah: I. Al-Qāhirah: dār hijr

Ibnu al-Qayyim al-Jauziyah, Muḥammad bin Abī Bakr bin Ayyūb bin Sa d Syams al-Dīn, (tahqīq: Muhammad 'Abdu al-Salām Ibrāhīm). I' lām al-Muwaqqi 'ìn 'an rabbi al'Álamīn. Al-Ṭab 'ah: I. Bīrūt: dār al-Kutub al- 'Ilmiyah, 1991

Al-Juhan̄̄, Aḥmad bin Muḥammad, (risālah mājistīr). Al-Ārā al-Ușūliyah fí al-Muțlaq wa al-Muqayyad wa al-Manțūq wa al-Mafhūm lilhạfiz al-'Irāqī wa ibnihi fì kitābihima țarhu al-Taśrīb. Makkah al-Mukarramah: jāmi 'ah ummu al-Qurā, 1996

Al-Khasylān, Khālid bin Sa d bin Fahd. Al-Tadākhul baina al-Aḥkām fì al-Fiqh al-Islāmī. Al-Ṭab ah: I. Al-Riyāḍ: dār Isybīlia, 1998

Manșūr, al-Duktūr Muḥammad Khālid 'Abdu al-'Azīz. Al-Tadākhul wa asंaruhu fì alAḥkām al-Syar 'iyah. Al-Ṭab ah: I. Al-Urdun: dār al-Nafā'is, 1997

Al-Nawawī, Abū Zakariya Muḥyi al-Dīn Yaḥya bin Syaraf, (taḥqīq: Zuhair al-Syāwīsy). Rauḍh al-Tâlibīn wa 'umdah al-Muftīn. Al-Ṭab ah: III. Bīrūt: al-Maktab alIslāmīi, 1992

Al-Qaḥṭānī, Yāsir bin 'Alī bin Mas' ūd, (risālah mājistīr). Al-Qawà 'ìd wa al-Dawābit alFiqhiyah 'inda al-Imām Ibn Daqūq al- İd min khilāl kitābih "iḥ̄àm al-Aḥkām syarh 'umdah al-Aḥkām”' jam 'an wa dirāsatan. Makkah al-Mukarramah: jāmi 'ah ummu al-Qurā

Al-Qurțubī, Abū 'Abdillāh Muḥammad bin Aḥmad bin Abī Bakr bin Farh al-Anșārī, (taḥqīq: Aḥmad al-Bardūn̄̄ wa Ibrāhīm Ațfaisy). Al-Jāmi 'al-Aḥkām al-Qurān. AlȚab ah: II. Al-Qāhirah: dār al-Kutub al-Mișriyah, 1964

Al-Ramlī, Syams al-Dīn Muḥammad bin Abī al-'Abbās Aḥmad bin Hamzah Syihāb alDīn. Nihāyah al-Muḥtaj ilā syarḥi al-Minhāj. Bīrūt: dār al-Fikr, 1984

Al-Sa dān, al-Duktūr Muḥammad bin 'abdi al-Raḥmān bin 'Abdi al-'Azīz, (risālah duktūrah). Al-Qawā'id wa al-Ḍawābiț al-Fiqhiyah fì kitāb al-Mugnī lì ibni 


\section{البصيرة: مجلة الاراسات الإسلامية \\ AL-BASHIRAH: JOURNAL OF ISLAMIC STUDIES \\ Vol. 2 No. 1 (2021): 1-48}

Website: https://journal.stiba.ac.id

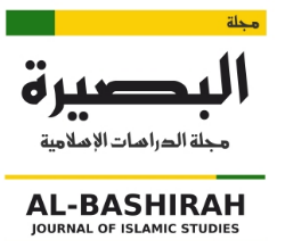

Qudāmah min awwali kitāb al-Hudūd wa hatā nihāyah kitāb al-Jizyah. Makkah al-Mukarramah: jāmi ah ummu al-Qurā, 2000

Al-Sūsī, al-Duktūr Muḥammad bin Yūnus, (maṭbū an bitaḥq̄i kitāb al-Umniyah fì idrāk al-Niyyah lī Syihāb al-Dīn al-Qurāfī). Majāl al-Niyyah fì al-Fiqh al-Islāmī. AlTab ah: I. Tūnus: dār sahnūn, 2010

Al-Syalāḥ̄, Khālid bin Ḍaifullāh. Al-Taqrīb fi takhrīj Aḥ̄àīis taqrīb al-Asānīd wa tartīb al-Masānīd. Al-Ṭab 'ah: I. Al-Riyāụ: dār al-Mu’ayyid

Al-Syīrāzī, Abū Isḥāq Ibrāhīm bin 'Alī bin Yūsuf. Al-Luma' fI uṣūl al-Fiqh. Al-Ṭab ah: I. Bīrūt: dār al-Kutub al-'Ilmiyah, 2003

Al-Tirmiżī, Abū 'Īsā Muḥammad bin 'Īsā bin Surah bin Mūsā bin al-Dahḥāk, (taḥqīq: Aḥmad Muhammad Syākir wa ākharūn). Sunan al-Tirmiż̄. Al-Ṭab ah: II. Miṣr: syarikah maktabah wa maṭba 'ah mușțafā al-Bābī al-Halabī, 1975

Wizārah al-Auqāf wa al-Syu'ūn al-Islāmiyah al-Kuwaitiyah. Al-Mausū 'ah al-Fiqhiyah alKuwaitiyah. Al-Ṭab 'ah: I. Al-Kuwait: dār al-Salāsil, 1984

Yāsīn, 'Ulya 'Alī Muhạmmad, (risālah mājistīr). Tasyrīk al-Niyyah fi al- 'Ibādāt fì al-Fiqh al-Islāmī. Nābils: jāmi ah al-Najaḥ al-Wațniyah, 2013

Al-Zuhaīlī, al-Duktūr Muḥammad Mușțafā. Al-Qawā id al-Fiqhiyah wa tațbīqātuha fì alMażāhib al-Arba'ah. Al-Ṭab ah: I. Dimasyq: dār al-Fikr, 2006

Al-Zarqā, Aḥmad bin Muhammad al-Zarqā. Syarḥu al-Qawā id al-Fiqhiyah. Al-Ṭab ah: IV. Dimasyq: dār al-Qalam, 1996

\section{المراجع من الشبكة العنكبوتية}

Hammād, al-Duktūr Hamzah 'Abdu al-Karīm. Manāhij al-Taṣnīf al-Mu 'ạșirah fì alQawā id al-Fiqhiyah. Maqālah mansyūrah fī maqi' al-Multaqā al-Fiqhī 'alā rābiṭ: http://www.feqhweb.com/vb/t1296.html

Al-Rukkābī, 'Ārif bin 'Iwaḍ. Al-Qā'idah al-Fiqhiyah: (man ta'ajjala syai'an qabla awānih 'ūqiba biḥirmānih) wa amsilah wa namāżij min al-Wāqi'. Maqālah mansyūrah fì: http://islamancient.com/play.php?catsmktba=2450

Al-Suqār, Munqiżbin Mạ̣mūd. Al-Takfìr wa dawābițh. Makkah al-Mukarramah: rābițah al-'Ālam al-Islāmī, duna sanah, șafhah: 9; mauqi' al-durar al-Saniyah, alMausū'ah al-'Aqadiyah, http://www.dorar.net/enc/aqadia/3235, tārīkh: 17 rabī al-Awwal $1437 \mathrm{H} / 28$ desember $2015 \mathrm{M}$ 